
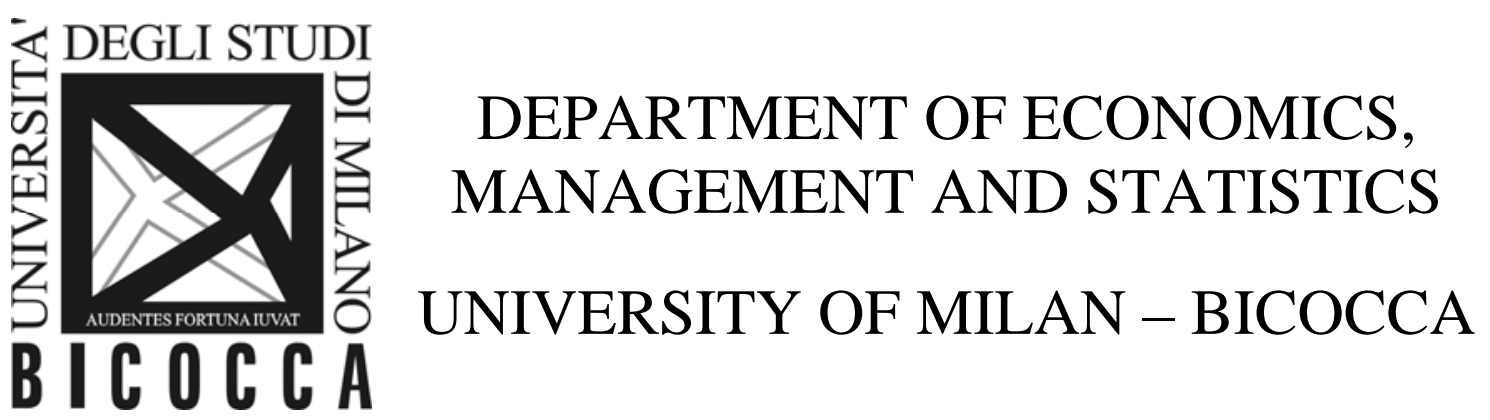

DEMS WORKING PAPER SERIES

Foreign exposure and heterogeneous performance of Italian firms: A survey of the empirical literature (1992-2014)

\author{
Valeria Gattai
}

No. 300 - April 2015

Dipartimento di Economia, Metodi Quantitativi e Strategie di Impresa Università degli Studi di Milano - Bicocca

http://dems.unimib.it/ 


\title{
Foreign exposure and heterogeneous performance of Italian firms: A survey of the empirical literature (1992-2014)
}

\author{
Valeria Gattai*
}

\begin{abstract}
This paper surveys 67 contributions on internationalisation and performance of Italian enterprises. It covers empirical studies (including working papers), published between 1992 and 2014, taking a microeconomic perspective and analysing the potential links between firms' global involvement and heterogeneity in economic, human capital and innovation and financial measures. The discussion is organised in an intuitive and non-technical way. At the same time, we devote particular attention to studying the different papers from many points of view, including their internationalisation measures, performance indicators, empirical approach, causality and results.
\end{abstract}

JEL: F1, F2, L2

Keywords: Internationalisation, Performance, Italy, Firm-level data, Survey

\footnotetext{
* Università di Milano-Bicocca, DEMS, Piazza Ateneo Nuovo 1, 20126 Milan (Italy), Tel: +39 0264483224, Fax: +39 0264483085, Email: valeria.gattai@unimib.it. The author is grateful to Piergiovanna Natale, Gianmarco Ottaviano and Les Oxley for useful comments and insightful discussions that greatly improved the quality and readability of the paper. Financial support from Università di Milano-Bicocca and MIUR (Italian Ministry of University and Education) are gratefully acknowledged. The usual disclaimer applies.
} 


\section{Introduction}

The last several decades have documented an impressive increase in firms' international involvement, drawing researchers' attention to the characteristics of international versus domestic enterprises.

Starting from the seminal contribution of Bernard and Jensen (1995), scholars around the world have begun to investigate the relationship between internationalisation and performance at the microeconomic level. They suggest that globally engaged enterprises tend to be a minority, compared with purely domestic players, but they perform better on a number of economic, human capital and innovation and financial indicators. This is some of the most striking evidence of the new millennium and it holds irrespective of the year and the country of the analysis.

While the first contributions mostly drew on US data, large longitudinal datasets have recently become available in Europe as well, which has triggered new academic research on the topic. Among European countries, Italy counts for an exceptionally wide range of firmlevel data sources and thus provides a privileged locus to test Bernard and Jensen's (1995) intuition. Moreover, since heterogeneity has become the keyword behind the burgeoning literature on internationalisation and performance, Italy is surely an interesting case study because it is characterised by several lines of heterogeneity. To mention just a few, consider the widely-documented gap between the North and the South, between urban and rural areas, between large high-tech conglomerates and small traditional firms (Bugamelli et al., 2001; Barba Navaretti et al., 2008). In a word, many different realities successfully coexist in the same country, pushing Melitz's (2003) assumption of firm-level heterogeneity to its very extremes. Yet, dozens of papers about internationalisation and performance of Italian enterprises have been written in the last 20 years across different fields of study - from International Economics to Industrial Organisation - all sharing the same microeconomic perspective and making use of firm-level information. This adds fresh evidence to the debate and provides very interesting findings. However, because most contributions are based on the same databases, the results are quite similar. Put another way, while many papers go over the same findings again and again, some important aspects are still ignored ${ }^{1}$.

In light of the above discussion, the present manuscript reviews all empirical ${ }^{2}$ studies (including working papers), published between 1992 and 2014, taking a microeconomic perspective and analysing the potential links between firms' global involvement and heterogeneity in economic, human capital and innovation and financial measures ${ }^{3}$.

\footnotetext{
${ }^{1}$ See Section 7 on this point.

${ }^{2}$ Some of the surveyed papers present a theoretical model, adding to the empirical analysis. For instance, using a simple short-run microeconomic model of export behaviour, Basile (2001a, b) show that export is positively correlated with firms' size, process innovation, group affiliation and the relative profitability of product innovation abroad and it is negatively correlated with firms' average labour cost and location in southern Italy. In a partially different framework, Becchetti and Gonzales (2001) model firms' export decision as a function of size and ownership structure, predicting that larger enterprises and those characterised by a lower degree of family ownership and higher number of controlling shareholders tend to export more. By extending Melitz's (2003) framework to endogenous product quality and non-iceberg transportation costs, Crinò and Epifani (2012) prove that the correlation between export intensity and productivity is negative in trade with lower income and/or distant countries. Finally, Razzolini and Vannoni (2009, 2011) combine the choice of export and subcontracting, deriving a clear productivity ranking across different categories of foreign involvement. As a result, firms that only export are the best performing, while firms that work only as subcontractors are the worst.

${ }^{3}$ Related issues, such as pricing-to-market strategies, are not covered here. The reader is referred to Bugamelli and Tedeschi (2007, 2008), Bugamelli et al. (2010), Bernard et al. (2010), Basile et al. (2012), Bernini and Tomasi (2014) for empirical studies on this topic.
} 
In doing so, our paper is intended to provide a critical survey about internationalisation and performance of Italian enterprises, namely a synthesis and an evaluation of the related literature. As a synthesis, it is suitable for scholars and practitioners in search of a comprehensive overview of the previous papers. As an evaluation, it should be of particular interest to those who wish to offer an original contribution and address the missing points of the existing studies. For these reasons, we try to keep a balance between a state-of-the-art description of past research and a list of suggestions about a tentative future agenda.

The discussion is organised in an intuitive and non-technical way to meet with the favour of a large audience. At the same time, we devote particular attention to analysing different papers from many points of view, including their internationalisation measures, performance indicators, empirical approach, causality and results. While the main text compares all 67 contributions on the basis of these issues, Table 1 focuses on one paper at a time. Therefore, we advise the reader to consider both parts together, to have a cross-literature overview first and in-depth analysis of the single contributions thereafter. To facilitate comparisons between Table 1 and the main text, we keep the same titles in the columns of the former and the sections of the latter.

One may argue that the single-country nature of this study prevents generalisation. Nonetheless, it should be noted that it favours comparability of results among the surveyed papers, getting rid of country specific factors. Moreover, this paper is structured to highlight not only results but also how results have been achieved using certain data, measures and empirical methodologies. For this reason, it should be interesting as a research agenda, independent of the reader's nationality. Scholars who wish to study the Italian economy might find some hints about the available data sources and the established results to differentiate their contribution from the existing literature. At the same time, scholars who wish to study a different country might benefit from reading about empirical measures and econometric tools to replicate the Italian exercise with a different sample of firms. We hope that the structure of the paper provides easy access to any reader's most interesting topic without necessarily going through the entire text.

Assuming that a single-country analysis is a worthwhile exercise, one might still cast some doubts on the choice of Italy as a case study. To be quite honest, there are several reasons why we think looking at Italy is interesting. First, as mentioned above, Italy is a country characterised by several lines of heterogeneity, which makes it a natural setting to investigate the topic. Second, as pointed out in Section 4, the country has a wide range of firm-level data sources to study the internationalisation-performance nexus from a multifaceted perspective. Third, there are many studies using Italian firm-level data, which somehow calls for a unifying framework ${ }^{4}$. Forth, as summarized in Section 6, Italy is highly internationalised, with a surprisingly large share of exporters and importers compared with the rest of the world. Fifth, Italian enterprises seem to learn from internationalisation and not simply self-select into the foreign markets; this is something unique to the Italian case that does not generally hold elsewhere. In light of the above discussion, we do believe there is a lot to learn from Italy.

In the authors' intention, this survey should carry some important differences compared with previous ones on related issues. On the one hand, we narrow the scope for research, delimiting more restrictively the literature of interest. As opposed to Helpman (2006) and Tybout (2003) who overview various developments in trade theories, our focus is more

\footnotetext{
${ }^{4}$ For a matter of comparison, the reader is referred to Wagner (2011) that provides a single-country survey of exports and firm characteristics in Germany. During the same decades, Wagner (2011) reviews 51 empirical studies on the topic. This suggests that the number of papers dealing with internationalization and performance of Italian enterprises is exceptionally high.
} 
specifically on the links between internationalisation and performance. Moreover, we restrict our attention to firm-level studies rather than reviewing both micro and macro contributions, as in Lopez (2005) and Singh (2010). Finally, we depart from Greenaway and Kneller (2007), Wagner (2007, 2012a) and Hayakawa et al. (2012) due to the single-country nature of the present study. On the other hand, having identified the topic more precisely, this paper offers a richer description of the literature and provides a greater number of details. For instance, we investigate all forms of international involvement, rather than focusing only on export (Wagner, 2007; Lopez, 2005), import (Singh, 2010) or foreign direct investment (FDI) (Greenaway and Kneller, 2007). We then cover all performance variables instead of restricting attention to productivity, as in Wagner (2007, 2012a), Lopez (2005), Singh (2010) and Hayakawa et al. (2012). Finally, we comment on more recent developments, which are quite relevant given the fast-growing nature of the literature of interest. In a recent paper, Bottasso and Piccardo (2013) review some empirical contributions dealing with the exportproductivity nexus of Italian manufacturing enterprises. Compared with them, we take a much broader perspective here because we consider both manufacturing and service firms, we analyse many internationalisation strategies, adding to export, and we include quite a broad array of performance measures, adding to productivity. Furthermore, Bottasso and Piccardo (2013) are mostly concerned with presenting the main findings from the surveyed papers, while our emphasis is more on the research process that delivered the final results than in results themselves. For all of these reasons, we believe this manuscript provides a complementary rather than an alternative picture with respect to existing studies.

The remainder of the paper is organised as follows. Sections 2 and 3 compare all internationalisation and performance measures. Section 4 describes the empirical approach of the different studies. Section 5 investigates causality issues, and Section 6 contains the main results. Section 7 presents the conclusions, suggests future lines of research and derives some policy implications.

\section{Internationalisation Measures}

This section is entirely devoted to internationalisation measures. In (2.1) we present all categories of international involvement considered in the existing literature; and in (2.2) we discuss the main comparison strategies to investigate heterogeneity in performance between international and domestic players.

\subsection{Categories of international involvement}

Taking advantage of the rich datasets available in Italy and described in (4.1), firms' international involvement is measured quite exhaustively throughout the literature. To facilitate comparisons among the different papers and understand the most widely used proxies, our discussion is organised as follows. First, we identify the main classes of international involvement and characterise their relative importance by looking at the number of contributions dealing with them. Second, for each category, we describe the available measures in detail.

- Export. It is the most widely used class of international involvement, appearing in 62 out of 67 contributions. It is considered both the only category of foreign exposure to study performance premium of exporters versus domestic enterprises, and together with import, two-way trading and FDI to see whether performance premium varies with different degrees of internationalisation. It is measured as export status (a dummy taking value 1 for exporters), status of "big exporters" (a dummy taking value 1 for "big exporters", namely firms exporting 
more than a certain threshold that may vary throughout the literature), status of exporters by geographical area (a dummy taking value 1 for firms exporting to a given geographical area that may vary throughout the literature), status of exporters of services, status of future exporters (dummy taking value 1 for firms planning to look for new export markets in the next two years), status of occasional exporters (a dummy taking value 1 for firms exporting in one or two years over a five-year period), status of systematic exporters (a dummy taking value 1 for firms exporting in at least three years over a five-year period), export value, export value per worker, export growth rate (growth rate of export value), export intensity (export over sales), number of destinations, number of exporters, number of exported goods, number of exported goods by destination, number of foreign clients, dummy for country dropping, dummy for product dropping, share of foreign sales from dropped countries and share of foreign sales from dropped products.

- FDI. It is the second most widely used category of foreign involvement, considered in 13 out of 67 contributions. It is always combined with other means of internationalisation, such as export, import, international outsourcing, foreign penetration operations, commercial or production partnerships and offshoring. It is measured as FDI status (a dummy taking value 1 for investors), status of production FDI (a dummy taking value 1 for investors in production FDI), status of commercial FDI (a dummy taking value 1 for investors in commercial FDI), number of investors and FDI intensity (percentage of firm's turnover from FDI).

- Import. The links between import and performance of Italian enterprises are analysed only in seven papers. Import is never considered alone, vis-à-vis with domestic operations, but always combined with export and two-way trading. It is measured as import status (a dummy taking value 1 for importers), number of imported goods, number of origins, status of importers by geographical area (a dummy taking value 1 for firms importing from a given geographical area) and status of "big importers" (a dummy taking value 1 for firms importing more than a certain threshold that may vary throughout the literature), status of importers of services and import intensity by geographical area (share of imported inputs from low- and high-income countries over sales).

- Offshoring. It is defined as firms' choice to carry out part of their production process in a foreign country whether internally or externally with respect to their boundaries ${ }^{5}$. Only five out of 44 contributions include offshoring and consider it alone or together with export and FDI. Offshoring is measured as offshoring status (a dummy taking value 1 for offshoring firms), status of offshoring firms of services, status of offshoring firms by geographical area (a dummy taking value 1 for firms offshoring to a given geographical area that may vary throughout the literature) and offshoring intensity by geographical area (share of imported inputs from low- and high-income countries over sales).

- Two-way trading. Most papers dealing with import also consider two-way trading to define foreign involvement of firms engaged both in import and in export. This enables authors to disentangle performance premium due to sole import, sole export, or the sum of the two, comparing players belonging to these classes among themselves and with domestic enterprises. Two-way trading is usually measured through a status variable (a dummy taking value 1 for firms engaged in import and export).

- Subcontracting. Subcontracting is an internationalisation mode that embraces all sales of articles which are ordered in advance and where marketing duties rest with the giver of the order (Sharpston, 1975). It involves two firms, namely a buyer and a seller. The seller can be

\footnotetext{
${ }^{5}$ Only a couple of papers specify which part of the production process has to be carried out in a foreign country to have offshoring. For instance, Crinò (2010) considers the transfer abroad of service activities, while Lo Turco and Maggioni (2012) deal with intermediates.
} 
either an Italian or a foreign enterprise, and the same is the case for the buyer. Notice also that subcontracting is considered both alone or together with export in the literature of interest. The available measures include subcontracting status and intensity.

- International partnerships. International partnerships denote a non-equity internationalisation mode involving commercial or production collaboration between Italian and foreign enterprises. They are considered only in two papers, compared with export and FDI. They are simply measured through the status of commercial partnerships and the status of production partnerships.

- International outsourcing. International outsourcing is defined as firms' choice to externalize part of their production process to an independent foreign enterprise. It appears only in one contribution, together with export and FDI. It is measured as international outsourcing intensity (percentage of a firm's turnover from international outsourcing) and the number of outsourcers.

- Foreign penetration operations. This label is employed in Basile et al. (2003) to gather various types of sales outlets, promotional initiatives and trade agreements. Foreign penetration operations are never considered alone as the only category of foreign involvement, but rather are combined with export and FDI. They are measured as foreign penetration operations status.

\subsection{Comparison strategy}

Having described all categories of international involvement, it is worth briefly discussing comparison strategies adopted in the literature.

We should remember that the main goal of the surveyed papers is to investigate potential links between internationalisation and performance of Italian enterprises. Therefore, identifying some categories of foreign exposure (as in 2.1) is the first step to study the performance differentials of global versus domestic enterprises. The second step then relates to the comparison strategy, namely the choice on how to compare performance of firms characterised by different degrees of internationalisation.

A careful review of the literature suggests that there are two main comparison strategies.

Those who opt for the first strategy build one variable for each class of foreign exposure and then compare global enterprises with themselves and with domestic players. Suppose, for instance, that a certain dataset contains information on export and FDI status. In this case, there would be one dummy for exporters and one for firms engaged in FDI. In the end, the authors would be able to compare the performance of exporters versus investors versus domestic players.

Those who opt for the second strategy consider, instead, one variable encompassing all categories of international exposure and build an index of increasing foreign involvement. In the previous example, there would be only one discrete variable combining export, FDI and domestic operations. The authors would then study how performance varies with changes in the values of the above mentioned index.

The large majority of the papers take the first perspective and only two of them choose the second. In particular, Basile et al. (2003) consider a foreign expansion index taking value 0 for domestic enterprises, 1 for exporters, 2 for firms engaged in export and foreign penetration operations and 3 for firms engaged in export, foreign penetration operations and FDI. This measure clearly reflects the idea that different internationalisation modes are complements rather than substitutes. Indeed, it is built according to a cumulative process in which each category incorporates the previous one. A similar view is taken by Benfratello and Razzolini 
(2009) where internationalisation is a discrete variable taking value 1 for domestic enterprises, 2 for firms engaged in export and 3 for firms engaged in export and FDI.

\section{Performance Indicators}

Performance indicators can be grouped into three main categories designated as economic, human capital and innovation and financial variables. In the following section, we characterise their relative importance and describe all the available measures.

\subsection{Economic}

Economic variables are the most widely used performance indicators in the literature of interest. They appear in 62 out of 67 papers and capture different aspects of firms' life and balance sheet details. Economic variables include:

- Size. It is proxied by the number of employees, number of white collar employees, number of blue collar employees, sales, growth rate of sales and sales per employee.

- Productivity. It is defined as labour productivity (value added per employee), growth rate of labour productivity and Total Factor Productivity (TFP), estimated through econometric procedures ${ }^{6}$.

- Wage. It is measured as average wage, wage of blue collar employees, wage of white collar employees and wage premium (wage of white collar employees over average wage).

- Age. It is defined as the difference between year $t$, when the analysis is set, and the year of foundation.

- Capital and capital intensity (capital per employee). They appear in numeric values.

- Gross operating margin. It appears in numeric value.

- Value added and value added per capital. They appear in numeric values.

- Investment in tangible assets. It appears in numeric values.

- International experience. It is defined as a dummy for past experience as an exporter, a dummy for the number of destinations, a dummy for the type of distribution channels, a dummy for executives working abroad, a dummy for commercial or technical collaboration with foreign enterprises and the number of foreign affiliates.

- Type of ownership and control. It is proxied by a dummy for family ownership, a dummy for foreign ownership, a dummy for the type of controlling party (individual, holding, institution and foreign control), the share of executives related to the family or individual who owns the firm and the number of controlling shareholders.

- Type of customers. It is defined as a dummy for selling to large companies, a dummy for selling to small and medium enterprises, a dummy for utilisation of external services and the percentage of sales to commercial agents or firms.

- Labour flexibility. It is measured by a dummy for firms employing any form of labour considered flexible by Italian law.

- District affiliation. It is proxied by a dummy for district affiliation.

- Group affiliation. It is defined as a dummy for group affiliation.

- Consortium affiliation. It is defined as a dummy for consortium affiliation.

- Survival probability. It is considered as a minimum performance requirement and defined as the difference between year $t$, when the analysis is set and the year of foundation plus 1 .

\subsection{Human capital and innovation}

\footnotetext{
${ }^{6}$ More details about TFP estimation can be found in Castellani and Giovannetti (2010) and Crinò and Epifani (2012), where several econometric techniques are compared.
} 
These variables characterise firms' endowment of intangible resources. They are the second most widely used performance indicators, appearing in 35 out of 67 contributions. They include:

- Human capital indicators, such as the share of white collar employees, the share of blue collar employees, the share of graduates, the share of permanent employees and the share of $\mathrm{R} \& \mathrm{D}$ personnel.

- Innovation variables, measured as Research \& Development (R\&D) investment, R\&D investment per employee, $R \& D$ investment over sales, internal $R \& D$ investment over sales, external $R \& D$ investment over sales, external $R \& D$ investment from collaboration with universities over sales, external R\&D investment from collaboration with other companies over sales, external R\&D investment from collaboration with other organisations over sales, investment in intangible assets, a dummy for R\&D investment, Information Technology (IT) investment per employee, Information \& Communication Technology (ICT) investment, a dummy for hardware investment, a dummy for software and TeLeCommunication (TLC) investment, a dummy for product innovation, a dummy for product or process innovation, a dummy for process or service innovation, a dummy for marketing innovation, a dummy for organisational innovation, a dummy for investment to reduce the use of raw materials, a dummy for investment to reduce the use of labour force, a dummy for investment to improve firm's product quality, a dummy for investment to improve firm's productivity, a dummy for technical collaboration with competitors/clients/suppliers, a dummy for investment to develop new products, a dummy for high tech firms (i.e. firms whose share of computer stock over total capital stock is above the median), a dummy for low tech firms (i.e. firms whose share of computer stock over total capital stock is below the median), the share of investment in innovative plants, the share of innovation costs due to purchase of innovation capital, the share of innovation costs due to purchase of engineering and pre-product development, the level of automation of the production process, a dummy for patent application, a dummy for firm's certification, the number of PC per employee, the number of years since the first ICT was adopted, the turnover from innovations, the level of technological avant-garde (computed as the mean of quality control, handling, design, storage and ICT), level of product innovation (computed as the mean of firms' ability to innovate product materials, functionality or design) and planned investment in innovation over the next five years.

\subsection{Financial}

Even though financial variables complete the picture regarding firms' performance, giving precious information on their health, they are studied in conjunction with the internationalisation of Italian enterprises only in nine papers.

Financial variables include:

- Return on Investment (ROI). It is measured as net profit over investment.

- Return on Sales (ROS). It is measured as net income over sales.

- Cash flow. It is defined as profits net of tax expenditures plus depreciation.

- Cash stock. It is measured as liquid assets plus cash flow.

- Number of banks. This variable tells how many banks the firm is in contact with.

- Strength of the relationship between the firm and its main bank. It is defined as firm's debt with its main bank over total assets.

- Liquidity ratio. It is measured as firm's current assets less current liabilities over total assets.

- Leverage ratio. It is defined as firm's ratio of total liabilities to equity.

- Weak credit rationing. It is a dummy taking value 1 if the firm would have liked to obtain more credit at the market interest rate. 
- Strong credit rationing. It is a dummy taking value 1 if the firm would have liked to obtain more credit at the market interest rate and demanded more credit than it actually obtained.

- Credit rating index. It is an index ranking firms in nine categories of credit worthiness from high-reliability to extremely high risk.

- Collateral. It is a dummy taking value 1 if the firm is usually asked for collateral and personal guarantees when applying for a loan.

- Euro introduction. It is defined as a dummy for Euro introduction.

\section{Empirical approach}

\subsection{Data}

All contributions covered in the present survey are based on firm-level longitudinal datasets, which differ in terms of type and source.

As for the type of data, out of 67 papers, 65 focus on the manufacturing sector and only two on the service sector (Conti et al., 2010a; b); moreover, 57 develop a single-country analysis, considering only Italian enterprises, and five take a cross-country perspective using different datasets for individual economies (ISGEP, 2008; Mayer and Ottaviano, 2008) or a single harmonic database encompassing multiple home markets (Barba Navaretti et al., 2011, 2012; Aristei and Franco, 2014).

As for the sources, there is a good deal of variety. While most studies rely only on one data source, some papers merge two to exploit complementarities in the available information (Castellani and Zanfei, 2007; Castellani and Giovannetti, 2008, 2010; Castellani et al., 2010; Giovannetti et al., 2009, 2013; Serti and Tomasi, 2008a, b, 2012; Serti et al., 2010; De Angelis et al., 2011; De Nardis and Pappalardo, 2009; Grazzi, 2012; ISGEP, 2008; Macis and Schivardi, 2012; Pappalardo and Vicarelli, 2012) or employ different sources alternatively as a robustness check for their empirical results (Barba Navaretti et al., 2007; Ferragina and Quintieri, 2001).

Next, we list all data sources from the most widely used to the least. The reader is referred to Table 1 for the exact matching between each paper and its respective data source.

- Mediocredito Centrale/ Capitalia. This is the main sample survey on Italian enterprises, carried out by a large banking institution on a periodical base. It contains both quantitative and qualitative information, ranging from balance sheet details to business, employment, innovation, management and internationalisation. Mediocredito Centrale/Capitalia data are employed alone in 38 papers, and combined with FDI information from ICE-Reprint database in four of the surveyed contributions.

- Micro + COE. Administered by ISTAT, the Italian National Statistical Office, Micro is a longitudinal dataset containing balance sheet information on Italian manufacturing firms. COE represents ISTAT's external trade register and it provides firm-level information on export and import over the 1990s. Six of the surveyed papers merge Micro with COE, deriving performance indicators from the former and internationalisation measures from the latter.

- EFIGE. This is a cross-country database containing ex-ante homogeneous data on France, Italy, Spain, Austria, Germany, Hungary and UK. It provides both qualitative and quantitative information on firms' structure, employment, investment, innovation and internationalisation on a cross-sectional base. Only three of the surveyed papers rely on EFIGE data.

- Prodcom + COE/ISAE. Administered by ISTAT, Prodcom is a longitudinal database containing micro data on manufactured goods in Italy, including the number of produced goods and the type of production. In the literature of interest, Prodcom data on performance 
are merged either with COE data on trade or with the ISAE (Institute for Studies and Economic Analysis) business survey on exporting firms.

- ASIA. Administered by ISTAT on a yearly base, the Archivio Statistico delle Imprese Attive (ASIA) provides information about localisation, total employment, legal structure and industry affiliation, adding to balance sheet details on corporate enterprises. ASIA data have been used both alone and together with COE data to study the internationalisationperformance nexus of Italian enterprises.

- Invind. The Invind database has been administered by the Bank of Italy since the early 1970s and it surveys manufacturing firms with more than 20 employees. Although the main focus of this census may vary from year to year, information on balance sheet items and export is always available. Invind data are used both alone and together with the Italian Social Security Institute (INPS) information on workers in the surveyed papers.

- Centrale dei bilanci. To the best of our knowledge, only two studies about internationalisation and performance of Italian enterprises rely on Centrale dei bilanci data. This is a large panel dataset, containing balance sheet and export details on borrowers belonging to the manufacturing sector.

- CIS + ELIOS. The Community Innovation Survey (CIS) is a survey administered by Eurostat and involving enterprises from all European countries to assess various aspects of firms' innovative behaviour and performance. The European Linkage and Ownership Structure (ELIOS) is a dataset developed by the University of Urbino to study export, productive FDI and commercial FDI for a sample of Italian manufacturing firms.

- Federmeccanica. The Federmeccanica database has a longitudinal nature, it captures approximately 2,400 enterprises and it covers only one industry, mechanics, within the manufacturing sector. Balance sheet information is very detailed, especially concerning employment and wages; on the contrary, the only information about internationalisation concerns export.

- Indagine Regione Marche. The Indagine Regione Marche cross-sectional dataset originates from a field study carried out as part of a research project funded by Regione Marche in 1996. It contains information on balance sheet items, innovation and export for a stratified sample of supplier dominated and specialised suppliers ${ }^{7}$.

- SDOE. The SDOE Archive by Infocamere is a longitudinal database containing balance sheet and internationalisation details for a sample of Italian exporters. All firms included in the sample are small and medium enterprises (SMEs), they belong to the manufacturing sector and they are located in the province of Bergamo.

- Services. Since 2008, the Bank of Italy collects firm-level data on international trade in services on a quarterly basis to compile the "services" item in the current account of Italy's balance of payments. The survey targets firms with sales larger than 70 million Euro for approximately 3,000 units every year.

- SISSI. The Statistical Information System on Enterprises (SISSI) is a database developed by ISTAT and combining information from four sources: the System on Accounts of Firms, the Survey on Technological Innovation of Industrial Enterprises, COE and ASIA. The result is a large panel of manufacturing firms with detailed information on balance sheet, innovation and export operations.

- Survey on technology, innovation and export in Friuli-Venezia Giulia. Designed specifically by a group of researchers, this survey covers a sample of small manufacturing firms located in Friulia-Venezia Giulia and active in the furniture, mechanics and electro-electronics sectors.

\footnotetext{
${ }^{7}$ See Bell and Pavitt (1993).
} 
Interviews based on a multiple choice questionnaire embrace a wide spectrum of topics ranging from international business to innovation, from firms' characteristics to technology.

- Indagine Tagliacarne. Exploited only by one of the surveyed papers, this dataset contains detailed information on a sample of small and medium enterprises in Italy. The survey design is very rich, including questions on balance sheet data, innovation and internationalisation.

\subsection{Empirical strategy}

By and large, the empirical strategy adopted in the different papers consists of a combination of descriptive statistics and econometric analysis to better explore the relationship between internationalisation and performance. The reader is referred to Table 1 for the exact matching between each paper and its empirical strategy.

As far as the econometric analysis is concerned, a distinction is worth making between parametric and non-parametric techniques.

Within the class of non-parametric techniques, Kolmogorov-Smirnov is the most widely used test to compare the performance of different groups of firms, typically international versus non-international players. More specifically, it can be defined as a test for stochastic dominance between different distributions. Let $F$ and $G$ denote the cumulative distribution functions of a performance indicator measured for international and non-international firms, respectively. Then, the first order stochastic dominance of $F$ relative to $G$ implies that $F(x)-$ $G(x)$ is less than or equal zero for all values of $x$, with strict inequality for some $x^{8}$. This test implicitly assumes that both distributions have the same shape but different means. However, when one needs to compare two distributions characterised by different shapes, considering the relative position of medians, modes or means, the Kolmogorov-Smirnov test may no longer be informative, as the meaning of these measures is likely to change with the nature of the underlying distributions. Under these circumstances, it is more useful to consider the Fligner-Policello test that does not require either equal shape or symmetry in the distributions to be compared. Within the Fligner-Policello framework, $F$ is said to dominate $G$ if $\operatorname{Prob}\left\{X_{F}\right.$ $>X_{G}>>1 / 2$, where $X_{F}$ and $X_{G}$ are the two respective realisations ${ }^{9}$. Out of 67 papers, only five address non-parametric techniques: Benfratello and Razzolini (2009) use the KolmogorovSmirnov test, Grazzi (2012) and Secchi et al. (2014) employ the Fligner-Policello test and Razzolini and Vannoni (2009, 2011) perform both.

Apart from these cases, in the rest of the literature, the empirical analysis relies on econometric regressions. Depending on data availability, most authors run cross-sectional regressions, while panel estimates appear only in a few contributions. The choice of the econometric models takes all sorts; in particular, discrete dependent variable models are quite common. More details are available in Table 1.

\section{Causality}

Having described the existing papers' internationalisation measures, performance indicators and empirical approach, it is worth briefly discussing causality issues.

\subsection{Direction}

Two alternative although not mutually exclusive hypotheses explain why firms engaged in international activities could perform better than domestic enterprises.

\footnotetext{
${ }^{8}$ For more details, see Delgado et al. (2002).

${ }^{9}$ For more details, see Fligner and Policello (1981).
} 
The first hypothesis, called self-selection (SS), suggests that causality runs from performance to internationalisation. According to this view, there are ex ante performance differences between firms that will become international and firms that will keep serving the domestic market. The theoretical foundation of SS can be traced back to Melitz (2003), which has become a key benchmark framework for analysing the intra-industry effects of international trade $^{10}$. Melitz (2003) is a dynamic industry equilibrium model with heterogeneous firms operating in Dixit-Stiglitz monopolistically competitive industries. Upon entry in the market, firms draw a productivity level from a known distribution. Because there are fixed costs to export, an endogenous productivity threshold then determines who exports and who does not. As the model shows, exposure to trade induces only the more productive firms to enter the export market and simultaneously forces the least productive firms to exit. The core Melitz model has recently been developed in various ways, giving rise to a well-established body of theories on heterogeneous firms and trade ${ }^{11}$. On the one hand, a number of papers extend the original framework to consider asymmetries between countries. Asymmetries of this sort may regard factor endowments (Bernard et al., 2007), the extent of competition (Melitz and Ottaviano, 2008) or the efficiency with which countries use their frontier technology (Falvey et al., 2004) $)^{12}$. On the other hand, a few contributions depart from the Melitz setting as to model the relation between productivity and FDI, rather than trade. Notably, Helpman et al. (2004) analyse self-selection of firms in the context of horizontal FDI, Head and Ries (2003) focus instead on vertical FDI. A common message from this theoretical literature is that there exists a causal relationship between productivity and foreign involvement, allowing only more productive firms to cross national borders with trade or foreign direct investment. This is because operating abroad involves additional costs related to transportation, marketing, human capital and production that provide a natural entry barrier to less successful firms. To be concise, we adopt the following notation:

Internationalization $=f($ Performance , Control $)$

Equation (1) says that, under the self-selection assumption, internationalisation is considered as a function of performance and control variables.

The second hypothesis, called learning-by-internationalisation (LI), postulates that causality runs the other way around, from internationalisation to performance. In this sense, ex post performance differences emerge as a result of firms' exposure to the international arena. To the best of our knowledge, the first formal treatment of LI is due to Clerides et al. (1998). To sort out the direction of causality between export and productivity, they set up a theoretical model in which managers face stochastic costs and foreign demand processes, and choose which periods to participate in foreign markets. Interestingly, in their model, there exist sunk start-up costs of selling abroad, since managers might research foreign demand and competition, establish marketing channels, and adjust their products to meet foreign tastes. Absent closed-form solutions, simulations reveal that firms significantly improve their relative productivity after they begin exporting, which clearly points to the existence of a learning process. Drawing on Clerides et al.’s (1998) intuition, more recent studies have

\footnotetext{
${ }^{10}$ We focus on Melitz (2003) because of its theoretical influence and empirical success. However, it is not the only model pointing to a causal link between export and productivity. Alternative approaches to modelling firm heterogeneity and trade are Yeaple (2005), Bernard et al. (2003), Jean (2002) and Bustos (2011).

${ }^{11}$ For a survey, see Redding (2011).

${ }^{12}$ Countries matter also in Bernard et al. (2010). They develop a general equilibrium model of multi-product and multi-destination firms in which heterogeneity is measured in terms of productivity and consumer taste. A key result of this model is that firms with the highest productivity start exporting, and products with the highest attributes are exported to the largest number of foreign markets; on the contrary, products characterised by the worst attributes are sold only domestically.
} 
worked out several channels though which LI is likely to materialise. First, by interacting with foreign competitors and customers, firms derive information about reducing costs and quality rising processes (De Loecker 2007); second, by operating abroad, firms increase their scale and become more efficient (Baldwin and Gu 2009); third, by competing in foreign markets, firms are strongly encouraged to invest in R\&D and innovate to keep pace with their rivals (Aw et al. 2011); forth, operating abroad helps correcting for credit constraints and weak institutional environment at home, so that exporting goods is equivalent to importing (access to) better institutions (Van Biesebroeck 2005). For all these reasons, globally engaged enterprises are expected to improve faster than domestic players, thus improving their performance $^{13}$. Consistent with (1), the following notation is employed:

Performance $=f($ Internationalization, Control $)$

Equation (2) says that, under the learning-by-internationalisation assumption, performance is considered as a function of internationalisation and control variables.

The great bulk of the surveyed papers make the self-selection hypothesis and run regressions accordingly; the econometric model is set as in (2) only in 21 out of 67 studies; lastly, Casaburi et al. (2007), Castellani (2002), Ferragina and Quintieri (2001), Imbruno (2008a), ISGEP (2008), Serti and Tomasi (2008a), De Nardis and Pappalardo (2009) and Forlani (2011) consider both sides of causality. At this stage, it is worth mentioning that this classification of papers is simply based on how econometric regressions are sketched, namely on the choice of internationalisation measures and performance indicators as regressor or regressand.

\subsection{Econometric tools}

While it is possible to identify the underlying assumption of SS or LI in all the surveyed papers, seeing whether the empirical model resembles (1) or (2), only a few contributions take causality issues as seriously as to employ sophisticated econometric tools to address them. In the rest of the literature, statistically significant coefficients are simply interpreted as a signal of correlation, rather than causality, independently from the regressor/regressand choice.

To properly assess the direction of causality, purely cross-sectional data are not appropriate. This is because they do not enable researchers to see whether certain performance outcomes precede or follow firms' international involvement. To provide conclusive evidence on this issue, one needs to consider the temporal dimension. Depending on data availability, the surveyed papers implement three broad strategies, including lagged variables, the study of performance dynamics, and an explicit test for causality. While the first two solutions do not necessarily imply the availability of panel data, the third one crucially relies on them. A brief description of each econometric tool is provided below.

- Lagged variables. Once lagged variables are introduced, equation (1) becomes:

Internationalization $_{i t}=f\left(\right.$ Performance $_{i(t-k)}$, Control $\left._{i t}\right) \quad i=1 . . n \quad k=1 . .(t-1)$

The intuition is straightforward. Under the self-selection assumption, to assert the effect of performance on internationalisation, foreign involvement of firm $i$ at time $t$ is regressed on

\footnotetext{
${ }^{13}$ Notice that de Nardis and Pappalardo (2009) highlight a mechanism other than LI that is compatible with the same direction of causality. Interestingly, they show that multi-product exporters tend to experience various forms of product switching as a reaction to the competitive international arena. Product switching, in turn, positively and significantly affects firms' performance given that resources are efficiently allocated within firms' boundaries. Their analysis can be thought of as an extreme extension of the Melitz's (2003) intuition since heterogeneity across firms brings about intra-industry adjustments in favour of more productive firms, and heterogeneity across products results in intra-firm adjustments in favour of more productive products.
} 
firm i's performance on a previous point in time, generically called $t$ - $k$, to correct for possible simultaneity bias.

Similarly, equation (2) becomes:

Performance $_{i t}=f\left(\right.$ Internationalization $_{i(t-k)}$, Control $\left._{i t}\right) \quad i=1 . . n \quad k=1 . .(t-1)$

In (2'), performance of firm $i$ at time $t$ is regressed on firm $i$ 's foreign involvement at $t-k$, to investigate potential effects of internationalisation on economic, human capital and innovation and financial variables. Lagged variables appear in Basile (2001 a, b), Bratti and Felice (2012), Castellani (2002), Sterlacchini (2001), Benfratello et al. (2014), D’Angelo (2012) and Secchi et al. (2013, 2014).

- Study of performance dynamics

Following Pavcnik (2002), Casaburi et al. (2007) report the evolution over time of a productivity index by industry, defined as TFP of a given firm minus TFP of mean industry productivity in the base year, as shown in Equation (3).

TFPindex $_{i t}=\left(y_{i t}-\hat{y}_{i t}\right)-\left(y_{j}-\hat{y}_{j}\right)=\operatorname{TFP}_{i t}-T_{F P} \quad i=1 . . n \quad j=1 . . m \quad t=1 . . l$

Consider, for example, firm $i$ belonging to industry $j$. The first parenthesis of Equation (3) displays the difference between the actual and the estimated value of firm i's output at year $t$; the second parenthesis displays the difference between the actual and the estimated value of the industry $j$ mean output in the base year. Drawing on this approach, Casaburi et al. (2007) aggregate individual TFP through a weighted average where weights are given by each firm's value-added share with respect to total value added in the same year. Indices are then normalised taking 1998 as a base year. The intuition for looking at performance dynamics is straightforward. If firms involved in international operations at time $t$ turn out to be outperforming in dynamic (adding to static) terms, namely from year $t$ on, evidence is in favour of a learning process according to which internationalisation affects performance. On the contrary, if the productivity dynamics of globally engaged enterprises is not any better than that of domestic players, then the self-selection argument receives empirical support.

- Explicit test for causality. According to Bernard and Jensen (1995), to perform a proper test for causality, it is crucial to compare the performance of firms that become international (designated international starters) versus firms that keep serving the domestic market during a given period of time. This strategy is followed by Ferragina and Quintieri (2001), Imbruno (2008a), ISGEP (2008), Serti and Tomasi (2008a, 2012) and Forlani (2011).

Under the SS hypothesis, better players become international. This means that we should expect to find significant differences in performance indicators between future international starters and future non-starters several years before some of them become international. Put another way, to correctly assess the self-selection argument, we need to check whether today's international starters were better performing than today's non-starters in the past when none of them operated abroad. Formally, the following model is estimated:

Performance $_{i t-k}=f\left(\right.$ Internationalization $_{i t}$, Control $\left._{i t-k}\right) \quad i=1 . . n \quad k=1 . .(t-1)$

In (1') all firms that did not internationalise between $t-k$ and $t-1$ are selected and the average difference in performance indicators in year $t-k$ between those firms that internationalised in $t$ and those that did not are computed.

To test the second hypothesis, namely that international involvement fosters performance, one needs to investigate post-entry differences in the growth rates of performance indicators between international starters and non-starters. A formal test thus compares firms that did not internationalise between $t-k$ and $t-1$, but did so in $t$ and at least a couple of years between $t+1$ and $t+k$ (the so called international starters) and firms that did not internationalise in any year between $t-k$ and $t+k$. The estimated equation is set as follows: 
Performance $_{i t+k}-$ Performance $_{i t+1}=f\left(\right.$ Internationalization $_{i t}$, $\left._{\text {Control }}{ }_{i t}\right) \quad i=1 . . n k=1 . .(t-1)$

The main drawback concerning Bernard and Jensen's (1995) approach is that it does not precisely identify the causal relationship between international activity and performance, because it is not possible to observe the performance of international firms in the so called counterfactual situation, i.e., in the event they would not have started operating abroad. Such an issue may be addressed under the so called treatment effect approach. This provides several econometric techniques to estimate the average causal effect, namely the causal effect of a treatment (usually defined by a binary variable) on an outcome variable of interest. Notably, these techniques allow econometricians to account for possible non-random selection criteria which might induce self-selection bias. Under the treatment effect approach, international firms are considered as "treated", so that the average treatment effect (ATE) and the average treatment effect on treated (ATT) can be defined as follows:

$$
\begin{aligned}
& A T E=E\left[Y_{1 i}-Y_{0 i}\right] \\
& A T T=E\left[Y_{1 i}-Y_{0 i} / D_{i}=1\right]
\end{aligned}
$$

Where $Y_{1 i}$ is the potential performance of firm $i$ if it were engaged in international business, $Y_{0 i}$ if it were not and $D_{i}$ is a dummy equal 1 if the firm is engaged in international business. Given this notation, ATE is the expected effect of internationalisation on a randomly drawn firm, while ATT is the expected effect of internationalisation on international players. At this stage, it is worth noting that estimating ATE and ATT properly requires us to overcome serious methodological problems because one cannot observe the outcome of the same firm if engaged in international business or not. The most common approach to address this issue is to apply some matching techniques, i.e., to work on two parallel samples, designated as "treated" and "control" groups. While the former is made up of international enterprises, the latter groups some firms that are similar to those belonging to the treated group in all pretreatment characteristics. Having identified the treated and control groups, ATE is then estimated by averaging the differences in outcomes between each treated firm and its most similar untreated one. Treated and untreated firms are usually matched through the propensity score matching approach (PSM), i.e., according to the probability of being engaged in international business, estimated on the whole sample, conditional on some observed pretreatment characteristics ${ }^{14}$.

To capture the self-selection mechanism, Morone et al. (2011) employ PSM having some performance variables in the treatment; differently, Conti et al. (2013), Serti and Tomasi (2008a) and Crinò (2010) consider some internationalisation measures in the treatment to account for potential LI effects.

\section{Results}

This section reviews the most important findings about internationalisation and performance of Italian enterprises. It is organised in three sub-sections: (6.1) identifies some common patterns across the surveyed papers, (6.2) comments the degree of internationalisation of the Italian economy and (6.3) summarises the main performance premiums or discounts related to foreign exposure. In this way, we intend to compare the Italian experience with the general wisdom, which holds that globally engaged enterprises are "the happy few". This famous label, appearing in Mayer and Ottaviano (2008), suggests that firms engaged in international

\footnotetext{
${ }^{14}$ For a comprehensive discussion of these techniques, see Becker and Ichino (2002), Caliendo and Hujer (2006), Caliendo and Kopeinig (2008) and Imbens and Wooldridge (2009).
} 
business tend to be a minority in their respective populations, but they enjoy a superior performance compared with domestic players.

\subsection{Common patterns}

To help the reader understand the analytical part of the surveyed papers, this section identifies some common patterns that hold across the different contributions. Our goal is simply to gain insight into the underlying models and to highlight the basic mechanisms that drive the empirical results. Papers are grouped according to our personal view of what is their main contribution to the literature. Although this implies some discretion by the authors ${ }^{15}$, we are quite confident that the large number of details provided in the previous sections enable the reader to build an alternative classification, if needed.

- Innovation. Many contributions address the relation between innovation and export activities using Italian data. The results are quite consistent across this sub-literature; however, papers differ for the emphasis placed on some methodological issues (Benfratello et al. 2013), measurement concerns (Nassimbeni, 2001; D’Angelo, 2012; Morone, 2011) or international background (Sterlacchini, 1999, 2001; Basile, 2001a, b; Castellani and Zanfei, 2007; Benfratello et al., 2009; Giovannetti et al., 2009; Bratti and Felice, 2012). The most robust finding in this group of papers is that innovation is positively correlated with international activities. Nonetheless, the exchange rate devaluation reduces the impact of technological competitiveness because it also allows non-innovating enterprises to enter foreign markets (Basile, 2001a, b). An interesting exception is Benfratello et al. (2009) who report a negative and significant effect of innovation on firms' willingness to offshore.

- Not only export. While most of the surveyed papers have a clear focus on export, a few contributions analyse the relationship between performance and other internationalisation strategies such as FDI (Benfratello and Razzolini, 2009; Castellani and Giovannetti, 2008, 2010; Giovannetti et al., 2013), offshoring (Casaburi et al., 2007) and subcontracting (Giunta and Scalera, 2007; Razzolini and Vannoni, 2009, 2011). In this context, Benfratello and Razzolini (2009), Castellani and Giovannetti (2008, 2010) and Casaburi et al. (2007) find a neat productivity ranking among firms characterised by different commitment to foreign markets, with domestic firms at the bottom, exporters in the middle and FDI makers at the top. Complementary evidence on subcontracting is due to Giunta and Scalera (2007) and Razzolini and Vannoni (2009, 2011); despite the different framework of the analysis, a robust finding across these studies is that there exists a subcontracting discount, rather than a premium, for Italian enterprises.

- Financial market. The existence of sunk costs associated with international activities has been widely recognised; however, less attention has been devoted to understanding how firms cover these costs. Forlani (2011) analyses the case of internal funding and shows that the export status and the number of destinations are influenced by the level of cash stock only for the constrained firms. Differently, Minetti and Zhu (2011), Frazzoni et al. (2011), Secchi et al. (2013, 2014) and Aristei and Franco (2014) focus on external funding. They report that the probability of exporting and/or importing is lower for rationed firms and that rationing reduces foreign trade; in addition, the role of entry costs differs according to the location of foreign markets and to the type of imported goods; moreover, the higher the share of firm's total assets financed through the main bank, the higher the probability of exporting and the larger the share of foreign sales over total sales; last but not least, financial constraints mostly determine price variations across exporting firms, with constrained firms charging higher

\footnotetext{
${ }^{15}$ This is because some contributions saddle on more than one pattern given their multifaceted nature.
} 
prices compared with unconstrained firms selling the same product to the same market. To complete the picture about internationalisation and financial markets, exchange rate regimes are considered in Pappalardo and Vicarelli (2012), Bugamelli and Infante (2003) and Basile et al. (2003), and financial variables such as profitability in Grazzi (2012). By and large, the single currency seems to have had a positive influence on the overall Italian export, while there is no clear evidence of superior performance by exporters in terms of profitability and growth rate.

- Structural features of the Italian economy. Under this label, we group a few policy reports discussing how internationalisation interacts with some structural features of the Italian economy. They range from comparative advantages (Barba Navaretti et al., 2007) to sector specialisation (Barba Navaretti et al., 2007), from the North-South gap (Bugamelli et al., 2000, 2001; Barba Navaretti et al., 2008) to attractiveness (Castellani, 2007; Barba Navaretti et al., 2008; Bugamelli and Gallo, 2013). Interestingly, the Italian performance on the world stage seems to be most driven by micro factors (Barba Navaretti et al., 2007; Castellani, 2007); size is positively correlated with all internationalisation measures (Bugamelli et al., 2000, 2001) and southern enterprises are far behind the rest of the country even though their gap has been decreasing over time (Barba Navaretti et al., 2008). Looking at very recent years, leading Italian exporters showed very strong performance before and during the financial crisis of 2008-2009. Indeed, they featured higher than average levels of productivity since 2007, they strengthened their presence abroad and invested more during the pre-crisis years and they successfully managed to keep employment levels stable (Bugamelli and Gallo 2013).

- District affiliation and SMEs. A distinctive feature of the Italian economy is the pervasive presence of SMEs and industrial districts. Not surprisingly, the internationalisationperformance nexus is also analysed with respect to these issues. In particular, Becchetti and Rossi (2000) and Becchetti et al. (2010) deal specifically with district affiliation, while Campanini and Falzoni (2001), Becchetti and Gonzales (2001) and Bonaccorsi (1992) are more concerned with SMEs. Estimates due to Becchetti and Rossi (2000), Becchetti and Gonzales (2001) and Becchetti et al. (2010) reveal that externalities and economies of scale are actually at play in the provision of export services, meaning that the geographical agglomeration of SMEs in a delimited area significantly improves their export probability and intensity. In a partially different framework, Campanini and Falzoni (2001) report that firms exporting high shares of their sales are just a minority; moreover, export turns out to be positively and significantly correlated with the international experience, while it is not affected by size and innovation. To complete the picture about size premium, Bonaccorsi (1992) falsifies the general wisdom according to which firms' employment is positively correlated with their export intensity because Italian SMEs do exhibit high export over sales ratios.

- Labour market. This group embraces a few papers dealing with the potential consequences of internationalisation on the labour market, considering the effects of foreign exposure on wages (Serti et al., 2010; Macis and Schivardi, 2012; Manasse and Stanca, 2006; Manasse et al., 2004), employment (Crinò, 2010; Lo Turco and Maggioni, 2012) and skill composition (Crinò, 2010; Serti et al., 2010; Manasse and Stanca, 2006; Manasse et al., 2004; Piva and Vivarelli, 2001). In Serti et al. (2010), exporters are shown to pay higher wages and employ more skilled workers than non-exporters; moreover, wages and employment structures of trading firms vary a lot by country of destination and country of origin of trade flows. Adding to this, Crinò (2010) finds that the transfer of service activities abroad has no impact on the 
number of employees, while it changes their composition in favour of high skilled workers ${ }^{16}$ and Lo Turco and Maggioni (2012) document a negative effect of import of intermediates from low-income countries on local employment ${ }^{17}$. In a partially different framework, Macis and Schivardi (2012) show that export intensity positively affects wages and that higher wages paid by exporters are the joint result of the skilled composition and rent sharing effects. Complementary evidence is reported in Manasse and Stanca (2006) and Manasse et al. (2004) that prove that demand changes associated with trade have moved employment away from skill intensive firms, contributing to moderate the change in relative factor prices. Lastly, Piva and Vivarelli (2001) suggest that the increased demand for skilled workers over the 1990s is the result of organisational changes, rather than innovation and FDI.

- The import-export nexus. A common pattern across the following papers is that they identify unconventional links between import and export activities. This is either because import and export are treated as complementary activities (Serti and Tomasi, 2008b, 2012; Castellani et al., 2010) or because one is assumed to cause the other (Conti et al., 2013). Taking advantage of a rich database, Serti and Tomasi (2008b) and Castellani (2010) introduce quite a comprehensive taxonomy of traders, designated as only importers, only exporters and twoway traders. They show that two-way traders outperform only exporters and only importers. In a companion paper, Serti and Tomasi (2012) complement previous findings by showing that trade premiums are market specific and depend on some macroeconomic variables, such as geographical distance and the level of development. In a different framework, Conti et al. (2013) find that import per se does not drive firm-level performance but it enhances export which is, instead, responsible for the productivity premium through the usual LI mechanism.

- Causal links between export and productivity. In the following, we group a few papers sharing a common interest in the causal links between export and productivity. Some of them find support to both sides of causality (Serti and Tomasi, 2008a; Castellani, 2002), others to self-selection only (Ferragina and Quintieri, 2001; Imbruno, 2008a, b). In particular, Castellani (2002) finds that productivity does not affect firms' export status, but it positively affects their export intensity; moreover, export intensity exerts a positive impact on productivity, while export status does not. Complementary evidence on a wider spectrum of firm-level characteristics is provided by Serti and Tomasi (2008a). On the contrary, the explicit tests for causality run by Ferragina and Quintieri (2001) and Imbruno (2008a, b) cast support only in favour of self-selection, documenting the existence of pre-, rather than postentry effects of productivity on export.

- Italy vis-à-vis the rest of the world. Under his label, we group a few contributions dealing with the internationalisation-performance nexus from a cross-country perspective. Some of them employ European data (Mayer and Ottaviano, 2008, Barba Navaretti et al., 2011, 2012), others consider a broader geographical area (ISGEP, 2008); some draw on ex-post

\footnotetext{
${ }^{16}$ The effects of international trade on labour market outcomes are also analysed in Accetturo et al. (2013) at the industry level. Notably, they show that exports cause a sizeable skill upgrading in the local labour force by increasing the average level of education of the workforce and the share of white collars. Although this paper complements other contributions on the links between internationalisation and labour market outcomes, it is not covered in detail because it provides no empirical evidence at the micro level.

${ }^{17}$ In a contemporaneous paper, Lo Turco et al. (2013) study the relationship between offshoring and job stability in Italy in the period 1995-2001 by using an administrative dataset on manufacturing workers. International fragmentation of production is shown to negatively affect job stability. Interestingly, service offshoring and material purchases from developed countries foster job-to-job transitions of all workers and white collar employees within the manufacturing sector. On the contrary, material offshoring to low-income countries drives blue collar workers out of manufacturing. We do not cover this paper in detail since internationalisation measures are based on industry- rather than firm-level data, so it goes beyond the scope of the present survey.
} 
comparable datasets (Mayer and Ottaviano, 2008; ISGEP, 2008), others build on ex ante homogeneous information (Barba Navaretti et al., 2011, 2012). Nonetheless, a common feature of these contributions is that they allow for comparisons between Italy and the rest of the world. Notably, the case of Italy is peculiar because international players are the majority (Mayer and Ottaviano, 2008), there is evidence in favour of learning-by-internationalisation (ISGEP, 2008), and the country exhibits a higher percentage of international outsourcers compared with other European economies (Barba Navaretti et al., 2011). Moreover, some variables that exert a negative effect on internationalisation elsewhere become positive and statistically significant determinants of export when interacted with a dummy for Italy ${ }^{18}$ (Barba Navaretti et al., 2012).

- Service. While most of the surveyed papers address manufacturing operations, only a few contributions focus on services. For the sake of clarity, it is worth specifying that some of them actually analyse the internationalisation-performance nexus using data on service traders (Conti et al., 2010a, b), while others analyse trade of services by manufacturers (Federico and Tosti, 2012). In this context, Conti et al. (2010a, b) suggest that the international success of service enterprises is mostly related to their affiliation to national and international networks, age and relationship with large industrial firms; on the contrary, a higher level of productivity and higher skill intensity matter only in the case of export to more distant high-income countries. In a different framework, Federico and Tosti (2012) find that trade of services is highly concentrated in a handful of firms to whom large size and productivity premium accrue.

- The object of trade. Most of the surveyed papers associate performance differentials with heterogeneity in international status; nonetheless, a few contributions also dissect international status by the object of international operations. This allows for a deeper characterisation of trade premiums, according to the number of traded goods (De Angelis et al., 2011; De Nardis and Pappalardo, 2009) or the quality of the exported products (Crinò and Epifani, 2012). In particular, De Angelis et al. (2011) show that multi-product exporters are pervasive, and they account for the largest share of Italian aggregate export. Drawing on the same framework, De Nardis and Pappalardo (2009) find a positive correlation between product switching ${ }^{19}$, size and productivity, showing that exposure to foreign trade brings about intra-firm adding to intra-industry reallocation of resources towards more productive items. A different perspective on the object of trade is offered by Crinò and Epifani (2012). In their model, the elasticity of export intensity to productivity is proved to be increasing in per capita income of foreign destinations; econometric results are in line with these theoretical expectations.

\subsection{Degree of internationalisation}

Most of the surveyed papers (44) present empirical evidence on the degree of internationalisation of the Italian economy. This results from the intersection between the so called intensive and extensive margins of internationalisation (Mayer and Ottaviano, 2008). The extensive margin tells how many firms are engaged in global operations, while the

\footnotetext{
${ }^{18}$ This is the case of ownership structure and management practices.

${ }^{19}$ This notion of "product switching" differs from that of "product dropping" adopted in De Nardis and Ventura (2010) because it covers both the case of dropping and adding new products. Notice also that De Nardis and Ventura (2010) do not really study the links between internationalisation and performance, but rather ask whether product dropping has an impact on productivity for a sub-sample of Italian exporters. Hence, the causal relation, if any, involves product dropping and productivity and not product dropping and internationalisation. For this reason, we do not survey De Nardis and Ventura (2010), while we focus on De Nardis and Pappalardo (2009).
} 
intensive margin says how much these players are actually involved in international business according to different parameters such as the number of markets, the number of goods, the volume of trade, the percentage of trade, etc.

Intensive and extensive margins vary by category of foreign involvement.

For instance, exporters seem to be the majority of Italian enterprises. Depending on the dataset, they account for $60 \%, 65 \%, 67 \%, 69 \%$ or $75 \%$ of the entire population ${ }^{20}$. The results change slightly if we dissect data by historical period, intensity, industry and geographical area. Indeed, Bugamelli and Infante (2003) document that exporters were the minority during the 1980s, but they became the majority one decade later. Conti et al. (2010 a, b) find that exporters of services are just 24\% of the entire population. Furthermore, in studies by Campanini and Falzoni (2001), Castellani et al. (2010) and Mayer and Ottaviano (2008), "big"21 exporters are shown to be the minority of Italian enterprises. Finally, Barba Navaretti et al. (2008) report that export in southern Italy is more concentrated than in northern Italy. Broadly speaking, export seems to be highly concentrated, given that a small group of leading traders is responsible for a large amount of trade (Casaburi et al., 2007; Castellani et al., 2010; ISGEP, 2008; Mayer and Ottaviano, 2008).

Empirical evidence about import and two-way trading resembles evidence on export because both activities involve more than $50 \%$ of Italian firms and they are clearly controlled by a small number of big players (Serti and Tomasi, 2008b, 2012; Serti et al., 2010).

Results are quite different if we look instead at foreign direct investment. Depending on the dataset, firms engaged in FDI turn out to be only $6 \%, 8 \%, 9 \%, 10 \%$ or $11 \%$ of the entire population (Barba Navaretti et al, 2011; Bugamelli et al., 2000, 2001; Casaburi et al., 2007; Castellani and Giovannetti, 2008, 2010; Giovannetti et al., 2009, 2013) and the same is the case for international partnerships (Bugamelli et al., 2000, 2001), offshoring (Casaburi et al., 2007) and international outsourcing (Barba Navaretti et al., 2011).

Finally, a few papers simply report that Italian firms exposed to international business of any type are the majority, without distinguishing by category of foreign involvement (Basile et al., 2003; Benfratello and Razzolini, 2009; Castellani and Zanfei, 2007) ${ }^{22}$.

To conclude, Italian actors moving in the international stage are not "few" at all, which stands at odds with the overall picture of Lopez (2005), Wagner (2007), Greenaway and Kneller (2007) and Singh (2010). Although they are not few, one might still wonder if they are "happy". The following sub-section summarises the primary findings concerning this issue.

\subsection{Performance premiums/discounts}

The great bulk of the literature emphasises the existence of performance premiums related to the foreign exposure of Italian enterprises, which means that globally engaged firms are "happy", namely, they turn out to be better than domestic enterprises on a number of economic, human capital and innovation and financial variables. This finding holds irrespective of the data and the causality direction, running from internationalisation to performance or the other way around.

Only a few studies (8) identify performance discounts related to foreign involvement. For instance, Benfratello et al. (2009) show that more investment in innovation is associated with less offshoring; Bugamelli and Infante (2003) find that the average wage has a negative

\footnotetext{
${ }^{20}$ According to ICE (2013), exporters are only about 4\% of the total number of enterprises in Italy. The higher percentages documented in the surveyed literature probably depend on the characteristics of the respective samples. For more information on the data sources, please refer to Section 4.1.

${ }^{21}$ See Section 2 for a definition of "big exporters".

${ }^{22}$ In this case, results are probably driven by the massive presence of exporters in the respective datasets.
} 
impact on firms' probability to export; age is negatively correlated with production partnerships in Bugamelli et al. (2000, 2001); productivity is negatively correlated with subcontracting in Giunta and Scalera (2007) and Razzolini and Vannoni (2009, 2011); productivity is negatively correlated with export intensity to low-income destinations and not correlated with export intensity to high-income destinations in Crinò and Epifani (2012) ${ }^{23}$.

Those who believe that globally engaged enterprises are happy usually make two types of arguments. First, for each category of foreign involvement, they show that firms belonging to that specific class are better than domestic players. This is the case with export, import, twoway trading, FDI, international outsourcing, offshoring, foreign penetration operations, subcontracting and international partnerships. Second, a few papers encompassing multiple categories of foreign involvement identify a clear performance ranking for players with different degrees of internationalisation. For instance, Benfratello and Razzolini (2009) find that the productivity of firms engaged in export and FDI is higher than the productivity of exporters, which is higher than the productivity of domestic players. Casaburi et al. (2007) show that offshoring firms of final goods are more productive than offshoring firms of inputs and exporters. Castellani and Zanfei (2007) prove that firms engaged in production FDI are more productive and innovative than firms engaged in commercial FDI which, in turn, are more productive than exporters. In Serti and Tomasi (2008b, 2012), Castellani et al. (2010) and Serti et al. (2010), two-way traders are better than importers which, in turn, are better than exporters based on all performance indicators. Finally, in Mayer and Ottaviano (2008) and Castellani and Giovannetti (2008, 2010), firms engaged in FDI are more productive than exporters which, in turn, are more productive than domestic players. To summarise, Italian firms operating abroad are "happy", meaning that they benefit from various premiums related to international business. Moreover, the deeper the firm's commitment to foreign markets, the larger its premiums are. More details are available in Table 1.

\section{Conclusions}

This manuscript surveys a large number of contributions on internationalisation and performance of Italian enterprises, taking a microeconomic view and making use of firm-level data. 67 papers are carefully analysed according to a multifaceted perspective that takes into account their internationalisation measures, performance indicators, empirical approach, causality and results. This section summarises what we learn from Italy, it derives some policy implications and it sets forth future lines of research.

While heterogeneity is surely the keyword underlying the theoretical and empirical contributions surveyed here, our personal feeling is that some papers have been more successful than others in applying this concept. From the authors' point of view, recent studies offering a deep dissection of trade are particularly promising because they do not simply distinguish between import and export operations; rather, they go to the very details of each status, providing an extreme extension of Melitz's (2003) intuition. For instance, this is the case of Serti and Tomasi (2008b, 2012), Serti et al. (2010), Castellani et al. (2010), Conti et al. (2010a, b, 2013), Lo Turco and Maggioni (2012) and Aristei and Franco (2014) who dissect trade flows by origin and destination, offering interesting insights about the interaction between firm- and country-level factors. It is also the case of De Angelis et al. (2011) and De

\footnotetext{
${ }^{23}$ Grazzi (2012) does not find a performance discount for firms engaged in export activities; however, he documents the absence of any premiums related to profitability and growth rate. Similar results are reported in Piva and Vivarelli (2001) where the increased demand for skilled workers over the 1990s is the result of organisational changes rather than innovation and FDI.
} 
Nardis and Pappalardo (2009) who dissect trade flows by the number of traded goods, thus unveiling performance differentials between mono- and multi-product enterprises. Lastly, it is the case of Federico and Tosti (2012) and Casaburi et al. (2007) who define trade status according to the type of imported and exported products; this allows trade premiums by the object of import and export operations to be detected. A common feature of the above mentioned papers is that heterogeneity is accounted for in all the multifaceted nature of foreign transactions, which provides a much broader overview on the links between firms' foreign exposure and their economic outcomes.

Reading through the 67 papers dealing with internationalisation and performance of Italian enterprises has been extremely interesting and fascinating from the authors' point of view. It was also a useful exercise to highlight some robust findings that can be summarised under three main results. First, Italian firms engaged in international business are the majority. This is not obvious given the well-known abundance of small and medium enterprises. Despite their small scale, local firms do show a sophisticated international attitude. Second, Italian firms involved in foreign operations turn out to perform better than their domestic counterparts on a number of economic, human capital and innovation and financial variables. This means that there exists a strong correlation between internationalisation and performance. Third, there is evidence both in favour of self-selection and learning-byinternationalisation. Put another way, better Italian firms tend to operate abroad but, at the same time, operating abroad is likely to foster their economic performance. While readers should be familiar with the second result, which is quite established in the international debate, they would probably be surprised by the first and the third arguments that somehow contradict the general wisdom. Indeed, contrary to the rest of the world, there are more globally engaged Italian enterprises than not (6.2); moreover, contrary to their foreign counterparts, Italian firms learn from the international arena and do not simply self-select into the export market (6.3).

While these findings might be biased by the data employed in the empirical analysis, they still point to the existence of an "Italian case" that deserves more attention. How? On the one hand, the present survey might encourage further research on the topic, suggesting a tentative future agenda. On the other hand, it could stimulate the current debate, deriving some policy implications inspired by the Italian case.

As far as the tentative future research agenda is concerned, our personal view is that scholars could undertake three main actions to improve on the existing literature. The first type of improvement concerns the data; the second involves the empirical strategy; and the third concerns the topic itself.

Improving on the data requires access to some original information. One problem with the existing studies is that most of them rely on the same data source. This means that the results are quite alike, with dozens of papers repeatedly addressing the same findings. Unfortunately, we are not aware of any new dataset to address the internationalisation-performance nexus apart from those described in (4.1). Unless primary information is collected by means of case studies or survey interviews, few improvements can be made with respect to the data.

Improving on the empirical strategy requires some original techniques to be employed instead. For instance, our survey reveals that OLS and discrete-dependent variable models are used very commonly to study the links between internationalisation and performance. On the contrary, propensity score matching and quintile regressions turn out to be new and relatively unexplored techniques that could deliver very interesting findings with respect to causality. To the best of our knowledge, PSM is applied only in three out of the 67 papers and quantile regressions only in one. Moreover, both techniques are used only to study trade premiums. 
Hence, the same empirical framework could easily be extended to the case of FDI or other internationalisation strategies using databases that are already available. Notice also that other recent empirical methods - including generalized propensity score matching and robust methods to deal with extremely heterogeneous firms or outliers ${ }^{24}$ - have not been employed yet to the Italian case. It goes without saying that it would be extremely challenging to confront these techniques with the available data.

Lastly, improving on the topic means to seriously reconsider what has been accomplished so far and what is still missing. Hopefully, our survey delivers some suggestions also with respect to this issue. For instance, a quick inspection of Table 1 reveals that most papers concern trade. Nonetheless, a deep dissection of trade is still missing even though the available databases allow for it. For example, further dissection of imports and exports by object of trade is possible using the Capitalia information on firms' trade in goods, services and both. This would allow for study of systemic performance differences among exporters (importers) of goods, services and both, thus replicating the empirical analysis of Ariu (2014) for Belgium, Walter and Dell'mour (2010) for Austria, Kelle and Kleinert (2010) for Germany and Breinlich and Criscuolo (2011) for the UK. Another possibility is to focus on foreign direct investment, rather than trade. Given that FDI has received little attention so far, our suggestion is to replicate some mechanisms that have already been applied to study the export/import premiums. For instance, to the best of our knowledge, foreign direct investment has not been dissected yet by geographical area despite the wealth of information provided by the ICE-Reprint database. Even a rough classification of host countries as developed and developing economies would be sufficient to replicate the analysis of Aw and Lee (2008) on Taiwanese enterprises. Furthermore, foreign direct investment could also be dissected by the percentage of foreign ownership, distinguishing between joint-ventures and wholly-owned enterprises. As put forward in Raff et al. (2008) for Japan, there might be some performance differentials between foreign investors operating under full versus partial ownership. Taking advantage of the ICE-Reprint database, the same empirical exercise could be performed using Italian firm-level data. Last but not least, we believe that additional effort should be exerted in studying potential correlations among different internationalisation strategies. We should recall from (6.1) that Lo Turco and Maggioni (2013) document a causal link running from import to export. Their intuition is that firms' internationalisation is characterised by sunk costs, some of which could be common between imports and exports. An easy extension of this framework consists in allowing for mutual causal effects between import and export operations, using the same data. This would provide comparable evidence with respect to Aristei et al. (2013) who consider both sides of causality but focus on a sample of eastern European and central Asian countries. It should also be noted that some of the channels underlying the import-export nexus may also hold in the case of trade and FDI, but this topic has not been explored yet.

As far as policy implications are concerned, the single-country nature of the present survey should deliver more targeted suggestions compared with multiple-country analyses.

Broadly speaking, there is wide consensus on the fact that promoting internationalisation and fostering economic performance are two desirable outcomes of the policymaking process. The literature on internationalisation and performance derives several interesting facts that help translate these theoretical goals into practical actions.

The first fact points to the existence of strong links between internationalisation and performance; given that they are highly interconnected phenomena, they should not be treated

\footnotetext{
${ }^{24}$ See Wagner (2012b) for a practical guide on the implementation of these techniques.
} 
in isolation as two separate goals, but rather addressed in a joint framework. A distinctive feature of Italy is that both the self-selection and the learning-by-internationalisation hypothesis are supported by the data. This greatly increases the set of available policy instruments. Suppose, for instance, that fostering internationalisation is judged to be of primary importance by the Italian government. Such a goal could be addressed either directly with measures that are likely to increase foreign exposure of Italian enterprises ${ }^{25}$ or indirectly by improving economic performance. Indeed, the SS mechanism ensures that better Italian firms self-select into the world stage ${ }^{26}$.

The second fact relates to the unit of analysis, namely the class of actors to which policy intervention could eventually be targeted. As stressed in Mayer and Ottaviano (2008), trade is a matter of firms rather than countries, i.e., that aggregated country-level volumes of import, export, FDI etc. are the result of disaggregated firm-level contributions. Hence, specific forms intervention, if agreed upon, should be targeted to firms, not designed at the industry or country level. At this stage, it is worth noting that firms' heterogeneity is extremely challenging from a policy perspective; if properly treated, it allows for successful implementation of targeted programs. However, any mistake in identifying the right target could translate into a risky waste of money. Drawing on the empirical evidence reviewed in this paper, a few suggestions are summarised below. For instance, support should be given to potential rather than actual international players because Italian firms are shown to improve their performance before entering into the foreign markets, which is consistent with the SS hypothesis. Put another way, successful internationalisation should be much more about increasing the number of firms involved than about increasing the involvement of already active firms. Indeed, Italian trade is shown to be highly concentrated, with a small group of leading companies being responsible for a large amount of foreign sales. Supporting potential international players and making them enter the club of leading enterprises would enable the country to improve its performance on the world stage. What type of intervention could deliver such an outcome? Based on the common patterns identified in (6.1), support should primarily favour firms' access to credit, innovative capacity, size expansion and productivity improvements, with a special focus on reducing the gap between the northern and southern parts of the country. All of these actions are likely to improve firm-level performance and, due to self-selection, boost internationalisation. The good news is that internationalisation will further improve firm-level performance through learning-by-internationalisation. Hence, once a virtuous process of this sort has been started, returns are expected to materialise for many years through the cumulative causation mechanism channelled by SS and LI. For all of these reasons, we strongly believe it is worth starting, and it is worth starting soon.

\footnotetext{
${ }^{25}$ This is the case, for instance, of export promotion policies.

${ }^{26}$ In doing this, particular attention should be devoted to detecting instances of conscious self-selection, i.e., the decision by which certain firms purposefully increase their productivity with the clear intention of becoming exporters and benefiting from export promotion policies (Lopez 2005).
} 
Table 1: Internationalisation measures, performance indicators, empirical approach, causality and results in the surveyed papers.

\begin{tabular}{|c|c|c|c|c|c|}
\hline 1. Study & $\begin{array}{l}\text { 2. Internationalisation } \\
\text { measures }\end{array}$ & 3. Performance indicators & 4.Empirical approach & 5. Causality & 6. Results \\
\hline $\begin{array}{l}\text { Aristei and Franco } \\
\text { (2014) }\end{array}$ & $\begin{array}{l}\text { 2.1 Categories of } \\
\text { international involvement: } \\
\text { - export (status; status of } \\
\text { exporter to the EU; intensity) } \\
\text { - import (status; status of } \\
\text { exporter from the EU; intensity) } \\
\text { - two-way trading (status) } \\
\text { 2.2 Comparison strategy: } \\
\text { One variable for each category, } \\
\text { to compare international } \\
\text { enterprises with themselves } \\
\text { and with domestic players. }\end{array}$ & $\begin{array}{l}\text { 3.1 Economic: } \\
\text { - size (employees) } \\
\text { - age } \\
\text { - group affiliation } \\
\text { 3.2 Human capital and } \\
\text { innovation: } \\
\text { - share of R\&D employees } \\
\text { - share of graduates } \\
\text { - R\&D investment } \\
\text { - dummy for product/process } \\
\text { innovation } \\
\text { 3.3 Financial: } \\
\text { - strong credit rationing } \\
\text { - weak credit rationing } \\
\text { - collateral } \\
\text { - strength of the relationship } \\
\text { between the firm and its main } \\
\text { bank }\end{array}$ & $\begin{array}{l}\text { 4.1 Data: } \\
\text { - Type: manufacturing sector, } \\
\text { cross-country analysis (Austria, } \\
\text { France, Germany, Hungary, } \\
\text { Italy, Spain, UK) } \\
\text { - Source: EFIGE (2008) } \\
\text { 4.2 Empirical strategy: } \\
\text { - Descriptive statistics } \\
\text { - Econometric analysis: } \\
\text { regressions (cross-section: } \\
\text { Probit, Bivariate Probit, } \\
\text { fractional regression approach) }\end{array}$ & $\begin{array}{l}\text { 5.1 Direction: } \\
\text { - self-selection } \\
\text { 5.2 Econometric tools: } \\
\text { none }\end{array}$ & $\begin{array}{l}\text { 6.1 Common patterns } \\
\text { Financial market } \\
\text { 6.2 Degree of } \\
\text { internationalisation: } \\
\text { Exporters are the majority } \\
\text { (64\%). } \\
\text { 6.3 Performance } \\
\text { premiums/discounts: } \\
\text { Credit rationing negatively } \\
\text { affects trade status and } \\
\text { intensity. Conditional on trading } \\
\text { in the EU, rationing does not } \\
\text { prevent firms from entering } \\
\text { additional importing and } \\
\text { exporting markets. However, } \\
\text { two-way traders are negatively } \\
\text { affected by financial constraints } \\
\text { when they access non-EU } \\
\text { markets. }\end{array}$ \\
\hline $\begin{array}{l}\text { Barba Navaretti et al. } \\
(2007)\end{array}$ & $\begin{array}{l}\text { 2.1 Categories of } \\
\text { international involvement: } \\
\text { - export (growth rate; status; } \\
\text { status of "big exporters", i.e., } \\
\text { firms exporting more than } 40 \% \\
\text { of sales in more than } 3 \\
\text { countries) } \\
2.2 \text { Comparison strategy: } \\
\text { One variable for each category, } \\
\text { to compare international } \\
\text { enterprises with themselves } \\
\text { and with domestic players. }\end{array}$ & $\begin{array}{l}\text { 3.1 Economic: } \\
\text { - size (employees, sales) } \\
\text { - age } \\
\text { - productivity (TFP) } \\
\text { - type of ownership \& control } \\
\text { (dummy for the type of } \\
\text { controlling party: individual, } \\
\text { holding, institution, foreign } \\
\text { control) } \\
\text { 3.2 Human capital and } \\
\text { innovation: } \\
\text { - share of white collar } \\
\text { employees } \\
\text { - share of blue collar } \\
\text { employees } \\
\text { - share of R\&D personnel } \\
\text { - n. of PC per employee } \\
\text { - years since first ICT was } \\
\text { adopted } \\
\text { - dummy for R\&D investment } \\
\text { 3.3 Financial: } \\
\text { none }\end{array}$ & $\begin{array}{l}\text { 4.1 Data: } \\
\text { - Type: manufacturing sector, } \\
\text { single-country analysis } \\
\text { - Source: Capitalia (2001- } \\
\text { 2003); Invind (2000-2005) } \\
\text { 4.2 Empirical strategy: } \\
\text { - Descriptive statistics } \\
\text { - Econometric analysis: } \\
\text { regressions (cross-section: } \\
\text { OLS, Probit, Ordered Probit) }\end{array}$ & $\begin{array}{l}\text { 5.1 Direction: } \\
\text { - self-selection } \\
\text { 5.2 Econometric tools: } \\
\text { none }\end{array}$ & $\begin{array}{l}\text { 6.1 Common patterns } \\
\text { Structural features of the Italian } \\
\text { economy } \\
6.2 \text { Degree of } \\
\text { internationalisation: } \\
\text { Exporters are the majority } \\
\text { (75\%). } \\
6.3 \text { Performance } \\
\text { premiums/discounts: } \\
\text { Big exporters are older, larger } \\
\text { and more productive; they enjoy } \\
\text { more investments in R\&D, more } \\
\text { foreign control and a higher } \\
\text { share of white collar employees } \\
\text { and R\&D personnel than firms } \\
\text { with less exposure to export. }\end{array}$ \\
\hline
\end{tabular}




\begin{tabular}{|c|c|c|c|c|c|}
\hline $\begin{array}{l}\text { Barba Navaretti et al. } \\
(2008)\end{array}$ & $\begin{array}{l}\text { 2.1 Categories of } \\
\text { international involvement: } \\
\text { - export (status; status of "big } \\
\text { exporters", i.e., firms exporting } \\
\text { more than } 40 \% \text { of sales in } \\
\text { more than } 3 \text { countries) } \\
\text { 2.2 Comparison strategy: } \\
\text { One variable for each category, } \\
\text { to compare international } \\
\text { enterprises with themselves } \\
\text { and with domestic players. }\end{array}$ & $\begin{array}{l}\text { 3.1 Economic: } \\
\text { - size (employees) } \\
\text { - age } \\
\text { - productivity (TFP) } \\
\text { 3.2 Human capital and } \\
\text { innovation: } \\
\text { - share of blue collar } \\
\text { employees } \\
\text { - share of graduates } \\
\text { - share of R\&D personnel } \\
\text { - dummy for R\&D investment } \\
\text { 3.3 Financial: } \\
\text { none }\end{array}$ & $\begin{array}{l}\text { 4.1 Data: } \\
\text { - Type: manufacturing sector, } \\
\text { single-country analysis } \\
\text { - Source: Capitalia (2001- } \\
\text { 2003) } \\
\text { 4.2 Empirical strategy: } \\
\text { - Descriptive statistics } \\
\text { - Econometric analysis: } \\
\text { regressions (cross-section: } \\
\text { Probit) }\end{array}$ & $\begin{array}{l}\text { 5.1 Direction: } \\
\text { - self-selection } \\
\text { 5.2 Econometric tools: } \\
\text { none }\end{array}$ & $\begin{array}{l}\text { 6.1 Common patterns } \\
\text { Structural features of the Italian } \\
\text { economy } \\
\text { 6.2 Degree of } \\
\text { internationalisation: } \\
\text { Export, in the South of Italy, is } \\
\text { more concentrated than in the } \\
\text { rest of the country. } \\
6.3 \text { Performance } \\
\text { premiums/discounts: } \\
\text { Big exporters are larger, older } \\
\text { and more productive and they } \\
\text { enjoy a higher share of } \\
\text { graduates and R\&D personnel, } \\
\text { a lower share of blue collar } \\
\text { employees and more R\&D } \\
\text { investment than firms with less } \\
\text { exposure to export. } \\
\text { Average values in the South are } \\
\text { lower than in the North, except } \\
\text { for TFP. Moreover, being } \\
\text { located in the South decreases } \\
\text { firms' probability of being a big } \\
\text { exporter. }\end{array}$ \\
\hline $\begin{array}{l}\text { Barba Navaretti et al. } \\
\text { (2011) }\end{array}$ & $\begin{array}{l}\text { 2.1 Categories of } \\
\text { international involvement: } \\
\text { - export (intensity; n. of } \\
\text { exporters; n. of destinations) } \\
\text { - FDI (intensity; n. of investors) } \\
\text { - international outsourcing } \\
\text { (intensity; n. of outsourcers) } \\
2.2 \text { Comparison strategy: } \\
\text { One variable for each category, } \\
\text { to compare international } \\
\text { enterprises with themselves } \\
\text { and with domestic players. }\end{array}$ & $\begin{array}{l}\text { 3.1 Economic: } \\
\text { - size (employees) } \\
\text { - productivity (labour } \\
\text { productivity) } \\
\text { 3.2 Human capital and } \\
\text { innovation: } \\
\text { - share of blue collar } \\
\text { employees } \\
\text { - share of graduates } \\
\text { - R\&D investment over sales } \\
\text { - dummy for product innovation } \\
\text { 3.3 Financial: } \\
\text { none }\end{array}$ & $\begin{array}{l}\text { 4.1 Data: } \\
\text { - Type: manufacturing sector, } \\
\text { cross-country analysis (Austria, } \\
\text { France, Germany, Hungary, } \\
\text { Italy, Spain, UK) } \\
\text { - Source: EFIGE (2008) } \\
\text { 4.2 Empirical strategy: } \\
\text { - Descriptive statistics } \\
\text { - Econometric analysis: } \\
\text { regressions (cross-section: } \\
\text { OLS, LPM) }\end{array}$ & $\begin{array}{l}\text { 5.1 Direction: } \\
\text { - self-selection } \\
\text { 5.2 Econometric tools: } \\
\text { none }\end{array}$ & $\begin{array}{l}\text { 6.1 Common patterns } \\
\text { Italy vis-à-vis with the rest of the } \\
\text { world } \\
\text { 6.2 Degree of } \\
\text { internationalisation: } \\
\text { Exporters are the majority } \\
\text { (75\%). Firms engaged in FDI or } \\
\text { international outsourcing are the } \\
\text { minority (6\%). } \\
6.3 \text { Performance } \\
\text { premiums/discounts: } \\
\text { The } n \text {. of exporters, investors } \\
\text { and outsourcers increases with } \\
\text { firms' size, productivity, human } \\
\text { capital and innovation. }\end{array}$ \\
\hline
\end{tabular}




\begin{tabular}{|c|c|c|c|c|c|}
\hline $\begin{array}{l}\text { Barba Navaretti et } \\
\text { al. }(2012)\end{array}$ & $\begin{array}{l}\text { 2.1 Categories of } \\
\text { international involvement: } \\
\text { - export (value; status; status of } \\
\text { exporters to China and India) } \\
\text { 2.2 Comparison strategy: } \\
\text { One variable for each category, } \\
\text { to compare international } \\
\text { enterprises with themselves } \\
\text { and with domestic players. }\end{array}$ & $\begin{array}{l}\text { 3.1 Economic: } \\
\text { - size (employees) } \\
\text { - productivity (labour } \\
\text { productivity) } \\
\text { - international experience } \\
\text { (dummy for executives working } \\
\text { abroad for at least one year) } \\
\text { - type of ownership \& control } \\
\text { (dummy for family ownership; } \\
\text { share of executives related to } \\
\text { the family/individual who owns } \\
\text { the firm) } \\
\text { 3.2 Human capital and } \\
\text { innovation: } \\
\text { none } \\
\text { 3.3 Financial: } \\
\text { none }\end{array}$ & $\begin{array}{l}\text { 4.1 Data: } \\
\text { - Type: manufacturing sector, } \\
\text { cross-country analysis (Austria, } \\
\text { France, Germany, Hungary, } \\
\text { Italy, Spain, UK) } \\
\text { - Source: EFIGE (2008) } \\
\text { 4.2 Empirical strategy: } \\
\text { - Descriptive statistics } \\
\text { - Econometric analysis: } \\
\text { regressions (cross-section: } \\
\text { Probit, OLS) }\end{array}$ & $\begin{array}{l}\text { 5.1 Direction: } \\
\text { - self-selection } \\
\text { 5.2 Econometric tools: } \\
\text { none }\end{array}$ & $\begin{array}{l}\text { 6.1 Common patterns } \\
\text { Italy vis-à-vis with the rest of the } \\
\text { world } \\
6.2 \text { Degree of } \\
\text { internationalisation: } \\
\text { none } \\
6.3 \text { Performance } \\
\text { premiums/discounts: } \\
\text { Exporters enjoy larger size, } \\
\text { productivity and international } \\
\text { experience, less centralized } \\
\text { control and family ownership } \\
\text { than non-exporters. } \\
\text { Within the group of exporters, } \\
\text { those selling to China and India } \\
\text { are the best performing. }\end{array}$ \\
\hline Basile (2001a, b) & $\begin{array}{l}\text { 2.1 Categories of } \\
\text { international involvement: } \\
\text { - export (status; intensity) } \\
2.2 \text { Comparison strategy: } \\
\text { One variable for each category, } \\
\text { to compare international } \\
\text { enterprises with themselves } \\
\text { and with domestic players. }\end{array}$ & $\begin{array}{l}\text { 3.1 Economic: } \\
\text { None } \\
\text { 3.2 Human capital and } \\
\text { innovation: } \\
\text { - dummy for product/process } \\
\text { innovation } \\
\text { - dummy for investment to } \\
\text { improve firm's product quality } \\
\text { - dummy for investment to } \\
\text { improve firm's productivity } \\
\text { - dummy for investment to } \\
\text { develop new products } \\
\text { - dummy for investment to } \\
\text { reduce the use of raw } \\
\text { materials } \\
\text { - dummy for investment to } \\
\text { reduce the use of labour force } \\
\text { 3.3 Financial: } \\
\text { none }\end{array}$ & $\begin{array}{l}\text { 4.1 Data: } \\
\text { - Type: manufacturing sector, } \\
\text { single-country analysis } \\
\text { - Source: Mediocredito } \\
\text { Centrale (1989-1991; 1992- } \\
\text { 1994; 1995-1997) } \\
\text { 4.2 Empirical strategy: } \\
\text { - Descriptive statistics } \\
\text { - Econometric analysis: } \\
\text { regressions (cross-section: } \\
\text { Probit, Tobit, Cragg model, } \\
\text { sample selection model) }\end{array}$ & $\begin{array}{l}\text { 5.1 Direction: } \\
\text { - self-selection } \\
\text { 5.2 Econometric tools: } \\
\text { - lagged variables }\end{array}$ & $\begin{array}{l}\text { 6.1 Common patterns } \\
\text { Innovation } \\
\text { 6.2 Degree of } \\
\text { internationalisation: } \\
\text { Exporters are the majority } \\
\text { (60\%). } \\
\text { 6.3 Performance } \\
\text { premiums/discounts: } \\
\text { Innovation is positively } \\
\text { correlated with export. } \\
\text { Innovation and export are less } \\
\text { pronounced in the South of Italy } \\
\text { than in the rest of the country. }\end{array}$ \\
\hline Basile et al. (2003) & $\begin{array}{l}\text { 2.1 Categories of } \\
\text { international involvement: } \\
\text {-export (status) } \\
\text { - foreign penetration operations } \\
\text { (status) } \\
\text { - FDI (status) } \\
2.2 \text { Comparison strategy: } \\
\text { One variable encompassing all } \\
\text { categories to build an index of } \\
\text { increasing foreign involvement. }\end{array}$ & $\begin{array}{l}\text { 3.1 Economic: } \\
\text { none } \\
\text { 3.2 Human capital and } \\
\text { innovation: } \\
\text { - dummy for product/process } \\
\text { innovation } \\
\text { - dummy for investments to } \\
\text { develop new products } \\
\text { - dummy for investments to } \\
\text { reduce the use of labour force } \\
\text { 3.3 Financial: } \\
\text { none }\end{array}$ & $\begin{array}{l}\text { 4.1 Data: } \\
\text { - Type: manufacturing sector, } \\
\text { single-country analysis } \\
\text { - Source: Mediocredito } \\
\text { Centrale (1989-1991; 1992- } \\
\text { 1994; 1995-1997) } \\
\text { 4.2 Empirical strategy: } \\
\text { - Descriptive statistics } \\
\text { - Econometric analysis: } \\
\text { regressions (cross-section: } \\
\text { Ordered Probit) }\end{array}$ & $\begin{array}{l}\text { 5.1 Direction: } \\
\text { - self-selection } \\
\text { 5.2 Econometric tools: } \\
\text { none }\end{array}$ & $\begin{array}{l}\text { 6.1 Common patterns } \\
\text { Financial market } \\
6.2 \text { Degree of } \\
\text { internationalisation: } \\
\text { Firms engaged in international } \\
\text { operations of any kind are the } \\
\text { majority of Italian enterprises. } \\
6.3 \text { Performance } \\
\text { premiums/discounts: } \\
\text { More foreign involvement is } \\
\text { associated with more innovative } \\
\text { effort. }\end{array}$ \\
\hline
\end{tabular}




\begin{tabular}{|c|c|c|c|c|c|}
\hline $\begin{array}{l}\text { Becchetti and Rossi } \\
(2000)\end{array}$ & $\begin{array}{l}\text { 2.1 Categories of } \\
\text { international involvement: } \\
\text { - export (status; intensity) } \\
2.2 \text { Comparison strategy: } \\
\text { One variable for each category, } \\
\text { to compare international } \\
\text { enterprises with themselves } \\
\text { and with domestic players. }\end{array}$ & $\begin{array}{l}\text { 3.1 Economic: } \\
\text { - district affiliation } \\
\text { 3.2 Human capital and } \\
\text { innovation: } \\
\text { none } \\
\text { 3.3 Financial: } \\
\text { none }\end{array}$ & $\begin{array}{l}\text { 4.1 Data: } \\
\text { - Type: manufacturing sector, } \\
\text { single-country analysis } \\
\text { - Source: Mediocredito } \\
\text { Centrale (1989-1991) } \\
\text { 4.2 Empirical strategy: } \\
\text { - Descriptive statistics } \\
\text { - Econometric analysis: } \\
\text { regressions (cross-section: } \\
\text { Probit, Tobit) }\end{array}$ & $\begin{array}{l}\text { 5.1 Direction: } \\
\text { - self-selection } \\
\text { 5.2 Econometric tools: } \\
\text { none }\end{array}$ & $\begin{array}{l}\text { 6.1 Common patterns } \\
\text { District affiliation and SMEs } \\
\text { 6.2 Degree of } \\
\text { internationalisation: } \\
\text { none } \\
6.3 \text { Performance } \\
\text { premiums/discounts: } \\
\text { Being located in a district has a } \\
\text { positive correlation with firms' } \\
\text { export probability and export } \\
\text { intensity. }\end{array}$ \\
\hline $\begin{array}{l}\text { Becchetti and } \\
\text { Gonzales (2001) }\end{array}$ & $\begin{array}{l}\text { 2.1 Categories of } \\
\text { international involvement: } \\
\text { - export (status; intensity) } \\
2.2 \text { Comparison strategy: } \\
\text { One variable for each category, } \\
\text { to compare international } \\
\text { enterprises with themselves } \\
\text { and with domestic players. }\end{array}$ & $\begin{array}{l}\text { 3.1 Economic: } \\
\text { - size (employees) } \\
\text { - type of ownership and control } \\
\text { (dummy for family ownership; } \\
\text { number of controlling } \\
\text { shareholders) } \\
\text { 3.2 Human capital and } \\
\text { innovation: } \\
\text { none } \\
\text { 3.3 Financial: } \\
\text { none }\end{array}$ & $\begin{array}{l}\text { 4.1 Data: } \\
\text { - Type: manufacturing sector, } \\
\text { single-country analysis } \\
\text { - Source: Mediocredito } \\
\text { Centrale (1992-1994) } \\
\text { 4.2 Empirical strategy: } \\
\text { - Descriptive statistics } \\
\text { - Econometric analysis: } \\
\text { regressions (cross-section : } \\
\text { Probit, Logit, Conditional log- } \\
\text { log, Tobit) }\end{array}$ & $\begin{array}{l}\text { 5.1 Direction: } \\
\text { - self-selection } \\
\text { 5.2 Econometric tools: } \\
\text { none }\end{array}$ & $\begin{array}{l}\text { 6.1 Common patterns } \\
\text { District affiliation and SMEs } \\
\text { 6.2 Degree of } \\
\text { internationalisation: } \\
\text { none } \\
\text { 6.3 Performance } \\
\text { premiums/discounts: } \\
\text { Firms' size is positively } \\
\text { correlated with the export } \\
\text { probability and intensity, while } \\
\text { family ownership and the } \\
\text { number of controlling } \\
\text { shareholders are negatively } \\
\text { correlated. }\end{array}$ \\
\hline $\begin{array}{l}\text { Becchetti et al. } \\
\text { (2010) }\end{array}$ & $\begin{array}{l}\text { 2.1 Categories of } \\
\text { international involvement: } \\
\text { - export (export value per } \\
\text { worker) } \\
2.2 \text { Comparison strategy: } \\
\text { One variable for each category, } \\
\text { to compare international } \\
\text { enterprises with themselves } \\
\text { and with domestic players. }\end{array}$ & $\begin{array}{l}\text { 3.1 Economic: } \\
\text { - district affiliation } \\
\text { 3.2 Human capital and } \\
\text { innovation: } \\
\text { none } \\
\text { 3.3 Financial: } \\
\text { none }\end{array}$ & $\begin{array}{l}\text { 4.1 Data: } \\
\text { - Type: manufacturing sector, } \\
\text { single-country analysis } \\
\text { - Source: ASIA (1998) } \\
\text { 4.2 Empirical strategy: } \\
\text { - Descriptive statistics } \\
\text { - Econometric analysis: } \\
\text { regressions (cross-section: } \\
\text { OLS) }\end{array}$ & $\begin{array}{l}\text { 5.1 Direction: } \\
\text { - self-selection } \\
\text { 5.2 Econometric tools: } \\
\text { none }\end{array}$ & $\begin{array}{l}\text { 6.1 Common patterns } \\
\text { District affiliation and SMEs } \\
6.2 \text { Degree of } \\
\text { internationalisation: } \\
\text { none } \\
6.3 \text { Performance } \\
\text { premiums/discounts: } \\
\text { There is a positive correlation } \\
\text { between district affiliation and } \\
\text { export of Italian firms operating } \\
\text { in three manufacturing sectors } \\
\text { (textile and textile products, } \\
\text { machinery and equipment } \\
\text { industry, and electrical apparel). }\end{array}$ \\
\hline $\begin{array}{l}\text { Benfratello and } \\
\text { Razzolini (2009) }\end{array}$ & $\begin{array}{l}\text { 2.1 Categories of } \\
\text { international involvement: } \\
\text { - export (status) } \\
\text { - FDI (status) } \\
\text { 2.2 Comparison strategy: } \\
\text { One variable encompassing all } \\
\text { categories to build an index of } \\
\text { increasing foreign involvement. }\end{array}$ & $\begin{array}{l}\text { 3.1 Economic: } \\
\text { - productivity (TFP) } \\
\text { 3.2 Human capital and } \\
\text { innovation: } \\
\text { none } \\
\text { 3.3 Financial: } \\
\text { none }\end{array}$ & $\begin{array}{l}\text { 4.1 Data: } \\
\text { - Type: manufacturing sector, } \\
\text { single-country analysis } \\
\text { - Source: Capitalia (2001- } \\
\text { 2003) } \\
\text { 4.2 Empirical strategy: } \\
\text { - Descriptive statistics } \\
\text { - Econometric analysis: } \\
\text { regressions (cross-section: } \\
\text { Multinomial Logit); non }\end{array}$ & $\begin{array}{l}\text { 5.1 Direction: } \\
\text { - self-selection } \\
\text { 5.2 Econometric tools: } \\
\text { none }\end{array}$ & $\begin{array}{l}\text { 6.1 Common patterns } \\
\text { Not only export } \\
6.2 \text { Degree of } \\
\text { internationalisation: } \\
\text { Firms engaged in international } \\
\text { operations of any kind are the } \\
\text { majority (75\%). } \\
6.3 \text { Performance } \\
\text { premiums/discounts: } \\
\text { Productivity of firms engaged in }\end{array}$ \\
\hline
\end{tabular}




\begin{tabular}{|c|c|c|c|c|c|}
\hline & & & $\begin{array}{l}\text { parametric analysis } \\
\text { (Kolmogorov-Smirnov) }\end{array}$ & & $\begin{array}{l}\text { export and FDI is higher than } \\
\text { productivity of exporters, which } \\
\text { is higher than productivity of } \\
\text { domestic players. }\end{array}$ \\
\hline $\begin{array}{l}\text { Benfratello et al. } \\
\text { (2009) }\end{array}$ & $\begin{array}{l}\text { 2.1 Categories of } \\
\text { international involvement: } \\
\text { - offshoring (status) } \\
\text { 2.2 Comparison strategy: } \\
\text { One variable for each category, } \\
\text { to compare international } \\
\text { enterprises with themselves } \\
\text { and with domestic players. }\end{array}$ & $\begin{array}{l}\text { 3.1 Economic: } \\
\text { none } \\
\text { 3.2 Human capital and } \\
\text { innovation: } \\
\text { - dummy for hardware } \\
\text { investment } \\
\text { - dummy for software and TLC } \\
\text { investment } \\
\text { 3.3 Financial: } \\
\text { none }\end{array}$ & $\begin{array}{l}\text { 4.1 Data: } \\
\text { - Type: manufacturing sector, } \\
\text { single-country analysis } \\
\text { - Source: Capitalia (2001- } \\
\text { 2003) } \\
\text { 4.2 Empirical strategy: } \\
\text { - Descriptive statistics } \\
\text { - Econometric analysis: } \\
\text { regressions (cross-section: } \\
\text { Probit, Maximum Likelihood) }\end{array}$ & $\begin{array}{l}\text { 5.1 Direction: } \\
\text { - self-selection } \\
5.2 \text { Econometric tools: } \\
\text { none }\end{array}$ & $\begin{array}{l}\text { 6.1 Common patterns } \\
\text { Innovation } \\
6.2 \text { Degree of } \\
\text { internationalisation: } \\
\text { none } \\
6.3 \text { Performance } \\
\text { premiums/discounts: } \\
\text { More investment in innovation is } \\
\text { associated with less offshoring. }\end{array}$ \\
\hline $\begin{array}{l}\text { Benfratello et al. } \\
\text { (2014) }\end{array}$ & $\begin{array}{l}\text { 2.1 Categories of } \\
\text { international involvement: } \\
\text { - export (status; intensity) } \\
\text { 2.2 Comparison strategy: } \\
\text { One variable for each category, } \\
\text { to compare international } \\
\text { enterprises with themselves } \\
\text { and with domestic players. }\end{array}$ & $\begin{array}{l}\text { 3.1 Economic: } \\
\text { - size (employees) } \\
\text { - productivity (labour } \\
\text { productivity) } \\
\text { 3.2 Human capital and } \\
\text { innovation: } \\
\text { - R\&D investment } \\
\text { 3.3 Financial: } \\
\text { none }\end{array}$ & $\begin{array}{l}\text { 4.1 Data: } \\
\text { - Type: manufacturing sector, } \\
\text { single-country analysis } \\
\text { - Source: Capitalia (1992-1994; } \\
\text { 1995-1997; 1998-2000; 2001- } \\
\text { 2003) } \\
\text { 4.2 Empirical strategy: } \\
\text { - Descriptive statistics } \\
\text { - Econometric analysis: } \\
\text { regressions (cross-section: } \\
\text { OLS, Tobit, Tobit IV, CQR, } \\
\text { CQIV) }\end{array}$ & $\begin{array}{l}\text { 5.1 Direction: } \\
\text { - self-selection } \\
\text { 5.2 Econometric tools: } \\
\text { - lagged variables }\end{array}$ & $\begin{array}{l}\text { 6.1 Common patterns } \\
\text { Innovation } \\
6.2 \text { Degree of } \\
\text { internationalisation: } \\
\text { Exporters are the majority } \\
\text { (77\%). } \\
6.3 \text { Performance } \\
\text { premiums/discounts: } \\
\text { Exporters are larger, more } \\
\text { productive and more innovative } \\
\text { than non-exporters. These } \\
\text { differentials grow along the } \\
\text { export intensity distribution. In } \\
\text { particular, firms characterised } \\
\text { by export intensity of about } 35 \% \\
\text { take the highest advantage from } \\
\text { investing in R\&D. }\end{array}$ \\
\hline Bonaccorsi (1992) & $\begin{array}{l}\text { 2.1 Categories of } \\
\text { international involvement: } \\
\text { - export (status; intensity) } \\
\text { 2.2 Comparison strategy: } \\
\text { One variable for each category, } \\
\text { to compare international } \\
\text { enterprises with themselves } \\
\text { and with domestic players. }\end{array}$ & $\begin{array}{l}\text { 3.1 Economic: } \\
\text { - size (employees) } \\
\text { 3.2 Human capital and } \\
\text { innovation: } \\
\text { none } \\
\text { 3.3 Financial: } \\
\text { none }\end{array}$ & $\begin{array}{l}\text { 4.1 Data: } \\
\text { - Type: manufacturing sector, } \\
\text { single-country analysis } \\
\text { - Source: Mediocredito } \\
\text { Centrale (1986-1988) } \\
\text { 4.2 Empirical strategy: } \\
\text { - Descriptive statistics }\end{array}$ & $\begin{array}{l}\text { 5.1 Direction: } \\
\text { - self-selection } \\
5.2 \text { Econometric tools: } \\
\text { none }\end{array}$ & $\begin{array}{l}\text { 6.1 Common patterns } \\
\text { District affiliation and SMEs } \\
6.2 \text { Degree of } \\
\text { internationalisation: } \\
\text { Exporters are the majority. } \\
6.3 \text { Performance } \\
\text { premiums/discounts: } \\
\text { Size is positively correlated with } \\
\text { firms' export probability, not } \\
\text { correlated with export intensity. }\end{array}$ \\
\hline
\end{tabular}




\begin{tabular}{|c|c|c|c|c|c|}
\hline $\begin{array}{l}\text { Bratti and Felice } \\
(2012)\end{array}$ & $\begin{array}{l}\text { 2.1 Categories of } \\
\text { international involvement: } \\
\text { - export (status) } \\
\text { 2.2 Comparison strategy: } \\
\text { One variable for each category, } \\
\text { to compare international } \\
\text { enterprises with themselves } \\
\text { and with domestic players. }\end{array}$ & $\begin{array}{l}\text { 3.1 Economic: } \\
\text { none } \\
\text { 3.2 Human capital and } \\
\text { innovation: } \\
\text { - dummy for product innovation } \\
\text { 3.3 Financial: } \\
\text { none }\end{array}$ & $\begin{array}{l}\text { 4.1 Data: } \\
\text { - Type: manufacturing sector, } \\
\text { single-country analysis } \\
\text { - Source: Capitalia (1998-2000; } \\
\text { 2001-2003) } \\
\text { 4.2 Empirical strategy: } \\
\text { - Descriptive statistics } \\
\text { - Econometric analysis: } \\
\text { regressions (cross-section: } \\
\text { OLS) }\end{array}$ & $\begin{array}{l}\text { 5.1 Direction: } \\
\text { - learning-by- } \\
\text { internationalisation } \\
5.2 \text { Econometric tools: } \\
\text { - lagged variables }\end{array}$ & $\begin{array}{l}\text { 6.1 Common patterns } \\
\text { Innovation } \\
6.2 \text { Degree of } \\
\text { internationalisation: } \\
\text { Exporters are the majority. } \\
6.3 \text { Performance } \\
\text { premiums/discounts: } \\
\text { Export has a positive impact on } \\
\text { innovation. }\end{array}$ \\
\hline $\begin{array}{l}\text { Bugamelli et al. } \\
(2000,2001)\end{array}$ & $\begin{array}{l}\text { 2.1 Categories of } \\
\text { international involvement: } \\
\text { - export (status) } \\
\text { - FDI (status) } \\
\text { - international partnerships } \\
\text { (status of commercial } \\
\text { partnership; status of } \\
\text { production partnership) } \\
\text { 2.2 Comparison strategy: } \\
\text { One variable for each category, } \\
\text { to compare international } \\
\text { enterprises with themselves } \\
\text { and with domestic players. }\end{array}$ & $\begin{array}{l}\text { 3.1 Economic: } \\
\text { - size (employees) } \\
\text { - age } \\
\text { 3.2 Human capital and } \\
\text { innovation: } \\
\text { none } \\
\text { 3.3 Financial: } \\
\text { none }\end{array}$ & $\begin{array}{l}\text { 4.1 Data: } \\
\text { - Type: manufacturing sector, } \\
\text { single-country analysis } \\
\text { - Source: Mediocredito } \\
\text { Centrale (1989-1991; 1992- } \\
\text { 1994; 1995-1997) } \\
\text { 4.2 Empirical strategy: } \\
\text { - Descriptive statistics } \\
\text { - Econometric analysis: } \\
\text { regressions (cross-section: } \\
\text { Probit) }\end{array}$ & $\begin{array}{l}\text { 5.1 Direction: } \\
\text { - self-selection } \\
\text { 5.2 Econometric tools: } \\
\text { none }\end{array}$ & $\begin{array}{l}\text { 6.1 Common patterns } \\
\text { Structural features of the Italian } \\
\text { economy } \\
\text { 6.2 Degree of } \\
\text { internationalisation: } \\
\text { Exporters are the majority. } \\
\text { Firms engaged in FDI or } \\
\text { international partnerships are } \\
\text { the minority. } \\
\text { 6.3 Performance } \\
\text { premiums/discounts: } \\
\text { Size is positively correlated with } \\
\text { all internationalisation } \\
\text { measures. Age is positively } \\
\text { correlated with export, } \\
\text { negatively correlated with } \\
\text { production partnerships, and not } \\
\text { correlated with FDI and } \\
\text { commercial partnerships. }\end{array}$ \\
\hline $\begin{array}{l}\text { Bugamelli and } \\
\text { Infante (2003) }\end{array}$ & $\begin{array}{l}\text { 2.1 Categories of } \\
\text { international involvement: } \\
\text { - export (status) } \\
\text { 2.2 Comparison strategy: } \\
\text { One variable for each category, } \\
\text { to compare international } \\
\text { enterprises with themselves } \\
\text { and with domestic players. }\end{array}$ & $\begin{array}{l}\text { 3.1 Economic: } \\
\text { - size (employees) } \\
\text { - productivity (labour } \\
\text { productivity) } \\
\text { - international experience } \\
\text { (dummy for past experience as } \\
\text { an exporter) } \\
\text { - group affiliation } \\
\text { - district affiliation } \\
\text { - wage } \\
\text { 3.2 Human capital and } \\
\text { innovation: } \\
\text { none } \\
\text { 3.3 Financial: } \\
\text { none }\end{array}$ & $\begin{array}{l}\text { 4.1 Data: } \\
\text { - Type: manufacturing sector, } \\
\text { single-country analysis } \\
\text { - Source: Centrale dei Bilanci } \\
\text { (1982-1999) } \\
\text { 4.2 Empirical strategy: } \\
\text { - Descriptive statistics } \\
\text { - Econometric analysis: } \\
\text { regressions (panel: Random } \\
\text { Effect Probit) }\end{array}$ & $\begin{array}{l}\text { 5.1 Direction: } \\
\text { - self-selection } \\
\text { 5.2 Econometric tools: } \\
\text { none }\end{array}$ & $\begin{array}{l}\text { 6.1 Common patterns } \\
\text { Financial market } \\
\text { 6.2 Degree of } \\
\text { internationalisation: } \\
\text { Exporters were the minority } \\
\text { (35\%) during the } 1980 \mathrm{~s}, \text { but } \\
\text { they became the majority }(60 \%) \\
\text { one decade later. } \\
6.3 \text { Performance } \\
\text { premiums/discounts: } \\
\text { Size, productivity, past } \\
\text { experience as an exporter and } \\
\text { location within a group/district } \\
\text { increase firms' probability to } \\
\text { export, while the average wage } \\
\text { has a negative impact. }\end{array}$ \\
\hline $\begin{array}{l}\text { Bugamelli and Gallo } \\
(2012)\end{array}$ & $\begin{array}{l}\text { 2.1 Categories of } \\
\text { international involvement: } \\
\text { - export (status of "big } \\
\text { exporters", i.e., firms exporting }\end{array}$ & $\begin{array}{l}\text { 3.1 Economic: } \\
\text { - size (employees, sales) } \\
\text { - productivity (labour } \\
\text { productivity) } \\
\end{array}$ & $\begin{array}{l}\text { 4.1 Data: } \\
\text { - Type: manufacturing sector, } \\
\text { single-country analysis } \\
\text { - Source: Invind (2007-2010) }\end{array}$ & $\begin{array}{l}\text { 5.1 Direction: } \\
\text { - self-selection } \\
\text { 5.2 Econometric tools: } \\
\text { none }\end{array}$ & $\begin{array}{l}\text { 6.1 Common patterns } \\
\text { Structural features of the Italian } \\
\text { economy } \\
6.2 \text { Degree of }\end{array}$ \\
\hline
\end{tabular}




\begin{tabular}{|c|c|c|c|c|c|}
\hline & $\begin{array}{l}\text { more than } 15 \text { mln Euro in } \\
\text { 2007) } \\
\text { 2.2 Comparison strategy: } \\
\text { One variable for each category, } \\
\text { to compare international } \\
\text { enterprises with themselves } \\
\text { and with domestic players. }\end{array}$ & $\begin{array}{l}\text { - value added } \\
\text { - international experience } \\
\text { (dummy for commercial or } \\
\text { technical collaboration with } \\
\text { foreign enterprises, number of } \\
\text { foreign affiliates) } \\
\text { - wage } \\
\text { - type of ownership \& control } \\
\text { (dummy for family ownership, } \\
\text { dummy for foreign ownership) } \\
\text { - investment in tangible assets } \\
\text { 3.2 Human capital and } \\
\text { innovation: } \\
\text { - share of white collar } \\
\text { employees } \\
\text { - share of graduates } \\
\text { - share of foreign employees } \\
\text { - share of permanent } \\
\text { employees } \\
\text { - R\&D investment } \\
\text { - dummy for investment in } \\
\text { intangible assets } \\
\text { 3.3 Financial: } \\
\text { none }\end{array}$ & $\begin{array}{l}\text { 4.2 Empirical strategy: } \\
\text { - Descriptive statistics } \\
\text { - Econometric analysis: } \\
\text { regressions (cross-section: } \\
\text { Probit) }\end{array}$ & & $\begin{array}{l}\text { internationalisation: } \\
\text { Big exporters are the minority } \\
\text { (11\%). } \\
6.3 \text { Performance } \\
\text { premiums/discounts: } \\
\text { Big exporters have larger size, } \\
\text { value added, productivity, R\&D } \\
\text { investment, investment in } \\
\text { intangible assets, international } \\
\text { experience; they pay higher } \\
\text { wages and exhibit a larger } \\
\text { share of white collar employees, } \\
\text { foreign employees, graduates } \\
\text { than the rest of the sample. On } \\
\text { the contrary, big exporters } \\
\text { display less investment in } \\
\text { tangible assets and lower } \\
\text { probability of family ownership. }\end{array}$ \\
\hline $\begin{array}{l}\text { Campanini and } \\
\text { Falzoni (2001) }\end{array}$ & $\begin{array}{l}\text { 2.1 Categories of } \\
\text { international involvement: } \\
\text { - export (status of "big } \\
\text { exporters". i.e., firms exporting } \\
\text { more than } 20 \% \text { of sales) } \\
2.2 \text { Comparison strategy: } \\
\text { One variable for each category, } \\
\text { to compare international } \\
\text { enterprises with themselves } \\
\text { and with domestic players. }\end{array}$ & $\begin{array}{l}\text { 3.1 Economic: } \\
\text { - size (employees, sales) } \\
\text { - international experience } \\
\text { (dummy for } \mathrm{n} \text {. of destinations; } \\
\text { dummy for type of distribution } \\
\text { channel) } \\
\text { 3.2 Human capital and } \\
\text { innovation: } \\
\text { - dummy for firm's certification } \\
\text { 3.3 Financial: } \\
\text { none }\end{array}$ & $\begin{array}{l}\text { 4.1 Data: } \\
\text { - Type: manufacturing sector, } \\
\text { single-country analysis } \\
\text { - Source: SDOE (1994) } \\
\text { 4.2 Empirical strategy: } \\
\text { - Descriptive statistics } \\
\text { - Econometric analysis: } \\
\text { regressions (cross-section: } \\
\text { Probit) }\end{array}$ & $\begin{array}{l}\text { 5.1 Direction: } \\
\text { - self-selection } \\
\text { 5.2 Econometric tools: } \\
\text { none }\end{array}$ & $\begin{array}{l}\text { 6.1 Common patterns } \\
\text { District affiliation and SMEs } \\
\text { 6.2 Degree of } \\
\text { internationalisation: } \\
\text { Big exporters are the minority. } \\
\text { 6.3 Performance } \\
\text { premiums/discounts: } \\
\text { Export is positively correlated } \\
\text { with international experience, } \\
\text { while it is not affected by size } \\
\text { and innovation. }\end{array}$ \\
\hline $\begin{array}{l}\text { Casaburi et al. } \\
\text { (2007) }\end{array}$ & $\begin{array}{l}\text { 2.1 Categories of } \\
\text { international involvement: } \\
\text { - export (status) } \\
\text { - FDI (status) } \\
\text { - offshoring (status; status of } \\
\text { offshoring firms in EU; status of } \\
\text { offshoring firms of inputs; } \\
\text { status of offshoring firms of } \\
\text { final goods) } \\
2.2 \text { Comparison strategy: } \\
\text { One variable for each category, } \\
\text { to compare international } \\
\text { enterprises with themselves } \\
\text { and with domestic players. }\end{array}$ & $\begin{array}{l}\text { 3.1 Economic: } \\
\text { - size (employees, sales) } \\
\text { - productivity (labour } \\
\text { productivity, TFP) } \\
\text { - capital intensity } \\
\text { - wage } \\
\text { 3.2 Human capital and } \\
\text { innovation: } \\
\text { none } \\
\text { 3.3 Financial: } \\
\text { none }\end{array}$ & $\begin{array}{l}\text { 4.1 Data: } \\
\text { - Type: manufacturing sector, } \\
\text { single-country analysis } \\
\text { - Source: Capitalia (1998-2000; } \\
\text { 2001-2003) } \\
\text { 4.2 Empirical strategy: } \\
\text { - Descriptive statistics } \\
\text { - Econometric analysis: } \\
\text { regressions (cross-section: } \\
\text { OLS) }\end{array}$ & $\begin{array}{l}\text { 5.1 Direction: } \\
\text { - self-selection } \\
\text { - learning-by- } \\
\text { internationalisation } \\
\text { 5.2 Econometric tools: } \\
\text { - TFP dynamics } \\
\text { (support to self-selection) }\end{array}$ & $\begin{array}{l}\text { 6.1 Common patterns } \\
\text { Not only export } \\
\text { 6.2 Degree of } \\
\text { internationalisation: } \\
\text { Exporters are the majority } \\
\text { (75\%). Firms engaged in FDI } \\
\text { (8\%) and offshoring (7\%) are } \\
\text { the minority. Export is } \\
\text { concentrated in the hands of top } \\
\text { 1\%, top } 5 \% \text { and top } 10 \% \text { of } \\
\text { exporters. } \\
\text { 6.3 Performance } \\
\text { premiums/discounts: } \\
\text { Firms engaged in any }\end{array}$ \\
\hline
\end{tabular}




\begin{tabular}{|c|c|c|c|c|c|}
\hline & & & & & $\begin{array}{l}\text { international activity are better } \\
\text { performing than domestic } \\
\text { players. } \\
\text { As far as productivity is } \\
\text { concerned, offshoring firms of } \\
\text { final goods are more productive } \\
\text { than offshoring firms of inputs } \\
\text { and exporters. }\end{array}$ \\
\hline Castellani (2002) & $\begin{array}{l}\text { 2.1 Categories of } \\
\text { international involvement: } \\
\text { - export (status; intensity); } \\
\text { 2.2 Comparison strategy: } \\
\text { One variable for each category, } \\
\text { to compare international } \\
\text { enterprises with themselves } \\
\text { and with domestic players. }\end{array}$ & $\begin{array}{l}\text { 3.1 Economic: } \\
\text { - productivity (labour } \\
\text { productivity; growth rate of } \\
\text { labour productivity) } \\
\text { 3.2 Human capital and } \\
\text { innovation: } \\
\text { none } \\
\text { 3.3 Financial: } \\
\text { none }\end{array}$ & $\begin{array}{l}\text { 4.1 Data: } \\
\text { - Type: manufacturing sector, } \\
\text { single-country analysis } \\
\text { - Source: Mediocredito } \\
\text { Centrale (1989-1991; 1992- } \\
\text { 1994) } \\
\text { 4.2 Empirical strategy: } \\
\text { - Econometric analysis: } \\
\text { regressions (cross-section: } \\
\text { Probit, Tobit, QL-PW, OLS) }\end{array}$ & $\begin{array}{l}\text { 5.1 Direction: } \\
\text { - self-selection } \\
\text { - learning-by- } \\
\text { internationalisation } \\
5.2 \text { Econometric tools: } \\
\text { - lagged variables }\end{array}$ & $\begin{array}{l}\text { 6.1 Common patterns } \\
\text { Causal links between export } \\
\text { and productivity } \\
6.2 \text { Degree of } \\
\text { internationalisation: } \\
\text { none } \\
6.3 \text { Performance } \\
\text { premiums/discounts: } \\
\text { Productivity does not affect } \\
\text { firms' export status, but it } \\
\text { positively affects export } \\
\text { intensity. } \\
\text { Export intensity has a positive } \\
\text { impact on productivity, while } \\
\text { export status has none. }\end{array}$ \\
\hline Castellani (2007) & $\begin{array}{l}\text { 2.1 Categories of } \\
\text { international involvement: } \\
\text { - export (status) } \\
\text { - offshoring (status) } \\
2.2 \text { Comparison strategy: } \\
\text { One variable for each category, } \\
\text { to compare international } \\
\text { enterprises with themselves } \\
\text { and with domestic players. }\end{array}$ & $\begin{array}{l}\text { 3.1 Economic: } \\
\text { - size (sales per employee) } \\
\text { 3.2 Human capital and } \\
\text { innovation: } \\
\text { - share of white collar } \\
\text { employees } \\
\text { - share of blue collar } \\
\text { employees } \\
\text { - share of graduates } \\
\text { - share of R\&D personnel } \\
\text { - R\&D investment } \\
\text { - ICT investment } \\
\text { - dummy for product/process } \\
\text { innovation } \\
\text { 3.3 Financial: } \\
\text { none }\end{array}$ & $\begin{array}{l}\text { 4.1 Data: } \\
\text { - Type: manufacturing sector, } \\
\text { single-country analysis } \\
\text { - Source: Capitalia (2001- } \\
\text { 2003) } \\
\text { 4.2 Empirical strategy: } \\
\text { - Descriptive statistics } \\
\text { - Econometric analysis: } \\
\text { regressions (cross-section: } \\
\text { OLS, Probit, Tobit) }\end{array}$ & $\begin{array}{l}\text { 5.1 Direction: } \\
\text { - self-selection } \\
5.2 \text { Econometric tools: } \\
\text { none }\end{array}$ & $\begin{array}{l}\text { 6.1 Common patterns } \\
\text { Structural features of the Italian } \\
\text { economy } \\
6.2 \text { Degree of } \\
\text { internationalisation: } \\
\text { none } \\
6.3 \text { Performance } \\
\text { premiums/discounts: } \\
\text { Exporters and offshoring firms } \\
\text { are larger, more productive and } \\
\text { more innovative and they } \\
\text { employ better human capital } \\
\text { than domestic players. }\end{array}$ \\
\hline $\begin{array}{l}\text { Castellani and Zanfei } \\
(2007)\end{array}$ & $\begin{array}{l}\text { 2.1 Categories of } \\
\text { international involvement: } \\
\text { - export (status) } \\
\text { - FDI (status of production FDI, } \\
\text { status of commercial FDI) } \\
2.2 \text { Comparison strategy: } \\
\text { One variable for each category, } \\
\text { to compare international } \\
\text { enterprises with themselves }\end{array}$ & $\begin{array}{l}\text { 3.1 Economic: } \\
\text { - productivity (labour } \\
\text { productivity; TFP) } \\
\text { 3.2 Human capital and } \\
\text { innovation: } \\
\text { - dummy for patent application } \\
\text { - dummy for product/process } \\
\text { innovation } \\
\text { - dummy for technical } \\
\end{array}$ & $\begin{array}{l}\text { 4.1 Data: } \\
\text { - Type: manufacturing sector, } \\
\text { single-country analysis } \\
\text { - Source: CIS (1994-1996) + } \\
\text { ELIOS (1996) } \\
\text { 4.2 Empirical strategy: } \\
\text { - Descriptive statistics } \\
\text { - Econometric analysis: } \\
\text { regressions (cross-section: }\end{array}$ & $\begin{array}{l}\text { 5.1 Direction: } \\
\text { - learning-by- } \\
\text { internationalisation } \\
5.2 \text { Econometric tools: } \\
\text { none }\end{array}$ & $\begin{array}{l}\text { 6.1 Common patterns } \\
\text { Innovation } \\
6.2 \text { Degree of } \\
\text { internationalisation: } \\
\text { Firms engaged in international } \\
\text { activities are the majority of } \\
\text { Italian enterprises. } \\
6.3 \text { Performance } \\
\text { premiums/discounts: }\end{array}$ \\
\hline
\end{tabular}




\begin{tabular}{|c|c|c|c|c|c|}
\hline & and with domestic players. & $\begin{array}{l}\text { collaboration with } \\
\text { competitors/clients/suppliers } \\
\text { 3.3 Financial: } \\
\text { none }\end{array}$ & OLS) & & $\begin{array}{l}\text { Firms engaged in production } \\
\text { FDI are more productive and } \\
\text { innovative than firms engaged } \\
\text { in commercial FDI which, in } \\
\text { turn, are more productive than } \\
\text { exporters. }\end{array}$ \\
\hline $\begin{array}{l}\text { Castellani and } \\
\text { Giovannetti (2008) }\end{array}$ & $\begin{array}{l}\text { 2.1 Categories of } \\
\text { international involvement: } \\
\text { - export (status) } \\
\text { - FDI (status) } \\
\text { 2.2 Comparison strategy: } \\
\text { One variable for each category, } \\
\text { to compare international } \\
\text { enterprises with themselves } \\
\text { and with domestic players. }\end{array}$ & $\begin{array}{l}\text { 3.1 Economic: } \\
\text { - productivity (labour } \\
\text { productivity; TFP) } \\
\text { 3.2 Human capital and } \\
\text { innovation: } \\
\text { none } \\
\text { 3.3 Financial: } \\
\text { none }\end{array}$ & $\begin{array}{l}\text { 4.1 Data: } \\
\text { - Type: manufacturing sector, } \\
\text { single-country analysis } \\
\text { - Source: Capitalia (1998-2000; } \\
\text { 2001-2003) + Ice Reprint } \\
\text { (2001) } \\
\text { 4.2 Empirical strategy: } \\
\text { - Descriptive statistics } \\
\text { - Econometric analysis: } \\
\text { regressions (panel: Pooled } \\
\text { OLS, fixed effects) }\end{array}$ & $\begin{array}{l}\text { 5.1 Direction: } \\
\text { - learning-by- } \\
\text { internationalisation } \\
5.2 \text { Econometric tools: } \\
\text { none }\end{array}$ & $\begin{array}{l}\text { 6.1 Common patterns } \\
\text { Not only export } \\
\text { 6.2 Degree of } \\
\text { internationalisation: } \\
\text { Exporters (not engaged in FDI) } \\
\text { are the majority (65\%). Firms } \\
\text { engaged in FDI are the minority } \\
(10 \%) \text {. } \\
6.3 \text { Performance } \\
\text { premiums/discounts: } \\
\text { Firms engaged in FDI are more } \\
\text { productive than exporters } \\
\text { which, in turn, are more } \\
\text { productive than domestic } \\
\text { players. }\end{array}$ \\
\hline $\begin{array}{l}\text { Castellani et al. } \\
(2010)\end{array}$ & $\begin{array}{l}\text { 2.1 Categories of } \\
\text { international involvement: } \\
\text { - export (status; n. of exported } \\
\text { goods; n. of destinations) } \\
\text { - import (status; n. of imported } \\
\text { goods; n. of origins) } \\
\text { - two-way trading (status) } \\
\text { 2.2 Comparison strategy: } \\
\text { One variable for each category, } \\
\text { to compare international } \\
\text { enterprises with themselves } \\
\text { and with domestic players. }\end{array}$ & $\begin{array}{l}\text { 3.1 Economic: } \\
\text { - productivity (labour } \\
\text { productivity; TFP) } \\
\text { - size (employees, sales) } \\
\text { - capital intensity } \\
\text { 3.2 Human capital and } \\
\text { innovation: } \\
\text { none } \\
\text { 3.3 Financial: } \\
\text { none }\end{array}$ & $\begin{array}{l}\text { 4.1 Data: } \\
\text { - Type: manufacturing sector, } \\
\text { single-country analysis } \\
\text { - Source: MICRO1 (1989- } \\
\text { 1997) + COE (1993-1997) } \\
\text { 4.2 Empirical strategy: } \\
\text { - Descriptive statistics } \\
\text { - Econometric analysis: } \\
\text { regressions (panel: Pooled } \\
\text { OLS, fixed effects) }\end{array}$ & $\begin{array}{l}\text { 5.1 Direction: } \\
\text { - self-selection } \\
\text { 5.2 Econometric tools: } \\
\text { - explicit test for causality } \\
\text { (Bernard and Jensen } \\
\text { methodology) }\end{array}$ & $\begin{array}{l}\text { 6.1 Common patterns } \\
\text { The import-export nexus } \\
6.2 \text { Degree of } \\
\text { internationalisation: } \\
\text { Firms trading many goods in } \\
\text { many markets are the minority } \\
\text { of traders, but they are } \\
\text { responsible for a good deal of } \\
\text { Italian trade. } \\
6.3 \text { Performance } \\
\text { premiums/discounts: } \\
\text { Two-way traders perform better } \\
\text { than importers which, in turn, } \\
\text { perform better than exporters, } \\
\text { according to all performance } \\
\text { indicators. }\end{array}$ \\
\hline $\begin{array}{l}\text { Castellani and } \\
\text { Giovannetti (2010) }\end{array}$ & $\begin{array}{l}\text { 2.1 Categories of } \\
\text { international involvement: } \\
\text { - export (status) } \\
\text { - FDI (status) } \\
\text { 2.2 Comparison strategy: } \\
\text { One variable for each category, } \\
\text { to compare international } \\
\text { enterprises with themselves } \\
\text { and with domestic players. }\end{array}$ & $\begin{array}{l}\text { 3.1 Economic: } \\
\text { - productivity (TFP) } \\
\text { 3.2 Human capital and } \\
\text { innovation: } \\
\text { none } \\
\text { 3.3 Financial: } \\
\text { none }\end{array}$ & $\begin{array}{l}\text { 4.1 Data: } \\
\text { - Type: manufacturing sector, } \\
\text { single-country analysis } \\
\text { - Source: Capitalia (1998-2000; } \\
\text { 2001-2003) + Ice Reprint } \\
\text { (2001) } \\
\text { 4.2 Empirical strategy: } \\
\text { - Descriptive statistics } \\
\text { - Econometric analysis: } \\
\text { regressions (cross-section: } \\
\text { OLS) }\end{array}$ & $\begin{array}{l}\text { 5.1 Direction: } \\
\text { - learning-by- } \\
\text { internationalisation } \\
5.2 \text { Econometric tools: } \\
\text { none }\end{array}$ & $\begin{array}{l}\text { 6.1 Common patterns } \\
\text { Not only export } \\
\text { 6.2 Degree of } \\
\text { internationalisation: } \\
\text { Exporters are the majority } \\
\text { (75\%). Firms engaged in FDI } \\
\text { are the minority (9\%). } \\
6.3 \text { Performance } \\
\text { premiums/discounts: } \\
\text { Firms engaged in FDI are more } \\
\text { productive than exporters }\end{array}$ \\
\hline
\end{tabular}




\begin{tabular}{|c|c|c|c|c|c|}
\hline & & & & & $\begin{array}{l}\text { which, in turn, are more } \\
\text { productive than domestic } \\
\text { players. }\end{array}$ \\
\hline $\begin{array}{l}\text { Conti et al. } \\
(2010 a, b)\end{array}$ & $\begin{array}{l}\text { 2.1 Categories of } \\
\text { international involvement: } \\
\text { - export (intensity; status; } \\
\text { status of exporters to EU; } \\
\text { status of exporters to EU15; } \\
\text { status of exporters to extra EU; } \\
\text { status of exporters to extra EU } \\
\text { industrial countries) } \\
\text { 2.2 Comparison strategy: } \\
\text { One variable for each category, } \\
\text { to compare international } \\
\text { enterprises with themselves } \\
\text { and with domestic players. }\end{array}$ & $\begin{array}{l}\text { 3.1 Economic: } \\
\text { - productivity (labour } \\
\text { productivity) } \\
\text { - age } \\
\text { - group affiliation } \\
\text { - type of customers (dummy for } \\
\text { selling to large companies; } \\
\text { dummy for selling to SMEs) } \\
\text { - labour flexibility (dummy for } \\
\text { employing any form of labour } \\
\text { considered as flexible by the } \\
\text { Italian law) } \\
\text { 3.2 Human capital and } \\
\text { innovation: } \\
\text { - share of graduates } \\
\text { - dummy for service/process } \\
\text { innovation } \\
\text { 3.3 Financial: } \\
\text { none }\end{array}$ & $\begin{array}{l}\text { 4.1 Data: } \\
\text { - Type: service sector, single- } \\
\text { country analysis } \\
\text { - Source: Capitalia (2001- } \\
\text { 2003) } \\
\text { 4.2 Empirical strategy: } \\
\text { - Descriptive statistics } \\
\text { - Econometric analysis: } \\
\text { regressions (cross-section: } \\
\text { Probit, Truncated regressions) }\end{array}$ & $\begin{array}{l}\text { 5.1 Direction: } \\
\text { - self-selection } \\
5.2 \text { Econometric tools: } \\
\text { none }\end{array}$ & $\begin{array}{l}\text { 6.1 Common patterns } \\
\text { Service } \\
6.2 \text { Degree of } \\
\text { internationalisation: } \\
\text { Exporters, in the service } \\
\text { industry, are the minority (24\%). } \\
6.3 \text { Performance } \\
\text { premiums/discounts: } \\
\text { Selling to large companies, } \\
\text { belonging to industrial groups } \\
\text { and firms' age are positively } \\
\text { correlated with the export } \\
\text { status. Human capital and } \\
\text { productivity } \\
\text { are positively correlated with the } \\
\text { status of exporters to more } \\
\text { distant countries. } \\
\text { More flexible labour and a lower } \\
\text { share of national sales are } \\
\text { positively correlated with the } \\
\text { export intensity. Innovation is } \\
\text { positively correlated with the } \\
\text { export intensity to more distant } \\
\text { countries. }\end{array}$ \\
\hline Conti et al. (2013) & $\begin{array}{l}\text { 2.1 Categories of } \\
\text { international involvement: } \\
\text { - import (status of importers } \\
\text { from high-income countries; } \\
\text { status of importers from low- } \\
\text { income countries; intensity of } \\
\text { import from high-income } \\
\text { countries; intensity of import } \\
\text { from low-income countries) } \\
\text { - export (intensity) } \\
\text { 2.2 Comparison strategy: } \\
\text { One variable for each category, } \\
\text { to compare international } \\
\text { enterprises with themselves } \\
\text { and with domestic players. }\end{array}$ & $\begin{array}{l}\text { 3.1 Economic: } \\
\text { - productivity (labour } \\
\text { productivity; TFP) } \\
\text { 3.2 Human capital and } \\
\text { innovation: } \\
\text { none } \\
\text { 3.3 Financial: } \\
\text { none }\end{array}$ & $\begin{array}{l}\text { 4.1 Data: } \\
\text { - Type: manufacturing sector, } \\
\text { single-country analysis } \\
\text { - Source: ASIA + COE (2000- } \\
\text { 2004) } \\
\text { 4.2 Empirical strategy: } \\
\text { - Econometric analysis: } \\
\text { regressions (panel: Pooled } \\
\text { OLS, fixed effects, GMM-SYS, } \\
\text { GMM-DIFF, PSM) }\end{array}$ & $\begin{array}{l}\text { 5.1 Direction: } \\
\text { - learning-by- } \\
\text { internationalisation } \\
\text { 5.2 Econometric tools: } \\
\text { - explicit test for causality } \\
\text { (PSM with internationalisation } \\
\text { in the treatment) }\end{array}$ & $\begin{array}{l}\text { 6.1 Common patterns } \\
\text { The import-export nexus } \\
6.2 \text { Degree of } \\
\text { internationalisation: } \\
\text { Importers of intermediates are } \\
\text { the minority ( } 31 \% \text { import from } \\
\text { high-income countries; } 25 \% \\
\text { from low-income countries). } \\
6.3 \text { Performance } \\
\text { premiums/discounts: } \\
\text { Once export activities are } \\
\text { accounted for, there is no } \\
\text { significant effect of import on } \\
\text { productivity, while export turns } \\
\text { out to positively affect firms' } \\
\text { performance. }\end{array}$ \\
\hline
\end{tabular}




\begin{tabular}{|c|c|c|c|c|c|}
\hline Crinò (2010) & $\begin{array}{l}\text { 2.1 Categories of } \\
\text { international involvement: } \\
\text { - offshoring (status of } \\
\text { offshoring firms of services; } \\
\text { status of offshoring firms of } \\
\text { business services) } \\
\text { 2.2 Comparison strategy: } \\
\text { One variable for each category, } \\
\text { to compare international } \\
\text { enterprises with themselves } \\
\text { and with domestic players. }\end{array}$ & $\begin{array}{l}\text { 3.1 Economic: } \\
\text { - size (employees) } \\
\text { 3.2 Human capital and } \\
\text { innovation: } \\
\text { - share of graduates } \\
\text { 3.3 Financial: } \\
\text { none }\end{array}$ & $\begin{array}{l}\text { 4.1 Data: } \\
\text { - Type: manufacturing sector, } \\
\text { single-country analysis } \\
\text { - Source: Capitalia (2001- } \\
\text { 2003) } \\
\text { 4.2 Empirical strategy: } \\
\text { - Descriptive statistics } \\
\text { - Econometric analysis: } \\
\text { regressions (cross-section: } \\
\text { PSM) }\end{array}$ & $\begin{array}{l}\text { 5.1 Direction: } \\
\text { - learning-by- } \\
\text { internationalisation } \\
\text { 5.2 Econometric tools: } \\
\text { - explicit test for causality } \\
\text { (PSM with internationalisation } \\
\text { in the treatment) }\end{array}$ & $\begin{array}{l}\text { 6.1 Common patterns } \\
\text { Labour market } \\
6.2 \text { Degree of } \\
\text { internationalisation: } \\
\text { none } \\
6.3 \text { Performance } \\
\text { premiums/discounts: } \\
\text { Service offshoring has no effect } \\
\text { on the level of employment but } \\
\text { changes its composition in } \\
\text { favour of high skilled workers. } \\
\end{array}$ \\
\hline $\begin{array}{l}\text { Crinò and Epifani } \\
\text { (2012) }\end{array}$ & $\begin{array}{l}\text { 2.1 Categories of } \\
\text { international involvement: } \\
\text { - export (intensity) } \\
2.2 \text { Comparison strategy: } \\
\text { One variable for each category, } \\
\text { to compare international } \\
\text { enterprises with themselves } \\
\text { and with domestic players. }\end{array}$ & $\begin{array}{l}\text { 3.1 Economic: } \\
\text { - productivity (TFP) } \\
\text { 3.2 Human capital and } \\
\text { innovation: } \\
\text { none } \\
\text { 3.3 Financial: } \\
\text { none }\end{array}$ & $\begin{array}{l}\text { 4.1 Data: } \\
\text { - Type: manufacturing sector, } \\
\text { single-country analysis } \\
\text { - Source: Capitalia (2001- } \\
\text { 2003) } \\
\text { 4.2 Empirical strategy: } \\
\text { - Econometric analysis: } \\
\text { regressions (cross-section: } \\
\text { Truncated regression) }\end{array}$ & $\begin{array}{l}\text { 5.1 Direction: } \\
\text { - self-selection } \\
\text { 5.2 Econometric tools: } \\
\text { none }\end{array}$ & $\begin{array}{l}\text { 6.1 Common patterns } \\
\text { The object of trade } \\
\text { 6.2 Degree of } \\
\text { internationalisation: } \\
\text { Exporters are the majority } \\
\text { (75\%). } \\
\text { 6.3 Performance } \\
\text { premiums/discounts: } \\
\text { Productivity is negatively } \\
\text { correlated with firms' export } \\
\text { intensity to low-income } \\
\text { destinations, and not correlated } \\
\text { with export intensity to high- } \\
\text { income destinations. }\end{array}$ \\
\hline D'Angelo (2012) & $\begin{array}{l}\text { 2.1 Categories of } \\
\text { international involvement: } \\
\text { - export (intensity) } \\
2.2 \text { Comparison strategy: } \\
\text { One variable for each category, } \\
\text { to compare international } \\
\text { enterprises with themselves } \\
\text { and with domestic players. }\end{array}$ & $\begin{array}{l}\text { 3.1 Economic: } \\
\text { - size (employees) } \\
\text { - age } \\
\text { 3.2 Human capital and } \\
\text { innovation: } \\
\text { - internal R\&D investment over } \\
\text { sales } \\
\text { - share of R\&D personnel } \\
\text { - external R\&D investment over } \\
\text { sales } \\
\text { - external R\&D (from } \\
\text { collaboration with universities) } \\
\text { over sales } \\
\text { - external R\&D (from } \\
\text { collaboration with other } \\
\text { companies) over sales } \\
\text { - external R\&D (from } \\
\text { collaboration with other } \\
\text { organizations) over sales } \\
\text { - dummy for product innovation } \\
\text { - dummy for process } \\
\text { innovation } \\
\text { - turnover from innovations } \\
\text { 3.3 Financial: }\end{array}$ & $\begin{array}{l}\text { 4.1 Data: } \\
\text { - Type: manufacturing sector, } \\
\text { single-country analysis } \\
\text { - Source: Capitalia (2001- } \\
\text { 2003) } \\
\text { 4.2 Empirical strategy: } \\
\text { - Descriptive statistics } \\
\text { - Econometric analysis: } \\
\text { regressions (cross-section: } \\
\text { Tobit) }\end{array}$ & $\begin{array}{l}\text { 5.1 Direction: } \\
\text { - self-selection } \\
\text { 5.2 Econometric tools: } \\
\text { - lagged variables }\end{array}$ & $\begin{array}{l}\text { 6.1 Common patterns } \\
\text { Innovation } \\
6.2 \text { Degree of } \\
\text { internationalisation: } \\
\text { Exporters are the majority } \\
\text { (84\%) compared with the entire } \\
\text { population of high tech SMEs. } \\
\text { The average export intensity is } \\
45 \% \text {. } \\
6.3 \text { Performance } \\
\text { premiums/discounts: } \\
\text { Product innovations, share of } \\
\text { R\&D employees, collaborations } \\
\text { with universities and turnover } \\
\text { from innovative activities are } \\
\text { positively correlated with high } \\
\text { tech SMEs' export intensity. }\end{array}$ \\
\hline
\end{tabular}




\begin{tabular}{|c|c|c|c|c|c|}
\hline & & none & & & \\
\hline $\begin{array}{l}\text { De Angelis et al. } \\
\text { (2011) }\end{array}$ & $\begin{array}{l}\text { 2.1 Categories of } \\
\text { international involvement: } \\
\text { - export (status) } \\
2.2 \text { Comparison strategy: } \\
\text { One variable for each category, } \\
\text { to compare international } \\
\text { enterprises with themselves } \\
\text { and with domestic players. }\end{array}$ & $\begin{array}{l}\text { 3.1 Economic: } \\
\text { - productivity (labour } \\
\text { productivity) } \\
\text { - size (sales per employee) } \\
\text { 3.2 Human capital and } \\
\text { innovation: } \\
\text { none } \\
\text { 3.3 Financial: } \\
\text { none }\end{array}$ & $\begin{array}{l}\text { 4.1 Data: } \\
\text { - Type: manufacturing sector, } \\
\text { single-country analysis } \\
\text { - Source: Prodcom + COE } \\
\text { (2006) } \\
\text { 4.2 Empirical strategy: } \\
\text { - Descriptive statistics }\end{array}$ & $\begin{array}{l}\text { 5.1 Direction: } \\
\text { - learning-by- } \\
\text { internationalisation } \\
5.2 \text { Econometric tools: } \\
\text { none }\end{array}$ & $\begin{array}{l}\text { 6.1 Common patterns } \\
\text { The object of trade } \\
\text { 6.2 Degree of } \\
\text { internationalisation: } \\
\text { Exporters are the majority } \\
\text { (60\%). Among exporters, multi- } \\
\text { product firms are the majority } \\
\text { (50\% or } 90 \% \text { depending on } \\
\text { whether multi-product firms are } \\
\text { defined according to the number } \\
\text { of produced goods or the } \\
\text { number of exported goods). } \\
\text { Multi-product exporters account } \\
\text { for the largest share (99\%) of } \\
\text { Italian total export. } \\
\text { 6.3 Performance } \\
\text { premiums/discounts: } \\
\text { Exporters are larger and more } \\
\text { productive than domestic firms. } \\
\text { Among exporters, multi-product } \\
\text { firms are larger and more } \\
\text { productive than mono-product } \\
\text { firms. }\end{array}$ \\
\hline $\begin{array}{l}\text { De Nardis and } \\
\text { Pappalardo (2009) }\end{array}$ & $\begin{array}{l}\text { 2.1 Categories of } \\
\text { international involvement: } \\
\text { - export (intensity) } \\
2.2 \text { Comparison strategy: } \\
\text { One variable for each category, } \\
\text { to compare international } \\
\text { enterprises with themselves } \\
\text { and with domestic players. }\end{array}$ & $\begin{array}{l}\text { 3.1 Economic: } \\
\text { - productivity (labour } \\
\text { productivity) } \\
\text { - size (employees) } \\
\text { 3.2 Human capital and } \\
\text { innovation: } \\
\text { none } \\
\text { 3.3 Financial: } \\
\text { none }\end{array}$ & $\begin{array}{l}\text { 4.1 Data: } \\
\text { - Type: manufacturing sector, } \\
\text { single-country analysis } \\
\text { - Source: Prodcom + ISAE } \\
\text { (2000-2005) } \\
\text { 4.2 Empirical strategy: } \\
\text { - Econometric analysis: } \\
\text { regressions (panel: Pooled } \\
\text { Tobit, Tobit random effects, } \\
\text { Correlated Tobit random } \\
\text { effects, Pooled Tobit IV, Tobit } \\
\text { random effects IV) }\end{array}$ & $\begin{array}{l}\text { 5.1 Direction: } \\
\text {-self-selection } \\
\text { - learning-by- } \\
\text { internationalisation } \\
\text { 5.2 Econometric tools: } \\
\text { - lagged variables } \\
\text { (support to both hypothesis) }\end{array}$ & $\begin{array}{l}\text { 6.1 Common patterns } \\
\text { The object of trade } \\
\text { 6.2 Degree of } \\
\text { internationalisation: } \\
\text { none } \\
6.3 \text { Performance } \\
\text { premiums/discounts: } \\
\text { Exporters are larger and more } \\
\text { productive than domestic firms. } \\
\text { This is the joint effect of self- } \\
\text { selection and product-switching. }\end{array}$ \\
\hline $\begin{array}{l}\text { Federico and Tosti } \\
\text { (2012) }\end{array}$ & $\begin{array}{l}\text { 2.1 Categories of } \\
\text { international involvement: } \\
\text { - export (status of exporters of } \\
\text { services; intensity) } \\
\text { - import (status of importers of } \\
\text { services; intensity) } \\
\text { 2.2 Comparison strategy: } \\
\text { One variable for each category, } \\
\text { to compare international } \\
\text { enterprises with themselves } \\
\text { and with domestic players. }\end{array}$ & $\begin{array}{l}\text { 3.1 Economic: } \\
\text { - productivity (labour } \\
\text { productivity) } \\
\text { - size (employees) } \\
\text { 3.2 Human capital and } \\
\text { innovation: } \\
\text { none } \\
\text { 3.3 Financial: } \\
\text { none }\end{array}$ & $\begin{array}{l}\text { 4.1 Data: } \\
\text { - Type: manufacturing sector, } \\
\text { single-country analysis } \\
\text { - Source: Services (2008-2009) } \\
\text { 4.2 Empirical strategy: } \\
\text { - Descriptive statistics } \\
\text { - Econometric analysis: } \\
\text { regressions (cross-section: } \\
\text { OLS) }\end{array}$ & $\begin{array}{l}\text { 5.1 Direction: } \\
\text { - self-selection } \\
\text { 5.2 Econometric tools: } \\
\text { none }\end{array}$ & $\begin{array}{l}\text { 6.1 Common patterns } \\
\text { Service } \\
\text { 6.2 Degree of } \\
\text { internationalisation: } \\
\text { Firms engaged in trade in } \\
\text { services are the majority ( } 60 \%) \text {. } \\
\text { Those that import and export } \\
\text { account for } 31 \% \text { of the total, } \\
\text { those that only import account } \\
\text { for } 25 \% \text { and those that only } \\
\text { export account for } 3 \% \text {. } \\
\text { 6.3 Performance } \\
\text { premiums/discounts: }\end{array}$ \\
\hline
\end{tabular}




\begin{tabular}{|c|c|c|c|c|c|}
\hline & & & & & $\begin{array}{l}\text { By and large there exists a } \\
\text { positive correlation between } \\
\text { export, size and productivity. }\end{array}$ \\
\hline $\begin{array}{l}\text { Ferragina and } \\
\text { Quintieri (2001) }\end{array}$ & $\begin{array}{l}\text { 2.1 Categories of } \\
\text { international involvement: } \\
\text { - export (status; intensity) } \\
\text { 2.2 Comparison strategy: } \\
\text { One variable for each category, } \\
\text { to compare international } \\
\text { enterprises with themselves } \\
\text { and with domestic players. }\end{array}$ & $\begin{array}{l}\text { 3.1 Economic: } \\
\text { - productivity (labour } \\
\text { productivity, TFP) } \\
\text { - size (employees, sales) } \\
\text { 3.2 Human capital and } \\
\text { innovation: } \\
\text { - share of white collar } \\
\text { employees } \\
\text { - share of graduates } \\
\text { - R\&D investment per } \\
\text { employee } \\
\text { - IT investment per employee } \\
\text { - share of investment in } \\
\text { innovative plants } \\
\text { 3.3 Financial: } \\
\text { none } \\
\end{array}$ & $\begin{array}{l}\text { 4.1 Data: } \\
\text { - Type: manufacturing sector, } \\
\text { single-country analysis } \\
\text { - Source: Mediocredito } \\
\text { Centrale (1995-1997); } \\
\text { Federmeccanica (1995) } \\
\text { 4.2 Empirical strategy: } \\
\text { - Descriptive statistics } \\
\text { - Econometric analysis: } \\
\text { regressions (cross-section: } \\
\text { OLS) }\end{array}$ & $\begin{array}{l}\text { 5.1 Direction: } \\
\text { - self-selection } \\
\text { - learning-by- } \\
\text { internationalisation } \\
\text { 5.2 Econometric tools: } \\
\text { - explicit test for causality } \\
\text { (Bernard and Jensen } \\
\text { methodology; support to self- } \\
\text { selection) }\end{array}$ & $\begin{array}{l}\text { 6.1 Common patterns } \\
\text { Causal links between export } \\
\text { and productivity } \\
\text { 6.2 Degree of } \\
\text { internationalisation: } \\
\text { Exporters are the majority ( } 75 \% \\
\text { according to Mediocredito } \\
\text { Centrale data, } 65 \% \text { according to } \\
\text { Federmeccanica data). } \\
6.3 \text { Performance } \\
\text { premiums/discounts: } \\
\text { By and large there exists a } \\
\text { positive correlation between } \\
\text { export and all performance } \\
\text { indicators. }\end{array}$ \\
\hline Forlani (2011) & $\begin{array}{l}\text { 2.1 Categories of } \\
\text { international involvement: } \\
\text { - export (status; n. of } \\
\text { destinations) } \\
\text { 2.2 Comparison strategy: } \\
\text { One variable for each category, } \\
\text { to compare international } \\
\text { enterprises with themselves } \\
\text { and with domestic players. }\end{array}$ & $\begin{array}{l}\text { 3.1 Economic: } \\
\text { - size (employees) } \\
\text { - capital intensity } \\
\text { - productivity (labour } \\
\text { productivity) } \\
\text { 3.2 Human capital and } \\
\text { innovation: } \\
\text { - dummy for product innovation } \\
\text { - dummy for process } \\
\text { innovation } \\
\text { 3.3 Financial: } \\
\text { - n. of banks } \\
\text { - cash stock }\end{array}$ & $\begin{array}{l}\text { 4.1 Data: } \\
\text { - Type: manufacturing sector, } \\
\text { single-country analysis } \\
\text { - Source: Capitalia (1998-2000; } \\
\text { 2001-2003) } \\
\text { 4.2 Empirical strategy: } \\
\text { - Econometric analysis: } \\
\text { regressions (cross-section: } \\
\text { Probit, Poisson) }\end{array}$ & $\begin{array}{l}\text { 5.1 Direction: } \\
\text { - self-selection } \\
\text { - learning-by- } \\
\text { internationalisation } \\
\text { 5.2 Econometric tools: } \\
\text { none } \\
\text { - explicit test for causality } \\
\text { Bernard and Jensen } \\
\text { methodology; support to self- } \\
\text { selection) }\end{array}$ & $\begin{array}{l}\text { 6.1 Common patterns } \\
\text { Financial market } \\
\text { 6.2 Degree of } \\
\text { internationalisation: } \\
\text { none } \\
\text { 6.3 Performance } \\
\text { premiums/discounts: } \\
\text { Cash stock is positively } \\
\text { correlated with the export } \\
\text { probability and the number of } \\
\text { destinations only for the } \\
\text { constrained firms. }\end{array}$ \\
\hline $\begin{array}{l}\text { Frazzoni et al. } \\
\text { (2011) }\end{array}$ & $\begin{array}{l}\text { 2.1 Categories of } \\
\text { international involvement: } \\
\text { - export (status; intensity) } \\
\text { 2.2 Comparison strategy: } \\
\text { One variable for each category, } \\
\text { to compare international } \\
\text { enterprises with themselves } \\
\text { and with domestic players. }\end{array}$ & $\begin{array}{l}\text { 3.1 Economic: } \\
\text { - value added } \\
\text { - capital } \\
\text { - age } \\
\text { - group affiliation } \\
\text { 3.2 Human capital and } \\
\text { innovation: } \\
\text { - dummy for product innovation } \\
\text { - dummy for process } \\
\text { innovation } \\
\text { 3.3 Financial: } \\
\text { - strength of the relationship } \\
\text { between the firm and its main } \\
\text { bank }\end{array}$ & $\begin{array}{l}\text { 4.1 Data: } \\
\text { - Type: manufacturing sector, } \\
\text { single-country analysis } \\
\text { - Source: Capitalia (2004- } \\
\text { 2006) } \\
\text { 4.2 Empirical strategy: } \\
\text { - Econometric analysis: } \\
\text { regressions (cross-section: } \\
\text { FIML-IV Probit) }\end{array}$ & $\begin{array}{l}\text { 5.1 Direction: } \\
\text { - self-selection } \\
5.2 \text { Econometric tools: } \\
\text { none }\end{array}$ & $\begin{array}{l}\text { 6.1 Common patterns } \\
\text { Financial market } \\
\text { 6.2 Degree of } \\
\text { internationalisation: } \\
\text { none } \\
6.3 \text { Performance } \\
\text { premiums/discounts: } \\
\text { Product innovation and the } \\
\text { strength of the relationship } \\
\text { between the firm and its main } \\
\text { bank are positively correlated } \\
\text { with the export status and } \\
\text { intensity. }\end{array}$ \\
\hline
\end{tabular}




\begin{tabular}{|c|c|c|c|c|c|}
\hline $\begin{array}{l}\text { Giovannetti et al. } \\
(2009)\end{array}$ & $\begin{array}{l}\text { 2.1 Categories of } \\
\text { international involvement: } \\
\text { - export (status) } \\
\text { - FDI (status) } \\
\text { 2.2 Comparison strategy: } \\
\text { One variable for each category, } \\
\text { to compare international } \\
\text { enterprises with themselves } \\
\text { and with domestic players. }\end{array}$ & $\begin{array}{l}\text { 3.1 Economic: } \\
\text { - survival probability } \\
\text { 3.2 Human capital and } \\
\text { innovation: } \\
\text { none } \\
\text { 3.3 Financial: } \\
\text { none }\end{array}$ & $\begin{array}{l}\text { 4.1 Data: } \\
\text { - Type: manufacturing sector, } \\
\text { single-country analysis } \\
\text { - Source: } \\
\text { Capitalia (2001-2003) + Ice } \\
\text { Reprint (2001) } \\
\text { 4.2 Empirical strategy: } \\
\text { - Econometric analysis: } \\
\text { regressions (cross-section: } \\
\text { duration analysis, Cox } \\
\text { proportional hazard } \\
\text { regressions) }\end{array}$ & $\begin{array}{l}\text { 5.1 Direction: } \\
\text { - learning-by- } \\
\text { internationalisation } \\
5.2 \text { Econometric tools: } \\
\text { none }\end{array}$ & $\begin{array}{l}\text { 6.1 Common patterns } \\
\text { Innovation } \\
6.2 \text { Degree of } \\
\text { internationalisation: } \\
\text { Exporters are the majority } \\
(75 \%) \text {. Firms engaged in FDI } \\
\text { are the minority (11\%). } \\
6.3 \text { Performance } \\
\text { premiums/discounts: } \\
\text { Internationalisation is positively } \\
\text { correlated with firms' survival } \\
\text { probability. Large } \\
\text { internationalised firms are more } \\
\text { likely to survive. }\end{array}$ \\
\hline $\begin{array}{l}\text { Giovannetti et al. } \\
(2013)\end{array}$ & $\begin{array}{l}\text { 2.1 Categories of } \\
\text { international involvement: } \\
\text { - export (status; status of } \\
\text { exporters to EU25) } \\
\text { - FDI (status) } \\
\text { 2.2 Comparison strategy: } \\
\text { One variable for each category, } \\
\text { to compare international } \\
\text { enterprises with themselves } \\
\text { and with domestic players. }\end{array}$ & $\begin{array}{l}\text { 3.1 Economic: } \\
\text { - size (sales) } \\
\text { 3.2 Human capital and } \\
\text { innovation: } \\
\text { none } \\
\text { 3.3 Financial: } \\
\text { none }\end{array}$ & $\begin{array}{l}\text { 4.1 Data: } \\
\text { - Type: manufacturing sector, } \\
\text { single-country analysis } \\
\text { - Source: Capitalia (2001- } \\
\text { 2003) + Ice Reprint (2001) } \\
\text { 4.2 Empirical strategy: } \\
\text { - Econometric analysis: } \\
\text { regressions (cross-section: } \\
\text { cross sectional time series non } \\
\text { linear model with GLS) }\end{array}$ & $\begin{array}{l}\text { 5.1 Direction: } \\
\text { - learning-by- } \\
\text { internationalisation } \\
5.2 \text { Econometric tools: } \\
\text { none }\end{array}$ & $\begin{array}{l}\text { 6.1 Common patterns } \\
\text { Not only export } \\
\text { 6.2 Degree of } \\
\text { internationalisation: } \\
\text { Exporters are the majority } \\
\text { (75\%). Firms engaged in FDI } \\
\text { are the minority (11\%). } \\
6.3 \text { Performance } \\
\text { premiums/discounts: } \\
\text { Firms engaged in international } \\
\text { operations of any kind are larger } \\
\text { than domestic players. }\end{array}$ \\
\hline $\begin{array}{l}\text { Giunta and Scalera } \\
\text { (2007) }\end{array}$ & $\begin{array}{l}\text { 2.1 Categories of } \\
\text { international involvement: } \\
\text { - subcontracting (intensity) } \\
2.2 \text { Comparison strategy: } \\
\text { One variable for each category, } \\
\text { to compare international } \\
\text { enterprises with themselves } \\
\text { and with domestic players. }\end{array}$ & $\begin{array}{l}\text { 3.1 Economic: } \\
\text { - productivity (labour } \\
\text { productivity) } \\
\text { - value added per capital } \\
\text { - wage } \\
\text { 3.2 Human capital and } \\
\text { innovation: } \\
\text { none } \\
\text { 3.3 Financial: } \\
\text { - ROI }\end{array}$ & $\begin{array}{l}\text { 4.1 Data: } \\
\text { - Type: manufacturing sector, } \\
\text { single-country analysis } \\
\text { - Source: Capitalia (1995-1997; } \\
\text { 1998-2000) } \\
\text { 4.2 Empirical strategy: } \\
\text { - Descriptive statistics } \\
\text { - Econometric analysis: } \\
\text { regressions (cross-section: } \\
\text { OLS, GMM) }\end{array}$ & $\begin{array}{l}\text { 5.1 Direction: } \\
\text { - learning-by- } \\
\text { internationalisation } \\
5.2 \text { Econometric tools: } \\
\text { none }\end{array}$ & $\begin{array}{l}\text { 6.1 Common patterns } \\
\text { Not only export } \\
\text { 6.2 Degree of } \\
\text { internationalisation: } \\
\text { none } \\
6.3 \text { Performance } \\
\text { premiums/discounts: } \\
\text { Subcontracting is positively } \\
\text { correlated with firms' } \\
\text { performance indicators. } \\
\text { However, it is negatively } \\
\text { correlated with productivity, } \\
\text { wage and value added per } \\
\text { capital for firms located in the } \\
\text { South. } \\
\end{array}$ \\
\hline Grazzi (2012) & $\begin{array}{l}\text { 2.1 Categories of } \\
\text { international involvement: } \\
\text { - export (status; status of } \\
\text { occasional exporter; status of } \\
\text { systematic exporter) } \\
2.2 \text { Comparison strategy: } \\
\text { One variable for each category, } \\
\text { to compare international }\end{array}$ & $\begin{array}{l}\text { 3.1 Economic: } \\
\text { - productivity (labour } \\
\text { productivity; TFP) } \\
\text { - size (sales; growth rate of } \\
\text { sales) } \\
\text { 3.2 Human capital and } \\
\text { innovation: } \\
\text { none }\end{array}$ & $\begin{array}{l}\text { 4.1 Data: } \\
\text { - Type: manufacturing sector, } \\
\text { single-country analysis } \\
\text { - Source: Micro3 + COE (1989- } \\
\text { 2004) } \\
\text { 4.2 Empirical strategy: } \\
\text { - Descriptive statistics } \\
\text { - Econometric analysis: }\end{array}$ & $\begin{array}{l}\text { 5.1 Direction: } \\
\text { - self-selection } \\
\text { 5.2 Econometric tools: } \\
\text { none }\end{array}$ & $\begin{array}{l}\text { 6.1 Common patterns } \\
\text { Financial market } \\
6.2 \text { Degree of } \\
\text { internationalisation: } \\
\text { Exporters are the majority in } \\
\text { many sectors. The share of } \\
\text { exporters by sector has } \\
\text { increased over time. There is a }\end{array}$ \\
\hline
\end{tabular}




\begin{tabular}{|c|c|c|c|c|c|}
\hline & $\begin{array}{l}\text { enterprises with themselves } \\
\text { and with domestic players. }\end{array}$ & $\begin{array}{l}\text { 3.3 Financial: } \\
\text { - ROS }\end{array}$ & $\begin{array}{l}\text { regressions (panel: pooled } \\
\text { OLS, random effects); non } \\
\text { parametric analysis (Fligner- } \\
\text { Policello) }\end{array}$ & & $\begin{array}{l}\text { strong persistence in the export } \\
\text { status by sector. } \\
6.3 \text { Performance } \\
\text { premiums/discounts: } \\
\text { Exporters are larger and more } \\
\text { productive than non-exporters; } \\
\text { nevertheless there is no clear } \\
\text { evidence of a superior } \\
\text { performance in terms of } \\
\text { profitability and growth for } \\
\text { exporting firms. }\end{array}$ \\
\hline Imbruno (2008a) & $\begin{array}{l}\text { 2.1 Categories of } \\
\text { international involvement: } \\
\text { - export (status; intensity) } \\
2.2 \text { Comparison strategy: } \\
\text { One variable for each category, } \\
\text { to compare international } \\
\text { enterprises with themselves } \\
\text { and with domestic players. }\end{array}$ & $\begin{array}{l}\text { 3.1 Economic: } \\
\text { - productivity (labour } \\
\text { productivity) } \\
\text { 3.2 Human capital and } \\
\text { innovation: } \\
\text { none } \\
\text { 3.3 Financial: } \\
\text { none }\end{array}$ & $\begin{array}{l}\text { 4.1 Data: } \\
\text { - Type: manufacturing sector, } \\
\text { single-country analysis } \\
\text { - Source: (Capitalia 1998-2000; } \\
\text { 2001-2003) } \\
\text { 4.2 Empirical strategy: } \\
\text { - Descriptive statistics } \\
\text { - Econometric analysis: } \\
\text { regressions (panel: Pooled, } \\
\text { OLS, fixed effects, random } \\
\text { effects) }\end{array}$ & $\begin{array}{l}\text { 5.1 Direction: } \\
\text { - self-selection } \\
\text { - learning-by- } \\
\text { internationalisation } \\
\text { 5.2 Econometric tools: } \\
\text { - explicit test for causality } \\
\text { Bernard and Jensen } \\
\text { methodology; support to self- } \\
\text { selection) }\end{array}$ & $\begin{array}{l}\text { 6.1 Common patterns } \\
\text { Causal links between export } \\
\text { and productivity } \\
6.2 \text { Degree of } \\
\text { internationalisation: } \\
\text { Exporters are the majority (more } \\
\text { than } 70 \% \text { ). } \\
\text { 6.3 Performance } \\
\text { premiums/discounts: } \\
\text { Exporters are more productive } \\
\text { than domestic enterprises. }\end{array}$ \\
\hline Imbruno (2008b) & $\begin{array}{l}\text { 2.1 Categories of } \\
\text { international involvement: } \\
\text { - export (status; intensity) } \\
2.2 \text { Comparison strategy: } \\
\text { One variable for each category, } \\
\text { to compare international } \\
\text { enterprises with themselves } \\
\text { and with domestic players. }\end{array}$ & $\begin{array}{l}\text { 3.1 Economic: } \\
\text { - productivity (labour } \\
\text { productivity) } \\
\text { 3.2 Human capital and } \\
\text { innovation: } \\
\text { none } \\
\text { 3.3 Financial: } \\
\text { none }\end{array}$ & $\begin{array}{l}\text { 4.1 Data: } \\
\text { - Type: manufacturing sector, } \\
\text { single-country analysis } \\
\text { - Source: Capitalia (1998-2000; } \\
\text { 2001-2003) } \\
\text { 4.2 Empirical strategy: } \\
\text { - Descriptive statistics } \\
\text { - Econometric analysis: } \\
\text { regressions (panel: Pooled, } \\
\text { OLS, fixed effects, random } \\
\text { effects) }\end{array}$ & $\begin{array}{l}\text { 5.1 Direction: } \\
\text { - learning-by- } \\
\text { internationalisation } \\
5.2 \text { Econometric tools: } \\
\text { none }\end{array}$ & $\begin{array}{l}\text { 6.1 Common patterns } \\
\text { Causal links between export } \\
\text { and productivity } \\
6.2 \text { Degree of } \\
\text { internationalisation: } \\
\text { Exporters are the majority (more } \\
\text { than } 70 \% \text { ). } \\
\text { 6.3 Performance } \\
\text { premiums/discounts: } \\
\text { Export status and export } \\
\text { intensity have a positive impact } \\
\text { on firms' productivity, and this } \\
\text { effect is larger the more } \\
\text { integrated the geographical } \\
\text { area. }\end{array}$ \\
\hline ISGEP (2008) & $\begin{array}{l}\text { 2.1 Categories of } \\
\text { international involvement: } \\
\text { - export (status; intensity) } \\
2.2 \text { Comparison strategy: } \\
\text { One variable for each category, } \\
\text { to compare international } \\
\text { enterprises with themselves } \\
\text { and with domestic players. }\end{array}$ & $\begin{array}{l}\text { 3.1 Economic: } \\
\text { - size (sales per employee) } \\
\text { - productivity (labour } \\
\text { productivity; TFP) } \\
\text { 3.2 Human capital and } \\
\text { innovation: } \\
\text { none } \\
\text { 3.3 Financial: } \\
\text { none }\end{array}$ & $\begin{array}{l}\text { 4.1 Data: } \\
\text { - Type: manufacturing sector, } \\
\text { cross-country analysis (Austria, } \\
\text { Belgium, Chile, China, } \\
\text { Colombia, Denmark, France, } \\
\text { Germany, Italy, Ireland, } \\
\text { Slovenia, Spain, Sweden, UK) } \\
\text { - Source: } \\
\text { (for Italy) Micro1 (1989-1997) } \\
\text { + COE (1993-1997) } \\
\text { 4.2 Empirical strategy: } \\
\text { - Descriptive statistics }\end{array}$ & $\begin{array}{l}\text { 5.1 Direction: } \\
\text { - self-selection } \\
\text { - learning-by- } \\
\text { internationalisation } \\
\text { 5.2 Econometric tools: } \\
\text { - explicit test for causality } \\
\text { (Bernard and Jensen } \\
\text { methodology; support to self- } \\
\text { selection in all countries, to } \\
\text { learning-by-internationalisation } \\
\text { only in Italy) }\end{array}$ & $\begin{array}{l}\text { 6.1 Common patterns } \\
\text { Italy vis-à-vis with the rest of the } \\
\text { world } \\
\mathbf{6 . 2} \text { Degree of } \\
\text { internationalisation: } \\
\text { Exporters are the majority ( } 69 \% \\
\text { in Italy). Export is concentrated } \\
\text { in the hands of top } 1 \% \text {, top } 5 \% \\
\text { and top } 10 \% \text { of exporters. } \\
\mathbf{6 . 3} \text { Performance } \\
\text { premiums/discounts: } \\
\text { Exporters are more productive }\end{array}$ \\
\hline
\end{tabular}




\begin{tabular}{|c|c|c|c|c|c|}
\hline & & & $\begin{array}{l}\text { - Econometric analysis: } \\
\text { regressions: (cross-section: } \\
\text { Logit; panel: Pooled OLS, fixed } \\
\text { effects) }\end{array}$ & & $\begin{array}{l}\text { than domestic firms. } \\
\text { Productivity premiums increase } \\
\text { with export intensity in all } \\
\text { countries. However, they are } \\
\text { larger the lower the participation } \\
\text { rates and GDP per capita, the } \\
\text { more restrictive the trade } \\
\text { policies, the less effective the } \\
\text { government, the worse the } \\
\text { regulatory quality and the more } \\
\text { distant the destination market. }\end{array}$ \\
\hline $\begin{array}{l}\text { Lo Turco and } \\
\text { Maggioni (2012) }\end{array}$ & $\begin{array}{l}\text { 2.1 Categories of } \\
\text { international involvement: } \\
\text { - offshoring (intensity of } \\
\text { offshoring from high-income } \\
\text { countries; intensity of } \\
\text { offshoring from low-income } \\
\text { countries) } \\
2.2 \text { Comparison strategy: } \\
\text { One variable for each category, } \\
\text { to compare international } \\
\text { enterprises with themselves } \\
\text { and with domestic players. }\end{array}$ & $\begin{array}{l}\text { 3.1 Economic: } \\
\text { - size (employees) } \\
\text { 3.2 Human capital and } \\
\text { innovation: } \\
\text { none } \\
\text { 3.3 Financial: } \\
\text { none }\end{array}$ & $\begin{array}{l}\text { 4.1 Data: } \\
\text { - Type: manufacturing sector, } \\
\text { single-country analysis } \\
\text { - Source: ASIA + COE (2000- } \\
\text { 2004) } \\
\text { 4.2 Empirical strategy: } \\
\text { - Econometric analysis: } \\
\text { regressions (panel: GMM-SYS) }\end{array}$ & $\begin{array}{l}\text { 5.1 Direction: } \\
\text { - learning-by- } \\
\text { internationalisation } \\
5.2 \text { Econometric tools: } \\
\text { none }\end{array}$ & $\begin{array}{l}\text { 6.1 Common patterns } \\
\text { Labour market } \\
6.2 \text { Degree of } \\
\text { internationalisation: } \\
\text { Offshoring firms are the minority } \\
\text { (37\% in 2000). Offshoring to } \\
\text { high-income countries is still } \\
\text { more common than offshoring } \\
\text { to low-income countries; } \\
\text { however it has declined over } \\
\text { time. } \\
6.3 \text { Performance } \\
\text { premiums/discounts: } \\
\text { Offshoring to low-income } \\
\text { countries has a negative effect } \\
\text { on firm size in traditional } \\
\text { sectors. }\end{array}$ \\
\hline $\begin{array}{l}\text { Macis and Schivardi } \\
\text { (2012) }\end{array}$ & $\begin{array}{l}\text { 2.1 Categories of } \\
\text { international involvement: } \\
\text { - export (intensity) } \\
\text { 2.2 Comparison strategy: } \\
\text { One variable for each category, } \\
\text { to compare international } \\
\text { enterprises with themselves } \\
\text { and with domestic players. }\end{array}$ & $\begin{array}{l}\text { 3.1 Economic: } \\
\text { - wage } \\
\text { 3.2 Human capital and } \\
\text { innovation: } \\
\text { none } \\
\text { 3.3 Financial: } \\
\text { none }\end{array}$ & $\begin{array}{l}\text { 4.1 Data: } \\
\text { - Type: manufacturing sector, } \\
\text { single-country analysis } \\
\text { - Source: Invind (1987-1997) + } \\
\text { INPS (1980-1997) } \\
\text { 4.2 Empirical strategy: } \\
\text { - Econometric analysis: } \\
\text { regressions (panel: OLS, fixed } \\
\text { effects) }\end{array}$ & $\begin{array}{l}\text { 5.1 Direction: } \\
\text { - learning-by- } \\
\text { internationalisation } \\
\text { 5.2 Econometric tools: } \\
\text { none }\end{array}$ & $\begin{array}{l}\text { 6.1 Common patterns } \\
\text { Labour market } \\
6.2 \text { Degree of } \\
\text { internationalisation: } \\
\text { none } \\
6.3 \text { Performance } \\
\text { premiums/discounts: } \\
\text { Export intensity positively } \\
\text { affects wages, because of the } \\
\text { joint effect of skill composition } \\
\text { and rent sharing. }\end{array}$ \\
\hline $\begin{array}{l}\text { Manasse et al. } \\
(2004)\end{array}$ & $\begin{array}{l}\text { 2.1 Categories of } \\
\text { international involvement: } \\
\text { - export (status) } \\
\text { 2.2 Comparison strategy: } \\
\text { One variable for each category, } \\
\text { to compare international } \\
\text { enterprises with themselves } \\
\text { and with domestic players. }\end{array}$ & $\begin{array}{l}\text { 3.1 Economic: } \\
\text { - wage } \\
\text { - wage of white collar } \\
\text { employees } \\
\text { - wage premium } \\
\text { - size (employees) } \\
\text { 3.2 Human capital and } \\
\text { innovation: } \\
\text { - share of white collar } \\
\text { employees }\end{array}$ & $\begin{array}{l}\text { 4.1 Data: } \\
\text { - Type: manufacturing sector, } \\
\text { single-country analysis } \\
\text { - Source: Federmeccanica } \\
\text { (1995-1997) } \\
\text { 4.2 Empirical strategy: } \\
\text { - Descriptive statistics } \\
\text { - Econometric analysis: } \\
\text { regressions (panel: OLS) }\end{array}$ & $\begin{array}{l}\text { 5.1 Direction: } \\
\text { - learning-by- } \\
\text { internationalisation } \\
5.2 \text { Econometric tools: } \\
\text { none }\end{array}$ & $\begin{array}{l}\text { 6.1 Common patterns } \\
\text { Labour market } \\
6.2 \text { Degree of } \\
\text { internationalisation: } \\
\text { none } \\
6.3 \text { Performance } \\
\text { premiums/discounts: } \\
\text { Technology and export have } \\
\text { affected the wage premium and } \\
\text { factor proportions in opposite }\end{array}$ \\
\hline
\end{tabular}




\begin{tabular}{|c|c|c|c|c|c|}
\hline & & $\begin{array}{l}\text { 3.3 Financial: } \\
\text { none }\end{array}$ & & & $\begin{array}{l}\text { directions, thus offsetting each } \\
\text { other. On the one hand, skill- } \\
\text { biased technical progress raised } \\
\text { the relative demand for skilled } \\
\text { labour within firms. On the other } \\
\text { hand, trade related changes } \\
\text { reduced the relative demand for } \\
\text { skills, shifting employment away } \\
\text { from skill intensive firms. }\end{array}$ \\
\hline $\begin{array}{l}\text { Manasse and Stanca } \\
\text { (2006) }\end{array}$ & $\begin{array}{l}\text { 2.1 Categories of } \\
\text { international involvement: } \\
\text { - export (status of "high" } \\
\text { exporter, i.e. firms whose } \\
\text { export intensity is above the } \\
\text { median; status of "low" } \\
\text { exporter, i.e. firms whose } \\
\text { export intensity is below the } \\
\text { median) } \\
\text { 2.2 Comparison strategy: } \\
\text { One variable for each category, } \\
\text { to compare international } \\
\text { enterprises with themselves } \\
\text { and with domestic players. }\end{array}$ & $\begin{array}{l}\text { 3.1 Economic: } \\
\text { - wage } \\
\text { - wage of white collar } \\
\text { employees } \\
\text { - wage premium } \\
\text { - size (employees) } \\
\text { 3.2 Human capital and } \\
\text { innovation: } \\
\text { - share of white collar } \\
\text { employees } \\
\text { - dummy for high tech firms } \\
\text { - dummy for low tech firms } \\
\text { 3.3 Financial: } \\
\text { none }\end{array}$ & $\begin{array}{l}\text { 4.1 Data: } \\
\text { - Type: manufacturing sector, } \\
\text { single-country analysis } \\
\text { - Source: SISSI (1989-1995) } \\
\text { 4.2 Empirical strategy: } \\
\text { - Descriptive statistics } \\
\text { - Econometric analysis: } \\
\text { regressions (panel: OLS) }\end{array}$ & $\begin{array}{l}\text { 5.1 Direction: } \\
\text { - learning-by- } \\
\text { internationalisation } \\
\text { 5.2 Econometric tools: } \\
\text { none }\end{array}$ & $\begin{array}{l}\text { 6.1 Common patterns } \\
\text { Labour market } \\
6.2 \text { Degree of } \\
\text { internationalisation: } \\
\text { none } \\
6.3 \text { Performance } \\
\text { premiums/discounts: } \\
\text { High and low exporters pay } \\
\text { similar wages and have similar } \\
\text { skill intensity on the aggregate. } \\
\text { However, controlling for size, } \\
\text { these similarities vanish: small } \\
\text { and medium high exporters are } \\
\text { more skill intensive and pay } \\
\text { lower wages than low exporters } \\
\text { of the same size, while the } \\
\text { converse is true for high } \\
\text { exporters. Furthermore, } \\
\text { demand changes associated } \\
\text { with trade have moved } \\
\text { employment away from skill } \\
\text { intensive firms. }\end{array}$ \\
\hline $\begin{array}{l}\text { Mayer and Ottaviano } \\
(2008)\end{array}$ & $\begin{array}{l}2.1 \text { Categories of } \\
\text { international involvement: } \\
\text { - export (value; status; } \\
\text { intensity; } n \text {. of destinations; } n \text {. } \\
\text { of exported goods; n. of foreign } \\
\text { clients) } \\
\text { - FDI (status) } \\
2.2 \text { Comparison strategy: } \\
\text { One variable for each category, } \\
\text { to compare international } \\
\text { enterprises with themselves } \\
\text { and with domestic players. }\end{array}$ & $\begin{array}{l}\text { 3.1 Economic: } \\
\text { - productivity (labour } \\
\text { productivity; TFP) } \\
\text { - size (employees) } \\
\text { - capital intensity } \\
\text { - wage } \\
\text { - value added } \\
\text { 3.2 Human capital and } \\
\text { innovation: } \\
\text { - share of white collar } \\
\text { employees } \\
\text { 3.3 Financial: } \\
\text { none }\end{array}$ & $\begin{array}{l}\text { 4.1 Data: } \\
\text { - Type: manufacturing sector, } \\
\text { cross-country analysis } \\
\text { (Belgium, Germany, France, } \\
\text { Hungary, Italy, Norway, UK) } \\
\text { - Source: } \\
\text { (for Italy) Capitalia (1998-2000; } \\
\text { 2001-2003) } \\
\text { 4.2 Empirical strategy: } \\
\text { - Descriptive statistics }\end{array}$ & $\begin{array}{l}\text { 5.1 Direction: } \\
\text { - learning-by- } \\
\text { internationalisation } \\
\text { 5.2 Econometric tools: } \\
\text { none }\end{array}$ & $\begin{array}{l}\text { 6.1 Common patterns } \\
\text { Italy vis-à-vis with the rest of the } \\
\text { world } \\
6.2 \text { Degree of } \\
\text { internationalisation: } \\
\text { Exporters are the minority in all } \\
\text { the sampled countries, except } \\
\text { for Italy. Export is concentrated } \\
\text { in the hands of large exporters } \\
\text { (defined in terms of value, } \\
\text { intensity, n. of foreign clients } \\
\text { and n. of destinations). } \\
6.3 \text { Performance } \\
\text { premiums/discounts: } \\
\text { Exporters and firms engaged in } \\
\text { FDI are better than domestic } \\
\text { players, with respect to all } \\
\text { performance indicators. }\end{array}$ \\
\hline
\end{tabular}




\begin{tabular}{|c|c|c|c|c|c|}
\hline & & & & & $\begin{array}{l}\text { Moreover, firms engaged in FDI } \\
\text { are more productive than } \\
\text { exporters which, in turn, are } \\
\text { more productive than domestic } \\
\text { players. }\end{array}$ \\
\hline $\begin{array}{l}\text { Minetti and Zhu } \\
\text { (2011) }\end{array}$ & $\begin{array}{l}\text { 2.1 Categories of } \\
\text { international involvement: } \\
\text { - export (status; value) } \\
\text { 2.2 Comparison strategy: } \\
\text { One variable for each category, } \\
\text { to compare international } \\
\text { enterprises with themselves } \\
\text { and with domestic players. }\end{array}$ & $\begin{array}{l}\text { 3.1 Economic: } \\
\text { - productivity (labour } \\
\text { productivity) } \\
\text { - size (employees) } \\
\text { - capital intensity } \\
\text { 3.2 Human capital and } \\
\text { innovation: } \\
\text { - share of graduates } \\
\text { - share of employment with } \\
\text { secondary education } \\
\text { 3.3 Financial: } \\
\text { - strong credit rationing } \\
\text { - weak credit rationing } \\
\text { - liquidity ratio } \\
\text { - leverage ratio } \\
\text { - cash flow }\end{array}$ & $\begin{array}{l}\text { 4.1 Data: } \\
\text { - Type: manufacturing sector, } \\
\text { single-country analysis } \\
\text { - Source: Capitalia (1998- } \\
\text { 2000) } \\
\text { 4.2 Empirical strategy: } \\
\text { - Descriptive statistics } \\
\text { - Econometric analysis: } \\
\text { regressions (cross-section: } \\
\text { Probit, Bivariate Probit, OLS, } \\
\text { 2SLS) }\end{array}$ & $\begin{array}{l}\text { 5.1 Direction: } \\
\text { - self-selection } \\
5.2 \text { Econometric tools: } \\
\text { none }\end{array}$ & $\begin{array}{l}\text { 6.1 Common patterns } \\
\text { Financial market } \\
\text { 6.2 Degree of } \\
\text { internationalisation: } \\
\text { none } \\
6.3 \text { Performance } \\
\text { premiums/discounts: } \\
\text { Credit rationing is negatively } \\
\text { correlated with the export } \\
\text { probability and export value. } \\
\text { This effect is stronger for firms } \\
\text { operating in high tech } \\
\text { industries, firms exporting to a } \\
\text { single market or a non-EU } \\
\text { market and firms with shorter } \\
\text { credit relationship or with fewer } \\
\text { bank contacts. }\end{array}$ \\
\hline Morone et al. (2011) & $\begin{array}{l}\text { 2.1 Categories of } \\
\text { international involvement: } \\
\text { - export (status of future } \\
\text { exporter) } \\
\text { 2.2 Comparison strategy: } \\
\text { One variable for each category, } \\
\text { to compare international } \\
\text { enterprises with themselves } \\
\text { and with domestic players. }\end{array}$ & $\begin{array}{l}\text { 3.1 Economic: } \\
\text { - size (sales) } \\
\text { - age } \\
\text { 3.2 Human capital and } \\
\text { innovation: } \\
\text { - product innovation } \\
\text { - process innovation } \\
\text { - organizational innovation } \\
\text { - marketing innovation } \\
\text { 3.3 Financial: } \\
\text { none }\end{array}$ & $\begin{array}{l}\text { 4.1 Data: } \\
\text { - Type: manufacturing sector, } \\
\text { single-country analysis } \\
\text { - Source: Indagine Tagliacarne } \\
\text { (2004) } \\
\text { 4.2 Empirical strategy: } \\
\text { - Descriptive statistics } \\
\text { - Econometric analysis: } \\
\text { regressions (cross-section: } \\
\text { multinomial logit, PSM) }\end{array}$ & $\begin{array}{l}\text { 5.1 Direction: } \\
\text { - self-selection } \\
\text { 5.2 Econometric tools: } \\
\text { - explicit test for causality; PSM } \\
\text { with performance in the } \\
\text { treatment) }\end{array}$ & $\begin{array}{l}\text { 6.1 Common patterns } \\
\text { Innovation } \\
6.2 \text { Degree of } \\
\text { internationalisation: } \\
\text { Future exporters are the } \\
\text { minority (26\%). } \\
6.3 \text { Performance } \\
\text { premiums/discounts: } \\
\text { Firms engaged in non-technical } \\
\text { innovations are more likely to } \\
\text { look for new export markets in } \\
\text { the future than firms engaged in } \\
\text { technical innovations. Firms } \\
\text { performing both types of } \\
\text { innovation benefit from the } \\
\text { highest probability of entering } \\
\text { foreign markets in the future. }\end{array}$ \\
\hline Nassimbeni (2001) & $\begin{array}{l}\text { 2.1 Categories of } \\
\text { international involvement: } \\
\text { - export (status; intensity) } \\
\text { 2.2 Comparison strategy: } \\
\text { One variable for each category, } \\
\text { to compare international } \\
\text { enterprises with themselves } \\
\text { and with domestic players. }\end{array}$ & $\begin{array}{l}\text { 3.1 Economic: } \\
\text { - size (employees) } \\
\text { - age } \\
\text { - consortium affiliation } \\
\text { - type of customers (dummy for } \\
\text { utilization of external services; } \\
\text { percentage of sales to } \\
\text { commercial agents or firms) } \\
\text { 3.2 Human capital and } \\
\text { innovation: }\end{array}$ & $\begin{array}{l}\text { 4.1 Data: } \\
\text { - Type: manufacturing sector, } \\
\text { single-country analysis } \\
\text { - Source: Survey on } \\
\text { technology, innovation and } \\
\text { export in Friuli-Venezia Giulia } \\
\text { 4.2 Empirical strategy: } \\
\text { - Descriptive statistics } \\
\text { - Econometric analysis: } \\
\text { regressions (cross-section: }\end{array}$ & $\begin{array}{l}\text { 5.1 Direction: } \\
\text { - self-selection } \\
5.2 \text { Econometric tools: } \\
\text { none }\end{array}$ & $\begin{array}{l}\text { 6.1 Common patterns } \\
\text { Innovation } \\
6.2 \text { Degree of } \\
\text { internationalisation: } \\
\text { Exporters are the minority } \\
\text { (45\%) of Italian SMEs located in } \\
\text { Friuli-Venezia Giulia and } \\
\text { operating in the furniture, } \\
\text { mechanics and electro- } \\
\text { electronic sectors. }\end{array}$ \\
\hline
\end{tabular}




\begin{tabular}{|c|c|c|c|c|c|}
\hline & & $\begin{array}{l}\text { - level of technological avant- } \\
\text { garde } \\
\text { - level of product innovation } \\
\text { - planned investment in } \\
\text { innovation over the next } 5 \\
\text { years } \\
\text { 3.3 Financial: } \\
\text { none }\end{array}$ & OLS, Logit, Tobit) & & $\begin{array}{l}6.3 \text { Performance } \\
\text { premiums/discounts: } \\
\text { Export is positively associated } \\
\text { with size, product innovation } \\
\text { and the ability to develop valid } \\
\text { inter-organizational relations, } \\
\text { while technology and process } \\
\text { innovation play only a marginal } \\
\text { role. }\end{array}$ \\
\hline $\begin{array}{l}\text { Pappalardo and } \\
\text { Vicarelli (2012) }\end{array}$ & $\begin{array}{l}\text { 2.1 Categories of } \\
\text { international involvement: } \\
\text { - export (value; } \mathrm{n} \text {. of exported } \\
\text { goods by destination; } \mathrm{n} \text {. of } \\
\text { exported goods) } \\
\text { 2.2 Comparison strategy: } \\
\text { One variable for each category, } \\
\text { to compare international } \\
\text { enterprises with themselves } \\
\text { and with domestic players. }\end{array}$ & $\begin{array}{l}\text { 3.1 Economic: } \\
\text { - productivity (labour } \\
\text { productivity) } \\
\text { - size (employees) } \\
\text { 3.2 Human capital and } \\
\text { innovation: } \\
\text { none } \\
\text { 3.3 Financial: } \\
\text { - dummy for Euro introduction }\end{array}$ & $\begin{array}{l}\text { 4.1 Data: } \\
\text { - Type: manufacturing sector, } \\
\text { single-country analysis } \\
\text { - Source: Micro3 + COE (1996- } \\
\text { 2004) } \\
\text { 4.2 Empirical strategy: } \\
\text { - Descriptive statistics } \\
\text { - Econometric analysis: } \\
\text { regressions (panel: Gravity } \\
\text { model, DID, OLS, fixed effects) }\end{array}$ & $\begin{array}{l}5.1 \text { Direction: } \\
\text { - self-selection } \\
5.2 \text { Econometric tools: } \\
\text { none }\end{array}$ & $\begin{array}{l}\text { 6.1 Common patterns } \\
\text { Financial market } \\
\text { 6.2 Degree of } \\
\text { internationalisation: } \\
\text { Exporters are the majority over } \\
\text { the whole period of time. Firms } \\
\text { exporting many products to } \\
\text { many markets are more than } \\
\text { firms serving just one foreign } \\
\text { market. } 6.3 \text { Performance } \\
\text { premiums/discounts: } \\
\text { The introduction of Euro has } \\
\text { positively affected the Italian } \\
\text { overall exports. This effect was } \\
\text { crucially driven by the change in } \\
\text { the } n \text {. of exported goods, rather } \\
\text { than the change in the } \mathrm{n} \text {. of } \\
\text { exported goods by destination. }\end{array}$ \\
\hline $\begin{array}{l}\text { Piva and Vivarelli } \\
\text { (2001) }\end{array}$ & $\begin{array}{l}\text { 2.1 Categories of } \\
\text { international involvement: } \\
\text { - FDI (status) } \\
\text { 2.2 Comparison strategy: } \\
\text { One variable for each category, } \\
\text { to compare international } \\
\text { enterprises with themselves } \\
\text { and with domestic players. }\end{array}$ & $\begin{array}{l}\text { 3.1 Economic: } \\
\text { - number of white collar } \\
\text { employees } \\
\text { - number of blue collar } \\
\text { employees } \\
\text { 3.2 Human capital and } \\
\text { innovation: } \\
\text { - dummy for product/process } \\
\text { innovation } \\
\text { 3.3 Financial: } \\
\text { none }\end{array}$ & $\begin{array}{l}\text { 4.1 Data: } \\
\text { - Type: manufacturing sector, } \\
\text { single-country analysis } \\
\text { - Source: Mediocredito } \\
\text { Centrale (1989-1991; 1992- } \\
\text { 1994; 1995-1997) } \\
\text { 4.2 Empirical strategy: } \\
\text { - Econometric analysis: } \\
\text { regressions (panel: Seemingly } \\
\text { Unrelated Regression) }\end{array}$ & $\begin{array}{l}\text { 5.1 Direction: } \\
\text { - learning-by- } \\
\text { internationalisation } \\
5.2 \text { Econometric tools: } \\
\text { none }\end{array}$ & $\begin{array}{l}\text { 6.1 Common patterns } \\
\text { Labour market } \\
6.2 \text { Degree of } \\
\text { internationalisation: } \\
\text { none } \\
\text { 6.3 Performance } \\
\text { premiums/discounts: } \\
\text { The increased demand for } \\
\text { skilled workers relates to } \\
\text { organisational changes rather } \\
\text { than innovation and FDI. }\end{array}$ \\
\hline $\begin{array}{l}\text { Razzolini and } \\
\text { Vannoni (2009, } \\
2011)\end{array}$ & $\begin{array}{l}\text { 2.1 Categories of } \\
\text { international involvement: } \\
\text { - export (status) } \\
\text { - subcontracting (status) } \\
\text { 2.2 Comparison strategy: } \\
\text { One variable for each category, } \\
\text { to compare international } \\
\text { enterprises with themselves } \\
\text { and with domestic players. }\end{array}$ & $\begin{array}{l}\text { 3.1 Economic: } \\
\text { - productivity (labour } \\
\text { productivity; TFP) } \\
\text { 3.2 Human capital and } \\
\text { innovation: } \\
\text { none } \\
\text { 3.3 Financial: } \\
\text { none }\end{array}$ & $\begin{array}{l}\text { 4.1 Data: } \\
\text { - Type: manufacturing sector, } \\
\text { single-country analysis } \\
\text { - Source: Capitalia (1998-2000; } \\
\text { 2001-2003) } \\
\text { 4.2 Empirical strategy: } \\
\text { - Descriptive statistics } \\
\text { - Econometric analysis: } \\
\text { regressions (panel: Pooled } \\
\text { OLS); non parametric analysis } \\
\text { (Kolmogorov-Smirnov, Fligner- }\end{array}$ & $\begin{array}{l}\text { 5.1 Direction: } \\
\text { - learning-by- } \\
\text { internationalisation } \\
5.2 \text { Econometric tools: } \\
\text { none }\end{array}$ & $\begin{array}{l}\text { 6.1 Common patterns } \\
\text { Not only export } \\
\text { 6.2 Degree of } \\
\text { internationalisation: } \\
\text { Exporters are the majority, and } \\
\text { many of them are also } \\
\text { subcontractors. } \\
\text { 6.3 Performance } \\
\text { premiums/discounts: } \\
\text { Exporters are more productive } \\
\text { than non-exporters. }\end{array}$ \\
\hline
\end{tabular}




\begin{tabular}{|c|c|c|c|c|c|}
\hline & & & Policello) & & $\begin{array}{l}\text { Subcontractors are less } \\
\text { productive than non- } \\
\text { subcontractors. }\end{array}$ \\
\hline Secchi et al. (2013) & $\begin{array}{l}\text { 2.1 Categories of } \\
\text { international involvement: } \\
\text { - export (value) } \\
\text { 2.2 Comparison strategy: } \\
\text { One variable for each category, } \\
\text { to compare international } \\
\text { enterprises with themselves } \\
\text { and with domestic players. }\end{array}$ & $\begin{array}{l}\text { 3.1 Economic: } \\
\text { - productivity (TFP) } \\
\text { - size (employees) } \\
\text { - age } \\
\text { - capital } \\
\text { - gross operating margin } \\
\text { 3.2 Human capital and } \\
\text { innovation: } \\
\text { - none } \\
\text { 3.3 Financial: } \\
\text { - credit rating index }\end{array}$ & $\begin{array}{l}\text { 4.1 Data: } \\
\text { - Type: manufacturing sector, } \\
\text { single-country analysis } \\
\text { - Source: ASIA + COE + } \\
\text { Centrale dei Bilanci (2000- } \\
2003 \\
\text { - Econometric analysis: } \\
\text { regressions (panel: OLS, fixed } \\
\text { effects, 2SLS, Probit, } \\
\text { Instrumental Variables) }\end{array}$ & $\begin{array}{l}\text { 5.1 Direction: } \\
\text { - self-selection } \\
\text { 5.2 Econometric tools: } \\
\text { - lagged variables }\end{array}$ & $\begin{array}{l}\text { 6.1 Common patterns } \\
\text { Financial market } \\
\text { 6.2 Degree of } \\
\text { internationalisation: } \\
\text { none } \\
6.3 \text { Performance } \\
\text { premiums/discounts: } \\
\text { Exporters are larger, older, } \\
\text { more productive, more capital } \\
\text { intensive and less financially } \\
\text { constrained than non-exporters. } \\
\text { Moreover, constrained firms } \\
\text { charge higher prices than } \\
\text { unconstrained firms exporting } \\
\text { the same product to the same } \\
\text { market. }\end{array}$ \\
\hline Secchi et al. (2014) & $\begin{array}{l}\text { 2.1 Categories of } \\
\text { international involvement: } \\
\text { - export (number of } \\
\text { destinations; number of } \\
\text { exported goods; dummy for } \\
\text { country dropping; dummy for } \\
\text { product dropping; share of } \\
\text { foreign sales from dropped } \\
\text { countries; share of foreign } \\
\text { sales from dropped products) } \\
2.2 \text { Comparison strategy: } \\
\text { One variable for each category, } \\
\text { to compare international } \\
\text { enterprises with themselves } \\
\text { and with domestic players. }\end{array}$ & $\begin{array}{l}\text { 3.1 Economic: } \\
\text { - productivity (TFP) } \\
\text { - size (employees) } \\
\text { - age } \\
\text { - capital } \\
\text { - gross operating margin } \\
\text { 3.2 Human capital and } \\
\text { innovation: } \\
\text { - none } \\
\text { 3.3 Financial: } \\
\text { - credit rating index }\end{array}$ & $\begin{array}{l}\text { 4.1 Data: } \\
\text { - Type: manufacturing sector, } \\
\text { single-country analysis } \\
\text { - Source: COE + Centrale dei } \\
\text { Bilanci (2000-2003 } \\
\text { - Econometric analysis: } \\
\text { regressions (cross-section: } \\
\text { Pooled OLS; Pooled Probit); } \\
\text { non parametric analysis } \\
\text { (Fligner-Policello) }\end{array}$ & $\begin{array}{l}\text { 5.1 Direction: } \\
\text { - self-selection } \\
\text { 5.2 Econometric tools: } \\
\text { - lagged variables }\end{array}$ & $\begin{array}{l}\text { 6.1 Common patterns } \\
\text { Financial market } \\
\text { 6.2 Degree of } \\
\text { internationalisation: } \\
\text { none } \\
\text { 6.3 Performance } \\
\text { premiums/discounts: } \\
\text { Financial constraints are } \\
\text { correlated with worse export } \\
\text { performance. Indeed, financially } \\
\text { constrained firms export a lower } \\
\text { number of goods to a lower } \\
\text { number of destinations; they } \\
\text { have a higher probability to drop } \\
\text { goods and destinations; they } \\
\text { tend to drop relatively better } \\
\text { goods and destinations and } \\
\text { have a higher loss of export } \\
\text { value associated with dropping } \\
\text { goods or destinations than } \\
\text { unconstrained firms. }\end{array}$ \\
\hline $\begin{array}{l}\text { Serti and Tomasi } \\
\text { (2008a) }\end{array}$ & $\begin{array}{l}\text { 2.1 Categories of } \\
\text { international involvement: } \\
\text { - export (n. of exporters; value; } \\
\text { intensity; status) } \\
\text { 2.2 Comparison strategy: } \\
\text { One variable for each category, } \\
\text { to compare international } \\
\text { enterprises with themselves } \\
\text { and with domestic players. }\end{array}$ & $\begin{array}{l}\text { 3.1 Economic: } \\
\text { - productivity (labour } \\
\text { productivity, TFP) } \\
\text { - size (employees, sales) } \\
\text { - capital } \\
\text { - capital intensity } \\
\text { - wage } \\
\text { 3.2 Human capital and } \\
\text { innovation: }\end{array}$ & $\begin{array}{l}\text { 4.1 Data: } \\
\text { - Type: manufacturing sector, } \\
\text { single-country analysis } \\
\text { - Source: Micro1 (1989-1997) + } \\
\text { COE (1993-1997) } \\
\text { 4.2 Empirical strategy: } \\
\text { - Econometric analysis: } \\
\text { regressions (panel: Pooled } \\
\text { OLS; PSM) }\end{array}$ & $\begin{array}{l}\text { 5.1 Direction: } \\
\text { - self-selection } \\
\text { - learning-by- } \\
\text { internationalisation } \\
\text { 5.2 Econometric tools: } \\
\text { - explicit test for causality } \\
\text { (PSM with internationalisation } \\
\text { in the treatment; support to } \\
\text { both hypothesis) }\end{array}$ & $\begin{array}{l}\text { 6.1 Common patterns } \\
\text { Causal links between export } \\
\text { and productivity } \\
6.2 \text { Degree of } \\
\text { internationalisation: } \\
\text { none } \\
6.3 \text { Performance } \\
\text { premiums/discounts: } \\
\text { There exists a positive }\end{array}$ \\
\hline
\end{tabular}




\begin{tabular}{|c|c|c|c|c|c|}
\hline & & $\begin{array}{l}\text { - share of white collar } \\
\text { employees } \\
\text { 3.3 Financial: } \\
\text { none }\end{array}$ & & & $\begin{array}{l}\text { correlation between export and } \\
\text { all performance indicators. }\end{array}$ \\
\hline $\begin{array}{l}\text { Serti and Tomasi } \\
(2008 b)\end{array}$ & $\begin{array}{l}\text { 2.1 Categories of } \\
\text { international involvement: } \\
\text { - export (status; status of } \\
\text { exporters to EU; status of } \\
\text { exporters to High-Medium } \\
\text { Income Countries; status of } \\
\text { exporters to Low-income } \\
\text { Countries; status of exporters } \\
\text { to more than one area) } \\
\text { - import (status; status of } \\
\text { importers from EU; status of } \\
\text { importers from High-Medium } \\
\text { Income Countries; status of } \\
\text { importers from Low-income } \\
\text { Countries; status of importers } \\
\text { from more than one area) } \\
\text { - two-way trading (status) } \\
\text { 2.2 Comparison strategy: } \\
\text { One variable for each category, } \\
\text { to compare international } \\
\text { enterprises with themselves } \\
\text { and with domestic players. }\end{array}$ & $\begin{array}{l}\text { 3.1 Economic: } \\
\text { - productivity (labour } \\
\text { productivity, TFP) } \\
\text { - size (employees, sales) } \\
\text { - capital intensity } \\
\text { 3.2 Human capital and } \\
\text { innovation: } \\
\text { - share of white collar } \\
\text { employees } \\
\text { 3.3 Financial: } \\
\text { none }\end{array}$ & $\begin{array}{l}\text { 4.1 Data: } \\
\text { - Type: manufacturing sector, } \\
\text { single-country analysis } \\
\text { - Source: Micro1 (1989-1997) + } \\
\text { COE (1993-1997) } \\
\text { 4.2 Empirical strategy: } \\
\text { - Descriptive statistics } \\
\text { - Econometric analysis: } \\
\text { regressions (panel: Pooled } \\
\text { OLS, fixed effects) }\end{array}$ & $\begin{array}{l}\text { 5.1 Direction: } \\
\text { - learning-by- } \\
\text { internationalisation } \\
5.2 \text { Econometric tools: } \\
\text { none }\end{array}$ & $\begin{array}{l}\text { 6.1 Common patterns } \\
\text { The import-export nexus } \\
6.2 \text { Degree of } \\
\text { internationalisation: } \\
\text { Traders are the majority (75\%) } \\
\text { and many of them (65\%) are } \\
\text { two-way traders. Moreover, } \\
\text { trade is more concentrated in } \\
\text { high-income, large and nearby } \\
\text { destinations. } \\
6.3 \text { Performance } \\
\text { premiums/discounts: } \\
\text { Two-way traders are better than } \\
\text { importers which, in turn, are } \\
\text { better than exporters, in term of } \\
\text { all performance indicators. } \\
\text { Moreover, trade premiums are } \\
\text { market specific. } \\
\text { Firms trading in more } \\
\text { geographical areas are the best } \\
\text { performing. } \\
\text { Among exporters, those selling } \\
\text { outside the EU are the best } \\
\text { performing; the opposite is true } \\
\text { for importers. }\end{array}$ \\
\hline Serti et al. (2010) & $\begin{array}{l}\text { 2.1 Categories of } \\
\text { international involvement: } \\
\text { - export (status; status of "big } \\
\text { exporters", i.e., firms exporting } \\
\text { more than } 50 \%, 70 \%, 90 \% \text { of } \\
\text { sales to EU, High-Medium } \\
\text { Income Countries, Low-income } \\
\text { Countries, more than one area) } \\
\text { - import (status; status of "big } \\
\text { importers", i.e., firms importing } \\
\text { more than 50\%, 70\%, 90\% of } \\
\text { sales from EU, High-Medium } \\
\text { Income Countries, Low-income } \\
\text { Countries, more than one area) } \\
\text { - two-way trading (status) } \\
\text { 2.2 Comparison strategy: } \\
\text { One variable for each category, } \\
\text { to compare international } \\
\text { enterprises with themselves } \\
\text { and with domestic players. }\end{array}$ & $\begin{array}{l}\text { 3.1 Economic: } \\
\text { - wage } \\
\text { - wage of blue collar } \\
\text { employees } \\
\text { - wage of white collar } \\
\text { employees } \\
\text { 3.2 Human capital and } \\
\text { innovation: } \\
\text { - share of white collar } \\
\text { employees } \\
\text { 3.3 Financial: } \\
\text { none }\end{array}$ & $\begin{array}{l}\text { 4.1 Data: } \\
\text { - Type: manufacturing sector, } \\
\text { single-country analysis } \\
\text { - Source: Micro1 (1989-1997) + } \\
\text { COE (1993-1997) } \\
\text { 4.2 Empirical strategy: } \\
\text { - Econometric analysis: } \\
\text { regressions (panel: OLS) }\end{array}$ & $\begin{array}{l}\text { 5.1 Direction: } \\
\text { - learning-by- } \\
\text { internationalisation } \\
5.2 \text { Econometric tools: } \\
\text { none }\end{array}$ & $\begin{array}{l}\text { 6.1 Common patterns } \\
\text { Labour market } \\
6.2 \text { Degree of } \\
\text { internationalisation: } \\
\text { Traders are the majority. In } \\
\text { particular, exporters account for } \\
67 \% \text {, importers for } 62 \% \text { and } \\
\text { two-way traders for } 56 \% \text {. } \\
6.3 \text { Performance } \\
\text { premiums/discounts: } \\
\text { Two-way traders are better than } \\
\text { importers which, in turn, are } \\
\text { better than exporters, in term of } \\
\text { wage and skill premiums. } \\
\text { Firms exporting to/importing } \\
\text { from more distant markets } \\
\text { exhibit larger wage and } \\
\text { productivity premiums. }\end{array}$ \\
\hline
\end{tabular}




\begin{tabular}{|c|c|c|c|c|c|}
\hline \begin{tabular}{|l} 
Serti and Tomasi \\
(2012)
\end{tabular} & $\begin{array}{l}\text { 2.1 Categories of } \\
\text { international involvement: } \\
\text { - export (status; status of "big } \\
\text { exporters", i.e., firms exporting } \\
\text { more than } 50 \%, 70 \%, 90 \% \text { of } \\
\text { sales to EU, High-Medium } \\
\text { Income Countries, Low-income } \\
\text { Countries, more than one area) } \\
\text { - import (status; status of "big } \\
\text { importers", i.e., firms importing } \\
\text { more than 50\%, 70\%, 90\% of } \\
\text { sales from EU, High-Medium } \\
\text { Income Countries, Low-income } \\
\text { Countries, more than one area) } \\
\text { - two-way trading (status) } \\
\text { 2.2 Comparison strategy: } \\
\text { One variable for each category, } \\
\text { to compare international } \\
\text { enterprises with themselves } \\
\text { and with domestic players. }\end{array}$ & $\begin{array}{l}\text { 3.1 Economic: } \\
\text { - productivity (labour } \\
\text { productivity, TFP) } \\
\text { - size (employees) } \\
\text { - capital intensity } \\
\text { 3.2 Human capital and } \\
\text { innovation: } \\
\text { - share of white collar } \\
\text { employees } \\
\text { 3.3 Financial: } \\
\text { none }\end{array}$ & $\begin{array}{l}\text { 4.1 Data: } \\
\text { - Type: manufacturing sector, } \\
\text { single-country analysis } \\
\text { - Source: Micro1 (1989-1997) + } \\
\text { COE (1993-1997) } \\
\text { 4.2 Empirical strategy: } \\
\text { - Descriptive statistics } \\
\text { - Econometric analysis: } \\
\text { regressions (panel: Pooled } \\
\text { OLS) }\end{array}$ & $\begin{array}{l}\text { 5.1 Direction: } \\
\text { - self-selection } \\
\text { 5.2 Econometric tools: } \\
\text { - explicit test for causality } \\
\text { (Bernard and Jensen } \\
\text { methodology) }\end{array}$ & $\begin{array}{l}\text { 6.1 Common patterns } \\
\text { The import-export nexus } \\
\text { 6.2 Degree of } \\
\text { internationalisation: } \\
\text { Traders are the majority (75\%) } \\
\text { and many of them are two-way } \\
\text { traders. Moreover, trade is more } \\
\text { concentrated in the EU and } \\
\text { High-Medium Income Countries } \\
6.3 \text { Performance } \\
\text { premiums/discounts: } \\
\text { Two-way traders are better than } \\
\text { importers which, in turn, are } \\
\text { better than exporters, in term of } \\
\text { all performance indicators. } \\
\text { Moreover, trade premiums are } \\
\text { market specific, and they } \\
\text { depend on some } \\
\text { macroeconomic variables such } \\
\text { as geographical distance and } \\
\text { the level of development. }\end{array}$ \\
\hline Sterlacchini (1999) & $\begin{array}{l}\text { 2.1 Categories of } \\
\text { international involvement: } \\
\text { - export (status; intensity) } \\
\text { 2.2 Comparison strategy: } \\
\text { One variable for each category, } \\
\text { to compare international } \\
\text { enterprises with themselves } \\
\text { and with domestic players. }\end{array}$ & $\begin{array}{l}\text { 3.1 Economic: } \\
\text { - size (sales) } \\
\text { 3.2 Human capital and } \\
\text { innovation: } \\
\text { - share of innovation costs due } \\
\text { to purchase of innovation } \\
\text { capital } \\
\text { - share of innovation costs due } \\
\text { to purchase of engineering and } \\
\text { pre-product development } \\
\text { - level of automation of the } \\
\text { production process } \\
\text { 3.3 Financial: } \\
\text { none }\end{array}$ & $\begin{array}{l}\text { 4.1 Data: } \\
\text { - Type: manufacturing sector, } \\
\text { single-country analysis } \\
\text { - Source: Indagine Regione } \\
\text { Marche (1994-1996) } \\
\text { 4.2 Empirical strategy: } \\
\text { - Descriptive statistics } \\
\text { - Econometric analysis: } \\
\text { regressions (cross-section: } \\
\text { Probit, Tobit) }\end{array}$ & $\begin{array}{l}\text { 5.1 Direction: } \\
\text { - self-selection } \\
\text { 5.2 Econometric tools: } \\
\text { none }\end{array}$ & $\begin{array}{l}\text { 6.1 Common patterns } \\
\text { Innovation } \\
6.2 \text { Degree of } \\
\text { internationalisation: } \\
\text { none } \\
6.3 \text { Performance } \\
\text { premiums/discounts: } \\
\text { Small firms belonging to non } \\
\text { high-tech intensive sectors } \\
\text { innovate a lot. This innovative } \\
\text { activity is positively correlated } \\
\text { with export intensity, while } \\
\text { export probability is increasing } \\
\text { in size. }\end{array}$ \\
\hline \begin{tabular}{|l|} 
Sterlacchini (2001) \\
\end{tabular} & $\begin{array}{l}\text { 2.1 Categories of } \\
\text { international involvement: } \\
\text { - export (status; intensity) } \\
2.2 \text { Comparison strategy: } \\
\text { One variable for each category, } \\
\text { to compare international } \\
\text { enterprises with themselves } \\
\text { and with domestic players. }\end{array}$ & $\begin{array}{l}\text { 3.1 Economic: } \\
\text { - size (sales) } \\
\text { 3.2 Human capital and } \\
\text { innovation: } \\
\text { - share of R\&D personnel } \\
\text { - dummy for product/process } \\
\text { innovation } \\
\text { 3.3 Financial: } \\
\text { none }\end{array}$ & $\begin{array}{l}\text { 4.1 Data: } \\
\text { - Type: manufacturing sector, } \\
\text { single-country analysis } \\
\text { - Source: Mediocredito } \\
\text { Centrale (1989-1991) } \\
\text { 4.2 Empirical strategy: } \\
\text { - Descriptive statistics } \\
\text { - Econometric analysis: } \\
\text { regressions (cross-section: } \\
\text { Probit, Tobit) }\end{array}$ & $\begin{array}{l}\text { 5.1 Direction: } \\
\text { - self-selection } \\
\text { 5.2 Econometric tools: } \\
\text { - lagged variables }\end{array}$ & $\begin{array}{l}\text { 6.1 Common patterns } \\
\text { Innovation } \\
6.2 \text { Degree of } \\
\text { internationalisation: } \\
\text { none } \\
6.3 \text { Performance } \\
\text { premiums/discounts: } \\
\text { There exists a positive } \\
\text { correlation between size and } \\
\text { export only for small firms. } \\
\text { For small firms, export is } \\
\text { positively correlated with } \\
\text { process innovation; for medium } \\
\text { enterprises, export is positively }\end{array}$ \\
\hline
\end{tabular}




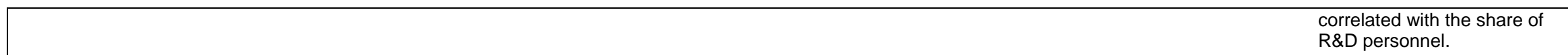




\section{References}

Accetturo, A., Bugamelli, M. and Lamorgese, A.R. (2013) Skill Upgrading and Exports, in Economics Letters 121: 417-420.

Aristei, D. and Franco, C. (2014) The role of credit constraints on firms' exporting and importing activities. Industrial and Corporate Change 30: 1493-1522.

Aristei, D., Castellani, D. and Franco, C. (2013) Firms' Exporting and Importing Activities: Is there a Two-Way Relationship?. Review of World Economics 149: 55-84.

Ariu, A. (2014) Services versus Goods Trade: Are They the Same?. National Bank of Belgium Working Paper, No. 237.

Aw, B. and Lee, Y. (2008) Firm Heterogeneity and Location Choice for Taiwanese Multinationals. Journal of International Economics 75: 67-179.

Aw, B.J., Roberts, M.J. and Xu, D.Y. (2011) R\&D investment, exporting, and productivity dynamics. American Economic Review 101: 1312-1344.

Baldwin, J. and Gu, W. (2009) The impact of trade on plant scale, production-run length and diversification. In T. Dunne, J.B. Jensen and M.J. Roberts (eds.) Producer Dynamics: New Evidence from Micro Data, pp. 557-595. Chicago:University of Chicago Press.

Barba Navaretti, G., Bugamelli, M., Faini, R., Schivardi, F. and Tucci, A. (2007) Le imprese e la specializzazione produttiva dell'Italia. Dal macrodeclino alla microcrescita?. In R. Baldwin, G. Barba Navaretti and T. Boeri (eds.) Come sta cambiando l'Italia. Le trasformazioni della struttura produttiva e i costi sociali del cambiamento. Bologna: Il Mulino.

Barba Navaretti, G., Basile, R., Benfratello, L., Castellani, D., Cerisola, S. and Salvi, A. (2008) Le imprese e il mercato internazionale: quali prospettive per il Mezzogiorno italiano?. Luca D’Agliano Policy Report: 1.

Barba Navaretti, G., Bugamelli, M., Schivardi, F., Altomonte, C., Horgos, D. and Maggioni, D. (2011) The Global Operations of European Firms, Second EFIFE Policy Report, Bruegel: 12.

Barba Navaretti, G., Bugamelli, M., Cristadoro, R. and Maggioni, D. (2012) Do Firms Exporting to China and India Look Different?, Bank of Italy Occasional Papers, Questioni di Economia e Finanza: 112.

Basile, R. (2001a) Export Behaviour of Italian Manufacturing Firms over the Nineties: The Role of Innovation. Research Policy 30: 1185-1201.

(2001b) Innovazione e propensione ad esportare delle imprese italiane e ruolo del Mezzogiorno, in B. Quintieri (ed), Le imprese esportatrici italiane: caratteristiche, performance e internazionalizzazione, Bologna, Il Mulino. 
Basile, R., Giunta, A. and Nugent, J.B. (2003) Foreign Expansion by Italian Manufacturing Firms in the Nineties: an Ordered Probit Analysis. Review of Industrial Organization 23: 124.

Basile, R., De Nardi, S. and Girardi A. (2012) Pricing to Market, Firm Heterogeneity and the Role of Quality. Review of World Economics 148: 595-615.

Becchetti, L. and Rossi, S.P.S. (2000) The Positive Effect of Industrial District on the Export Performance of Italian Firms. Review of Industrial Organization 16: 53-68.

Becchetti, L. and Gonzales, J.H.S. (2001) Struttura proprietaria e accesso ai mercati esteri delle piccole e medie imprese italiane. In B. Quintieri (ed.) Le imprese esportatrici italiane: caratteristiche, performance e internazionalizzazione. Bologna: Il Mulino.

Becchetti, L., De Panizza, A. and Oropallo, F. (2010) Role of Industrial District Externalities in Export and Value Added Performance: Evidence from the Population of Italian Firms. Regional Studies 41: 601-621.

Becker, S. and Ichino, A. (2002) Estimation of Treatment Effects Based on Propensity Score. The Stata Journal 2: 358-377.

Bell, M. and Pavitt, K. (1993) Accumulating Technological Capability in Developing Countries. World Bank Economic Review supplement: 257-281.

Benfratello, L. and Razzolini, T. (2009) Firms' Productivity and Internationalisation Choices: Evidence from a Large Sample of Italian Firms. In L. Piscitello and G. Santangelo (eds.) Multinationals and local competitiveness. Milano: Franco Angeli.

Benfratello, L., Razzolini, T. and Sembenelli, A. (2009) Does ICT Investment Spur or Hamper Offshoring?. Empirical Evidence from Microdata, Department of Economics and Public Finance “G. Prato” Working Paper Series: 5.

Benfratello, L., Bottasso, A. and Piccardo, C. (2014) Innovative capacity and export performance: Exploring heterogeneity along the export intensity distribution. CSEF Working Paper: 371.

Bernard, A.B. and Jensen, J.B. (1995) Exporters, Jobs and Wages in US manufacturing: 19761987. Brookings Papers on Economic Activity, Microeconomics, pp. 67-119.

Bernard, A.B., Eaton, J., Jensen, J.B. and Kortum, S. (2003) Plants and Productivity in International Trade. American Economic Review 93: 1268-1290.

Bernard, A.B., Redding, S. and Schott, P. (2007) Comparative advantage and Heterogeneous Firms. Review of Economic Studies 74: 31-66.

$70-97$.

(2010) Multi-product Firms and Product Switching. American Economic Review 100: 
Bernard, A.B., Grazzi, M. and Tomasi, C. (2010) Intermediaries in International Trade: Direct versus Indirect Modes of Export. National Bank of Belgium Working Paper: 199.

Bernini, M. and Tomasi, C. (2014) Exchange rate pass-through and product heterogeneity: Does quality matter on the import side?. The University of Sheffield, Department of Economics Working Paper 20.

Bonaccorsi, A. (1992) On the Relationship between Firms Size and Export Intensity. Journal of International Business Studies 23: 605-635.

Bottasso, A. and Piccardo, C. (2013) Export Activity and Firm Heterogeneity: A Survey of the Empirical Evidence for Italy. Journal of Industrial and Business Economics 40: 27-61.

Bratti, M. and Felice, G. (2012) Are exporters more likely to introduce product innovation?. The World Economy 35: 1559-1598.

Breinlich, H. and Criscuolo, C. (2011) International Trade in Services: A Portrait of Importers and Exporters. Journal of International Economics 84: 188-206.

Bugamelli, M. (2007) Export prices, product quality and firms' characteristics: An analysis on a sample of Italian firms. Bank of Italy, Economic Research and International relations Area, Economic Working Paper: 634.

Bugamelli, M., Cipollone, P. and Infante, L. (2000) L’internazionalizzazione delle imprese italiane negli anni novanta. Rivista Italiana degli Economisti 3: 349-386.

-------- (2001) Le imprese italiane all'estero: una valutazione quantitativa per strategia di accesso. In B. Quintieri (ed.) Le imprese esportatrici italiane: caratteristiche, performance e internazionalizzazione. Bologna: Il Mulino.

Bugamelli, M. and Infante, L. (2003) Sunk Costs to Exports. Bank of Italy, Economic Research and International relations Area, Economic Working Paper: 469.

Bugamelli, M. and Tedeschi, R. (2007) Exporters' pricing strategies: The case of Italy. Politica economica 3: 321-350.

Bugamelli, M. and Tedeschi, R. (2008) Pricing-to-market and market structure. Oxford Bulletin of Economics and Statistics 70: 155-180.

Bugamelli, M., Fabiani, S. and Sette, E. (2010) The pro-competitive effect of imports from China: ana analysis of firm-level price data. Bank of Italy, Economic Research and International relations Area, Economic Working Paper: 737.

Bugamelli, M. and Gallo, M. (2012) The big exporters in Italy: Characteristics, strategies and performance. Journal of Industrial and Business Economics 39: 119-137. 
Bustos, P. (2011) Trade Liberalization, Exports and Technology Upgrading: Evidence on the Impact of MERCOSUR on Argentinean firms. American Economic Review 101: 304-340.

Caliendo, M. and Hujer, R. (2006) The Microeconometric Estimation of Treatment Effects. An Overview. Allgemeines Statistiches Archiv 90: 197-2012.

Caliendo, M. and Kopeinig, S. (2008) Some Practical Guidance for the Implementation of the Propensity Score Matching. Journal of Economic Surveys 22: 31-72.

Campanini, L. and Falzoni, A.M. (2001) Pmi ed attività esportativa: mercati, prodotti e caratteristiche d'impresa, in B. Quintieri (ed), Le imprese esportatrici italiane: caratteristiche, performance e internazionalizzazione, Bologna, Il Mulino.

Casaburi, L., Gattai V. and Minerva, G.A. (2007) Firms' International Status and Heterogeneity in Performance: Evidence From Italy. Rivista di Politica Economica special issue May-June: 151-187.

Castellani, D. (2002) Export Behaviour and Productivity Growth: Evidence from Italian Manufacturing Firms. Review of World Economics 138: 605-628.

(2007) L'internazionalizzazione della produzione in Italia: caratteristiche delle imprese ed effetti sul sistema economico. L'Industria 28: 467-493.

Castellani, D. and Zanfei, A. (2007) Internationalisation, Innovation and Productivity: How Do Firms Differ in Italy?. The World Economy 30: 156-176.

Castellani, D. and Giovannetti, G. (2008) Imprese internazionalizzate e produttività: il ruolo delle competenze organizzative e manageriali. l'Industria 29: 385-403.

(2010) Productivity and the International Firm: Dissecting Heterogeneity. Journal of Economic Policy Reform 13: 25-42.

Castellani, D., Serti, F. and Tomasi, C. (2010) Firms in International Trade: Importers and Exporters Heterogeneity in the Italian Manufacturing Industry. The World Economy 33: 424457.

Clerides, S.K., Lach, S. and Tybout, J.R. (1998), Is learning by exporting important? Microdynamic evidence from Colombia, Mexico and Morocco. Quarterly Journal of Economics 113: 903-947.

Conti, G., Lo Turco, A. and Maggioni, D. (2010a) Exporters in Services: New Evidence from Italian Firms. Applied Economic Quarterly 56: 73-98.

(2010b) Backward Linkages and the Export Performance of Business Services. Evidence from a Sample of Italian Firms. Dipartimento di Scienze Economiche e Sociali, Facoltà di Economia Giorgio Fuà, Università Politecnica delle Marche, Working Paper: 352. 
-------- (2013) Rethinking the Import-Productivity Nexus for Italian Manufacturing. Empirica, forthcoming.

Crinò, R. (2010) Employment Effects of Service Offshoring: Evidence from Matched Firms. Economics Letters 107: 253-256.

Crinò, R. and Epifani, P. (2012) Productivity, quality and export behaviour. The Economic Journal 122: 1206-1243.

D’Angelo, A. (2012) Innovation and Export Performance: A Study of Italian High-Tech SMEs. Journal of Management and Governance 14: 1-31.

De Angelis, E., De Nardis, S. and Pappalardo, C. (2011) Produttori ed esportatori multiprodotto, Rapporto ICE 2010-2011, ICE, published online.

Delgado, M.A., Farinas, J.C. and Ruano, S. (2002) Firm Productivity and Export Markets: a Nonparametric Approach. Journal of International Economics 57: 397-422.

De Nardis, S. and Pappalardo, C. (2009) Export, Productivity and Product Switching: The Case of Italian Manufacturing Firms, ISAE Working Papers: 110.

De Nardis, S. and Ventura, M. (2010) The Effects of Product Dropping on Firm's Productivity and Employment Composition. Empirical Economic Letters 9: 343-352.

Falvey, R., Greenaway, D. and Yu Z. (2004) Efficiency differentials and intra-industry trade. Leverhulme centre for Research on Globalisation and Economic Policy, University of Nottingham, GEP Research Paper: 05.

Federico, S. and Tosti, E. (2012) Exporters and Importers of Services: Firm-Level Evidence on Italy. Bank of Italy Economic Research and International Relations Area, Economic Working Papers: 877.

Ferragina, A. and Quintieri, B. (2001) Caratteristiche delle imprese esportatrici italiane in B. Quintieri (ed), Le imprese esportatrici italiane: caratteristiche, performance e internazionalizzazione, Bologna, Il Mulino.

Fontagne, L., Secchi, A. and Tomasi, C. (2014) Fickle product mix: Exporters adapting their product vectors across markets. Sant'Anna School of Adavnced Stduies, LEM Working Paper: 26.

Fligner, M.A. and Policello, G. (1981) Robust Rank Procedures for the Beherens-Fisher Problem. Journal of the American Statistical Association 76: 162-168.

Forlani, E. (2010) Liquidity Constraints and Firm's Export Activity. Centro Studi Luca d’Agliano Working Paper: 291.

Frazzoni, S., Mancusi, M.L., Rotondi Z., Sombrero M. and Vezzulli A. (2011) Relationship with Bancks and Access to Credit for Innovation and Internationalisation of SMEs. In Bracchi 
G. and D. Masciandaro (eds.) L'Europa e oltre. Banche e imprese nella nuova globalizzazione. Milano: Bancaria Editrice.

Giovannetti, G., Ricchiuti G. and Velucchi, M. (2009) Size, Innovation and Internationalisation: a Survival Analysis of Italian Firms. Applied Economics 1: 1-10.

-------- (2013) Heterogeneity in managerial strategies and internationalisation of firms: the case of Italy. Journal of Industrial and Business Economics 2: 51-66.

Giunta, A. and Scalera, D. (2007) L’impresa subfornitrice: redditività, produttività e divari territoriali. Journal of Industrial and Business Economics 3: 123-176.

Grazzi, M. (2012) Export and Firm Performance: Evidence on Productivity and Profitability of Italian Companies. Journal of Industry, Competition and Trade 12: 413-444.

Greenaway, D. and Kneller, R. (2007) Firm Heterogeneity, Exporting and Foreign Direct Investment: a Survey. The Economic Journal 117: F134-F161.

Hayakawa, K., Kimura, F., and Tomohiro Machikita. and Machikita, T. (2012) Globalization and Productivity: a Survey of Firm-Level Analysis. Journal of Economic Surveys 26: 332350.

Head, K. and Ries, J. (2003) Heterogeneity and the Foreign Direct Investment versus Exports Decision of Japanese Manufacturers. Journal of the Japanese and International Economics 17: 448-467.

Helpman, E., Melitz, M. and Yeaple, S. (2004) Export versus FDI. American Economic Review 94: 300-316.

Helpman, E. (2006) Trade, FDI, and the Organization of Firms. Journal of Economic Literature 44: 589-630.

ICE (2013) L'Italia nell'economia internazionale, Rapporto ICE 2012-2013, http://www.istat.it

Imbens, G.W. and Wooldridge, J.M. (2009) Recent Developments in the Econometrics of Program Evaluation. Journal of Economic Literature 47: 5-86.

Imbruno, M. (2008a) International Trade and Firm Productivity within the Italian Manufacturing Sector: Self-Selection or Learning-by-Exporting?. Università degli Studi di Foggia, Quaderni del Dipartimento di Scienze Economiche, Matematiche e Statistiche: 21.

(2008b) Exporting, Productivity and Market Integration: Italian Manufacturing Firms within the European Context. Università degli Studi di Foggia, Quaderni del Dipartimento di Scienze Economiche, Matematiche e Statistiche: 22.

ISGEP (2008) Understanding Cross-Country Differences in Exporter Premiums: Comparable Evidence from 14 Countries. Review of World Economics 144: 596-635. 
Jean, S. (2002) International Trade and Firms' Heterogeneity under Monopolistic Competition. Open Economics Review 13: 291-311.

Kelle, M. and Kleinert, J. (2010) German Firms in Service Trade. Kiel University, Department of Economics Working Paper: 3.

Lopez, R.A. (2005) Trade and Growth: Reconciling the Macroeconomic and Microeconomic Evidence. Journal of Economic Surveys 19: 623-648.

Lo Turco, A. and Maggioni, D. (2012) Offshoring to High and Low-income Countries and the Labor Demand. Evidence from Italian Firms. Review of International Economics 20: 636-653.

(2013) On the Role of Imports in Enhancing Manufacturing Exports. The World Economy 36: 93-120.

Lo Turco, A., Maggioni, D. and Picchio, M. (2013) Offshoring and Job Stability: Evidence from Italian Manufacturing. Structural Change and Economic Dynamics 26: 27-46.

Macis, M. and Schivardi, F. (2012) Export and Wages: Rent Sharing, Workforce Composition or Return to Skills?. EIFE Working Paper: 1205.

Manasse, P., and Stanca, L. (2006) Working on the train: trade, technology and wages in Italian manufacturing, Rivista di Politica Economica, 96: 279-308.

Manasse, P., Stanca, L. and Turrini, A. (2004) Wage premia and skill upgrading in Italy: why didn't the hound bark?. Labour Economics 11: 59-83.

Mayer, T. and Ottaviano, G.I.P. (2008) I pochi eletti: nuovi fatti sull'internazionalizzazione delle imprese europee. L'industria 29: 221-244.

Melitz, M.J. (2003) The impact of Trade on Intra-Industry Reallocations and Aggregate Industry Productivity. Econometrica 71: 1661-1694.

Melitz, M. and Ottaviano, G.I.P. (2008) Market Size, Trade and Productivity. Review of Economic Studies 75: 295-316.

Minetti, R. and Zhu, S.C. (2011) Credit Constraints and Firm Export: Microeconomic Evidence from Italy. Journal of International Economics 83: 109-125.

Morone, P., Renna F. and Testa, G. (2011) Innovation Activities and Firms' Future Exports Decisions: a Multi-Treatment Analysis. mimeo.

Nassimbeni, G. (2001) Technology, Innovation Capacity, and the Export Attitude of Small Manufacturing Firms: a Logit/Tobit Model. Research Policy 30: 245-262.

Pappalardo, C. and Vicarelli, C. (2012) Euro Introduction and Export Behaviour of Italian Firms. MPRA Working Paper: 3386. 
Pavcnik, N. (2002) Trade liberalization, exit, and productivity improvement: Evidence from Chilean plants. Review of Economic Studies 69: 245-276.

Raff, H., Ryan, M. and Stahler, F. (2008) Firm Productivity and the Foreign-Market Entry Decision. Economics Working Paper: 2.

Razzolini, T. and Vannoni, D. (2009) Strategie di export passive, produzione su commessa e performance. L'Industria 30: 437-465.

(2011) Export Premiums and Sub-contracting Discounts Passive Strategies and performance in Domestic and Foreign Markets. The World Economy 34: 984-1013.

Redding, S.J. (2011) Theories of Heterogeneous Firms and Trade. Annual Review of Economics 3: 77-105.

Secchi, A., Tamagni, F. and Tomasi, C. (2013) Export price adjustment under financial constraints, University of Pantheon-Sorbonne (Paris 1), Centre d'Economie de la Sorbonne Working Paper: 13057.

(2014) The micro patterns of export diversification under financial constraints. Sant'Anna School of Advanced Studies, LEM Working Paper: 17.

Serti, F. and Tomasi, C. (2008a) Self-Selection and Post-Entry Effects of Exports: Evidence from Italian Manufacturing Firms. Review of World Economics 144: 660-694.

------- (2008b) Firm Heterogeneity: Do Destinations of Exports and Origins of Imports Matter?. In L. Piscitello and G. Santangelo (eds.) Multinationals and local competitiveness. Milano: Franco Angeli.

-------- (2012) Self-Selection along Different Export and Import Markets. Economics Letters, 117: 102-105.

Serti, F., Tomasi, C. and Zanfei, A. (2010) Who Trades with Whom? Exploring the Links between Firm's International Activities, Skills and Wages. Review of International Economics 18: 951-971.

Sharpston, M. (1975) International Sub-Contracting. Oxford Economic Papers 27: 94-135.

Singh, T. (2010) Does International Trade Cause Economic Growth? A Survey. The World Economy 33: 1517-1564

Sterlacchini, A. (1999) Do Innovative Activities Matter to Small Firms in Non R\&DIntensive Industries? An Application to Export Performance. Research Policy 28: 819-832.

(2001) The Determinants of Export Performance: A Firm-Level Study of Italian Manufacturing. Review of World Economics 137: 450-472. 
Tybout, J. (2003) Plant- and Firm-Level Evidence on "New Trade Theories, in Choi K.E. and J. Harrigan (Eds), Handbook of International Trade, Oxford: Basil-Blackwell.

Van Biesebroeck, J. (2005) Exporting raises productivity in sub-Saharan African manufacturing firms. Journal of International Economics 67: 373-391.

Vivarelli, M. and Piva, M. (2001) The skill bias in Italy: A first report. Economics Bulletin 15: $1-8$.

Wagner, J. (2007) Exports and Productivity: A Survey of the Evidence from Firm-Level Data. The World Economy 30: 60-72.

(2012a) International Trade and Firm Performance: A Survey of Empirical Studies since 2006. Review of World Economics 148: 235-267.

(2012b) New Methods for the analysis of links between international firm activities and firm performance: A practitioner's guide. University of Luneburg, Institute of Economics Working Paper Series in Economics: 227.

Walter, P. and Dell'mour, R. (2010) Firm Level Analysis of International Trade in Services, IFC Working Paper, No. 4.

Yeaple, S.R. (2005) A Simple Model of Firm Heterogeneity, International Trade, and Wages. Journal of International Economics 65: 1-20. 